San Jose State University

SJSU ScholarWorks

Master's Theses

Master's Theses and Graduate Research

Fall 2009

\title{
Japanese bibliographic records and CJK cataloging in U.S. university libraries.
}

Mie Onnagawa

San Jose State University

Follow this and additional works at: https://scholarworks.sjsu.edu/etd_theses

\section{Recommended Citation}

Onnagawa, Mie, "Japanese bibliographic records and CJK cataloging in U.S. university libraries." (2009). Master's Theses. 4010.

DOI: https://doi.org/10.31979/etd.pcb8-mryq

https://scholarworks.sjsu.edu/etd_theses/4010

This Thesis is brought to you for free and open access by the Master's Theses and Graduate Research at SJSU ScholarWorks. It has been accepted for inclusion in Master's Theses by an authorized administrator of SJSU ScholarWorks. For more information, please contact scholarworks@sjsu.edu. 
JAPANESE BIBLIOGRAPHIC RECORDS AND

CJK CATALOGING IN U.S. UNIVERSITY LIBRARIES

\begin{abstract}
A Thesis
Presented to

The Faculty of the School of Library and Information Science

San José State University

In Partial Fulfillment

of the Requirements for the Degree

Master of Library and Information Science
\end{abstract}

by

Mie Onnagawa

December 2009 
UMI Number: 1484368

All rights reserved

INFORMATION TO ALL USERS

The quality of this reproduction is dependent upon the quality of the copy submitted.

In the unlikely event that the author did not send a complete manuscript and there are missing pages, these will be noted. Also, if material had to be removed, a note will indicate the deletion.

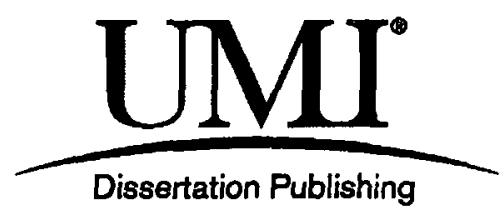

UM! 1484368

Copyright 2010 by ProQuest LLC.

All rights reserved. This edition of the work is protected against unauthorized copying under Title 17, United States Code.

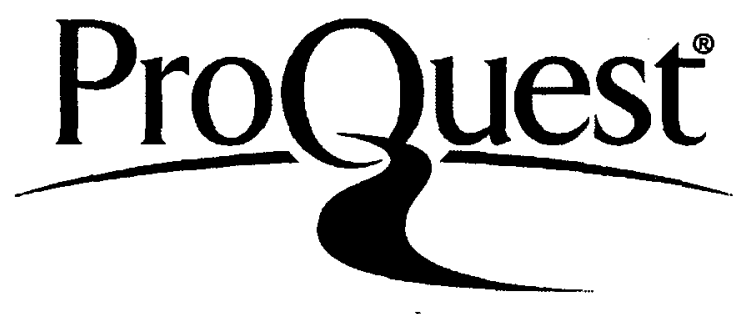

ProQuest LLC

789 East Eisenhower Parkway

P.O. Box 1346

Ann Arbor, Ml 48106-1346 
(C) 2009

Mie Onnagawa

ALL RIGHTS RESERVED 
SAN JOSE STATE UNIVERSITY

The Undersigned Thesis Committee Approves the Thesis Titled

JAPANESE BIBLIOGRAPHIC RECORDS AND

CJK CATALOGING IN USS. UNIVERSITY LIBRARIES

by

Me Onnagawa

APPROVED FOR THE SCHOOL OF LIBRARY AND INFORMATION SCIENCE
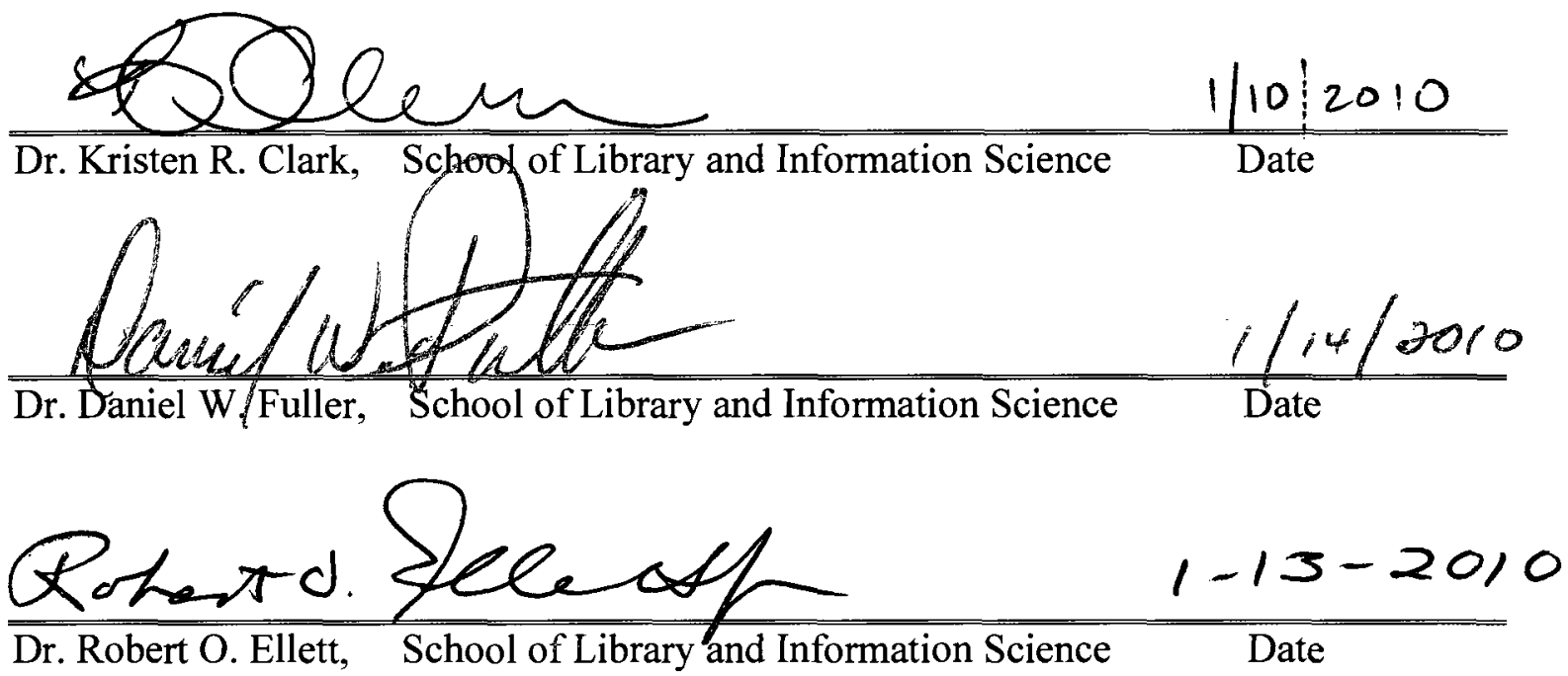

APPROVED FOR THE UNIVERSITY

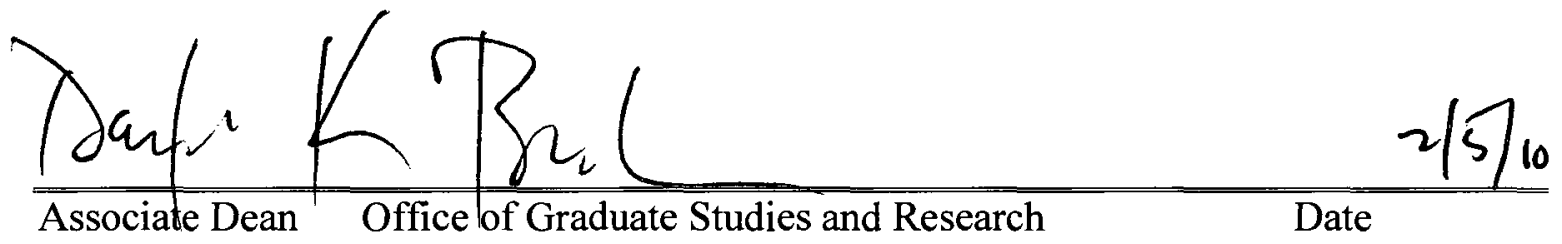




\section{ABSTRACT \\ JAPANESE BIBLIOGRAPHIC RECORDS AND \\ CJK CATALOGING IN U.S. UNIVERSITY LIBRARIES}

by Mie Onnagawa

In the last two decades, American university libraries have developed Chinese, Japanese, and Korean (CJK) enhancements to their library automation systems and transitioned from conventional card catalogs to online public access catalogs (OPAC) by using CJK vernacular scripts, although non-Roman script search options of these systems are still limited.

The East Asian library community in North America continues to deal with complex problems regarding the cataloging of East Asian library resources due to the inconsistency of cataloging rules used in bibliographic records for CJK materials. Despite all the improvements and efforts made by CJK catalogers, their task of creating more precise and accurate CJK library-cataloging records is still challenging, mainly due to unfamiliarity with cataloging rules and difficulties with language.

The purpose of this study is to examine the university library policies and practices in cataloging CJK materials and authority control of CJK bibliographic databases, particularly of Japanese records for monographs published after 1900s. The paper evaluates creating, maintaining, and sharing the bibliographic records for CJK materials. 


\section{ACKNOWLEDGMENTS}

There are many people from whom I have received much support to prepare for this study. I would like to thank all my families and friends both in Japan and the U.S. Many other individuals and institutions, including the university librarians who generously participated in my survey, have given of their time and effort in the preparation of this study. My three thesis committee members, Dr. Clark, Dr. Ellett, and Dr. Fuller, have patiently given their time reading and discussing my research with me, and provided some thoughtful comments and suggestions, within their limited busy time schedules. My appreciation is also extended to Mr. Irie and Ms. Sakemi of Keio University Library in Japan, who generously helped answer some questions, and provided some CJK cataloging related information.

Finally, I would like to express my deep appreciation to my fiancée Jeff Breidenbach, who has always patiently supported and encouraged me in many ways, without whom this study would not have been possible. 


\section{Table of Contents}

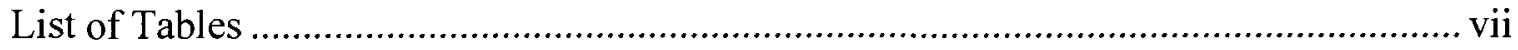

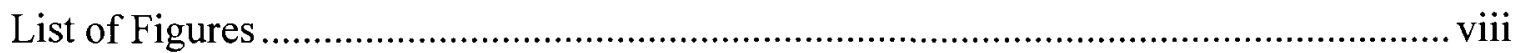

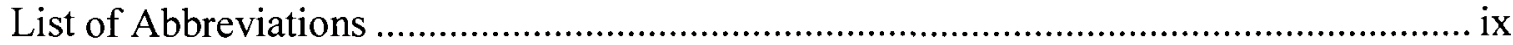

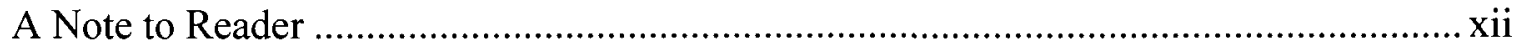

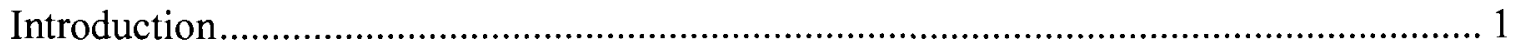

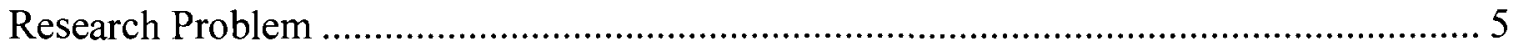

Statement of Major Research Questions ……………................................................ 5

Statement of Major Research Hypotheses................................................................. 6

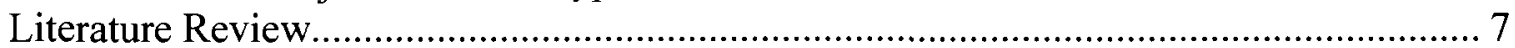

History and Background to the Problem ............................................................... 7

Japanese Writing System and its Romanization.......................................................... 16

Authority Control for CJK Cataloging System ………............................................. 19

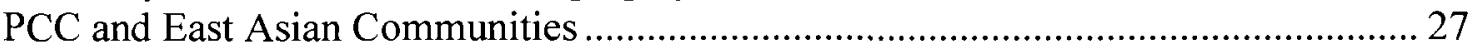

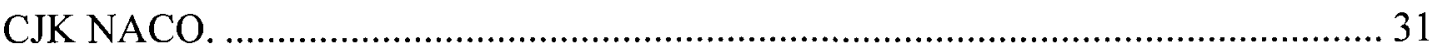

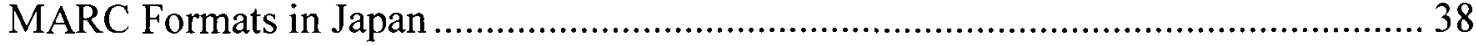

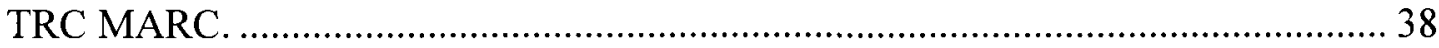

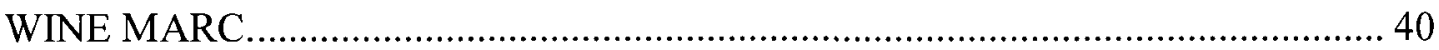

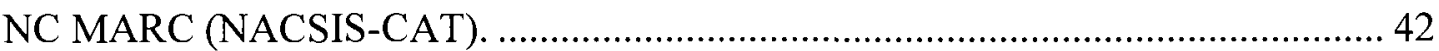

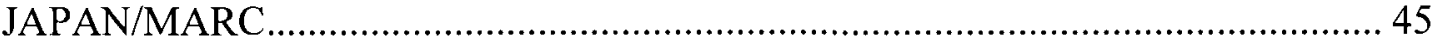

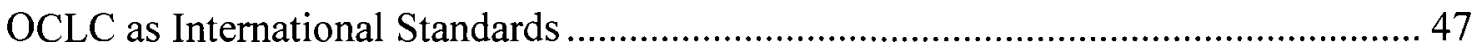

Issues of AACR2 and LCRI for CJK Cataloging..................................................... 55

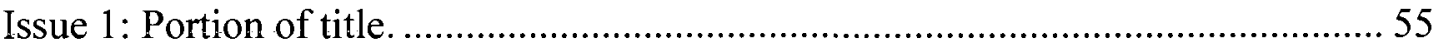

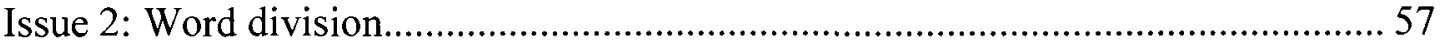

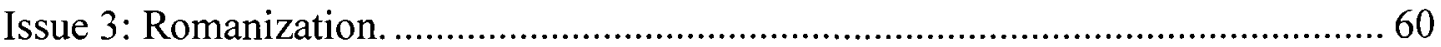

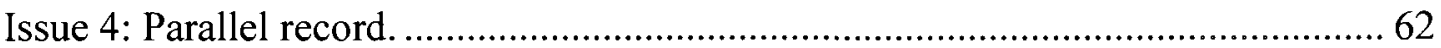

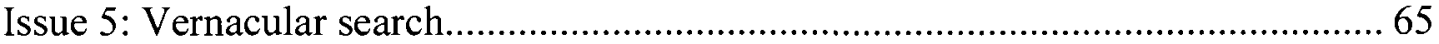

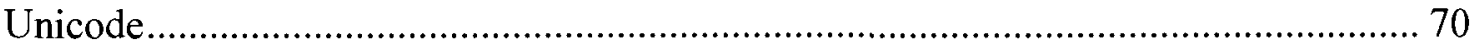

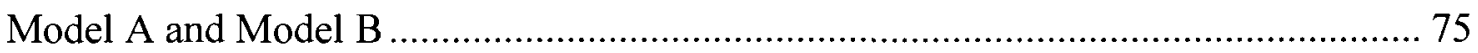

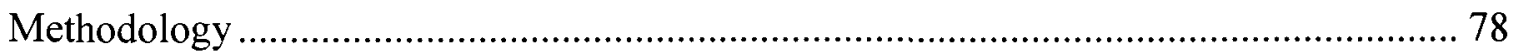

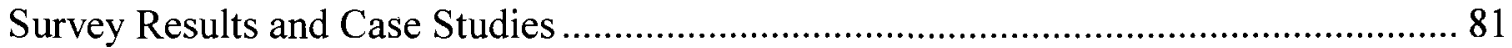

Collection Size, Cataloging Staff, PCC Participation, and Cataloging Feature ............ 81

Outsourced Cataloging and Copy-Cataloging ............................................................ 86

Backlogged CJK Library Materials ............................................................................ 92

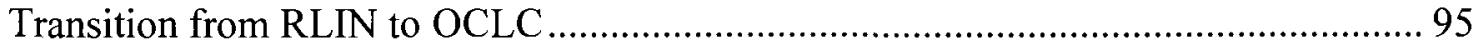

Maintenance and Update Bibliographic Records ...................................................... 98

Language Competency for Catalogers ………................................................. 100

Changes in Cataloging Practices ........................................................................ 105

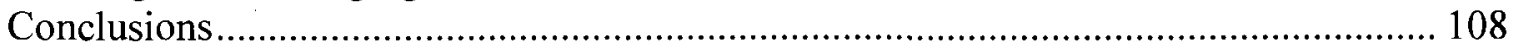

Future Issues and Recommendations............................................................... 110

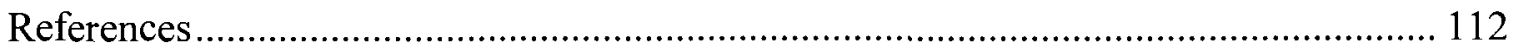

Appendix: Questionnaire on Cataloging for CJK Library Materials.............................. 123 


\section{List of Tables}

Table 1. OCLC Number of Bibliographic Records by Language (as of June 30, 2008) ..... 13

Table 2. NACO Funnel Projects (10/1/2008-3/31/2009) ............................................. 35

Table 3. CJK NACO Project (10/1/2007-3/31/2008)................................................. 36

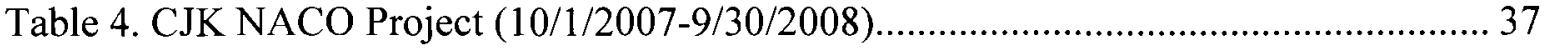

Table 5. CJK NACO Participants ......................................................................... 37

Table 6. Fields Used in TRC/MARC ...................................................................... 39

Table 7. Fields Used in NACSIS-CAT Catalog....................................................... 43

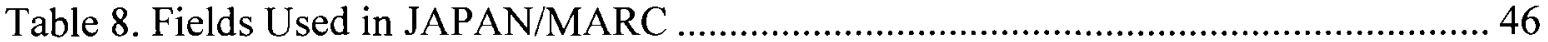

Table 9. Search Results: OCLC WorldCat v.s. LC Catalog ............................................. 59

Table 10. OCLC WorldCat Search Results of Shakespeare in Japanese Roman-ji............ 61

Table 11. Authority Headings Search, Library of Congress Authorities ............................ 67 


\section{List of Figures}

Figure 1. Main events in the development of CJK cataloging system in the U.S..........15

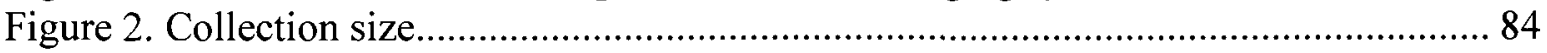

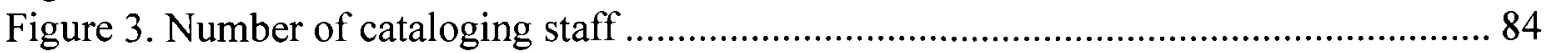

Figure 4. CJK vernacular script (input/display) in OPAC ………….............................. 85

Figure 5. Participation of CJK NACO …………......................................................... 85

Figure 6. Years in CJK NACO participation .................................................................. 86

Figure 7. Potential member (within two years) of CJK NACO ……................................... 86

Figure 8. OCLC WorldCat as a copy-cataloging tool.................................................... 91

Figure 9. Use of national level bibliographic databases for searching titles....................... 91

Figure 10. Locations of outsourced cataloging vendors for CJK monographs.................... 91

Figure 11. Shelf-ready service from outsourced cataloging vendors................................. 92

Figure 12. Benefits of outsourced cataloging...................................................................... 92

Figure 13. Number of backlogged CJK materials............................................................ 94

Figure 14. Management of backlogged CJK materials ........................................................ 94

Figure 15. Update and maintenance of bibliographic records ....................................... 100

Figure 16. Update and maintenance of authority records ............................................... 100

Figure 17. Lists of top 22 language proficiencies for librarians ...................................... 102

Figure 18. Language proficiency level (reading/writing/speaking) in Chinese .................. 103

Figure 19. Language proficiency level (reading/writing/speaking) in Japanese................. 104

Figure 20. Language proficiency level (reading/writing/speaking) in Korean ................... 104

Figure 21. Lists of cataloging activities for CJK library materials .................................. 105 
List of Abbreviations

AACR2: Anglo-American Cataloguing Rules, 2nd Edition

AACR2R: Anglo-American Cataloguing Rules, 2nd Revised Edition

ALA: American Library Association

ALCTS: Association for Library Collections and Technical Services

ASCII: American Standard Code for Information Interchange

BALLOT: Bibliographic Automation of Large Library Operations Using a Timesharing System

BIBCO: Bibliographic Record Cooperative Program

CONSER: Cooperative Online Serials

CEAL: Council on East Asian Libraries

CJK: Chinese, Japanese, and Korean

EACC: East Asian Character Code

EISI: Electronic Information Solutions, Inc.

ELUNA: ExLibris Users of North America

FRANAR: Functional Requirements and Numbering of Authority Records

FRBR: Functional Requirements for Bibliographic Records

ILS: Integrated Library System

ISBD: International Standard Bibliographic Description

ISO: International Organization for Standardization

JACKPHY: Japanese, Arabic, Chinese, Korean, Persian, Hebrew, and Yiddish

JIS: Japanese Industrial Standards 
LC: Library of Congress

LC/NAF: Library of Congress/Name Authority File

LCRI: Library of Congress Rule Interpretations

LCSH: Library of Congress Subject Headings

LIS: Library \& Information Science

LITA: Library Information and Information Technology Association

LSP: Linked Systems Project

MARBI: Machine-Readable Bibliographic Information

MARC: Machine Readable Cataloging

MLS: Master of Library Science

NACO: Name Authority Cooperative

NAR: Name Authority Record

NCTPG: Northern California Technical Processes Group

NDL: National Diet Library

NDLC: National Diet Library Classification

NII: National Institute of Informatics

NPAC: National Program for Acquisitions and Cataloging

OCLC: Online Computer Library Center

OPAC: Online Public Access Catalog

OPC: Orientalia Processing Committee

PCC: Program for Cooperative Cataloging

RDA: Resource Description and Access 
RLG: Research Libraries Group

RLIN: Research Libraries Information Network

SACO: Subject Authority Cooperative

SCCOM: Special Committee on Cataloging Oriental Materials

TRC: Toshokan Ryūtsū Center

UCS: Universal Character Set

UNICODE: Universal Code

UNIMARC: Universal MARC

UTF-16: Unicode Transformation Format-16

UTF-8: Unicode Transformation Format-8

VIAF: Virtual International Authority File

WINE: Waseda Information Network 


\begin{abstract}
A Note to Reader
This study contains some Japanese names (terms) written both in Romanization and original Japanese scripts. Those Japanese names (terms) including the names of institutions (e.g., Kinokuniya), the names of special vocabularies (e.g., 小原 Ohara), and the suffixes attached to Japanese nouns (e.g., 式 shiki, 型 kata), are italicized.
\end{abstract}




\section{Introduction}

The advancement of new information technology during the past decades has gradually increased and changed the use of various foreign language materials including monographs, serials, and audiovisual materials. The higher education communities of North American university libraries have provided a wide range of resources written in East Asian languages: Chinese, Japanese, and Korean, for example. As of May 2008, approximately 150 institutions, including university libraries, special libraries (research institutions), public libraries, and 550 individuals from all over the world, participate in the Online Computer Library Center, Chinese, Japanese, and Korean (OCLC CJK) Users Group. More than 69,000 libraries in 112 countries and territories around the world use OCLC services. According to the comments received (ALA, 2006) as of December 2006, via the Association for Library Collections and Technical Services (ALCTS) Task Force on Non-English Access, libraries in the U.S. have assumed that the language of the user was English. Although many libraries have developed a collection in a variety of foreign languages, the language of the catalog including subject access points has been English. AACR2 rule 1.0 E (Language and script of the description) prescribes that give information transcribed from the item itself in the language and script in which it appears there (AACR2, 2005, 1-8). The earliest automated library systems were limited to Roman script. Cataloging for works in non-Roman scripts therefore required Romanization of any text in non-Roman scripts. With the addition of support for nonRoman scripts to MARC, "cataloging records with non-Roman data by U.S. libraries have both transcriptions of the actual scripts and Romanized ones" (Camden, 2006, p.11). 
In the last two decades, many U.S. libraries have developed CJK enhancements to their library automation systems and transitioned from conventional card catalogs to online public access catalogs (OPAC) by using CJK vernacular scripts, although nonRoman script search options of these systems are still limited. There are still some issues of inconsistency and complexity of cataloging records for CJK materials, while the East Asian library community in North America continues to deal with more complex problems regarding the cataloging of East Asian library resources. Despite all the improvements and efforts made by CJK library catalogers, their tasks of creating more precise and accurate CJK library cataloging records are still challenging, mainly due to unfamiliarity with cataloging rules and difficulties of language skills. Therefore, this thesis study intends to examine the cataloging tasks used for CJK materials, and authority control of CJK bibliographic databases, particularly of Japanese records for monographs published after the year 1900 .

In order to avoid confusion and complication of the analysis by comparing cataloging for unlike items, using different cataloging standards and rules, this study will be limited to monographic Japanese records. The problems faced by the U.S. university libraries include the variations in cataloging standards for exchanging the bibliographic records for CJK materials, due to a lack of authority control systems at the international level, and due to language difficulties. "Authority control is the use of controlled vocabulary to promote consistency in searching results" (Hanks, 2003, p.2). If authority control is not properly used, searching the right bibliographic records would be difficult for users when retrieving the information they need. Thus, this study raises some 
important issues concerning creating, maintaining, and sharing bibliographic records of CJK materials.

Since library related issues, especially for metadata and cataloging discussions, seem to be constantly updated and changed, there has not been any substantial and concise research about CJK cataloging. There are a number of articles on the discussion and evaluation of cataloging practices for English-language-materials, but few for nonRoman languages, especially that of CJK with specific details of problem and issues.

In addition, clarifying and following the cataloging guidelines and standards are crucial tasks for catalogers who maintain various authority files that are largely shared and updated by the East Asian library community. These authority files available through OCLC and LC cataloging systems are shared by the East Asian library community. Problems due to inconsistent application of cataloguing rules including AACR2 and LCRI are investigated, in order to improve vernacular script search and information retrieval among library online catalogs.

This study also reviews and discusses the current CJK cataloging activities held in U.S. university libraries, based on the survey research of selected CJK materials from cataloging librarians. This paper presents the findings and describes the problems of using multilingual competencies in cataloging performed at libraries based on a survey sent to the libraries. Outsourced cataloging and copy-cataloging is favored, due to the efficiency of cataloging workflow in terms of cost effectiveness and time efficiency, but there are the issues of quality control to be concerned. The survey findings also suggest that catalogers are often required to use languages other than English for identifying 
bibliographic elements and determining the main topic for creating subject headings for CJK language materials. The survey results also revealed that more than half of the CJK catalogers identified themselves as native or bilingual in their specialized CJK language. Chinese and Japanese specialized catalogers are neither elementary nor limited working proficiency, while Korean catalogers are a little less specialized. At the same time, there are only a few Korean-only specialized catalogers, and some Japanese copy catalogers also handle the Korean library materials. 


\section{Research Problem}

The enhancements and the improvements in the recent information retrieval of the bibliographic records for CJK materials have made it possible access to vernacular data in various library databases. However, there are some issues and problems that are still unsolved. Therefore, this study hopes to investigate and clarify these issues and problems to improve the information retrieval for Japanese monographic materials. The issues explored in this study include the following questions:

\section{Statement of Major Research Questions}

1. Are vernacular Japanese scripts present in the body of bibliographic records and authority files fully accessible and searchable?

2. What are the impacts of using parallel CJK fields in a single record? Can vernacular data (in Japanese script) be accommodated without a parallel

Romanized field? Can authority files have vernacular Japanese scripts only, instead of Romanized transliterated ones?

3. What do PCC program need to provide Japanese libraries and vendors (cataloging agencies) in order to encourage cooperative cataloging activities, especially for authority work?

4. Which guidelines of LCRI and AACR2 relating to the application of the portion of title proper are inconsistently used for creating authority records?

5. Do LC authority bibliographic records show additional data for Japanese monographs which are translated into some other Asian languages, such as Chinese or Korean? 


\section{Statement of Major Research Hypotheses}

1. Inconsistency and/or lack of cataloging rules, especially for subfields $(\$ b, \$ n$, and $\$ p$ ) in MARC records, tend to cause inaccurate search results.

2. Since many CJK names share the same Romanization (especially for personal names, corporate names, and geographic names), search results tend to be inaccurate. In order to avoid these complications, two separate records for the CJK original scripts and the Romanized ones can be created instead.

Currently, authorities need to use MARC 21's Model B for multi-script records, where non-Latin script data is entered into the same MARC tags as Romanized data. However, if vernacular Japanese scripts were entered in a single authority record, there would be more precise retrieval results.

3. The PCC members of East Asian libraries are still less than one percent of all PCC members, probably due to the lack of training documentation in East Asian languages. Thus, more opportunities for specialized training related to cataloging and authority work need to be provided for these East Asian libraries.

4. LCRI $21.30 \mathrm{~J}$ and AACR2 $1.1 \mathrm{~B} 1$ are key guidelines that need to thoroughly discussed, especially when catalogers choose the portion of title proper for monographs with long titles.

5. Besides Romanization data (of author names, titles, and publishers), all translated literature (from Japanese to Chinese, for example) should include some additional data for characters used commonly in each Asian language. 


\section{Literature Review}

The importance of the compatibility of some Japanese cataloging rules with North American ones has been intensifying and is becoming more widespread as many U.S. libraries advance from the conventional manual to automated online catalogs. However, there have not been any substantial surveys and studies of actual problems of cataloging practices done in North America. In this chapter, the author reviews literature to evaluate and examine the cataloging practices of $\mathrm{CJK}$ materials and to analyze bibliographic rules of CJK materials. The problems resulting from inconsistent ways of using the cataloging rules of CJK bibliographic records are further complicated by the problems of vernacular searching systems.

\section{History and Background to the Problem}

In the past decades, there were some primary international conferences on cataloging principles, including Paris Principles of 1961, but the issues of cataloging nonEnglish library materials had still not been thoroughly discussed until the publication of the workbook for East Asian publications in 1983. The current standard cataloging rules of Anglo-American Cataloging Rules, $2^{\text {nd }}$ edition (AACR2) which is originally based on the first edition of AACR published in 1967, helped compile a workbook illustrating the new rules with East Asian language materials for East Asian library catalogers. The second edition of AACR was published in 1978, and revised in 1988 as AACR2R. Two years later, the subcommittee on Technical Processing of the Committee on East Asian Libraries, Association for Asian Studies, started compiling the AACR2 Workbook for 
East Asian Publications. The committee took this initiative for three reasons: 1) AACR2 does not provide sufficient guidelines and examples for treating materials in East Asian languages, 2) The ISBD (International Standard Bibliographic Description) on which Part I (Description) of AACR2 is based does not have provisions and examples for unique situations in the bibliographic description of East Asian materials, 3) National, regional, and local AACR2 training institutes, sponsored by the American Library Association, the Library of Congress, and some local library associations to prepare the nation's catalogers for the implementation of the new code in 1981, did not address special problems faced by East Asian catalogers (Lee, 1983). In March 1983, the workbook was finally completed by Beatrice Ohta of the Library of Congress and Thomas Lee of the University of Wisconsin-Madison. Prior to this significant event of library cataloging in the U.S., the descriptive cataloging rules of Far Eastern materials were mentioned in $A L A$ Cataloging Rules for Authors and Title Entries and Rules for Descriptive Cataloging in the Library of Congress. More specifically, Cataloging Rules of the American Library Association and the Library of Congress: Addition and Changes, 1949-1958 contains amendments and additions to the two basic codes (Aman. 1980). This section was entitled "Far Eastern Languages; Manual of Romanization, Capitalization Punctuation, and Word Division (wakachi-gaki) for Chinese, Japanese, and Korean." Between 1949 and 1958 , cards for more than 88,000 works were reproduced and distributed: 54,278 cards for works in Chinese, 32,532 for works in Japanese, and 1,985 for Korean titles (Beal, 1973). 
The first cooperative cataloging project of the East Asian library community was the Oriental Card Reproduction Project. "The Library of Congress reproduced without editing and sold by subscription catalog cards for Chinese, Japanese, and Korean works cataloged by American libraries" (Aliprand, 1993, p.424). Between the years of 1954 and 1957, the Orientalia Processing Committee (OPC) of the Library of Congress and the American Library Association (ALA) Special Committee on Cataloging Oriental Materials (SCCOM) collaboratively worked to modify the cataloging rules for library materials written in Chinese, Japanese, and Korean. First, the committee concluded there should be no separate cataloging code for Far Eastern materials, but rather the existing American Library Association and Library of Congress rules should be modified and expanded in such a way as to make the cataloging of these materials feasible. Second, the cataloging of East Asian materials should be done in such a way that, if desired, the cards produced in accordance with them would be capable of being interfiled with cards for works in Western languages. Then, in 1957 the Association for Asian Studies announced that the newly developed cataloging rules had been adopted by all major American Library collections of East Asian publications. At the same time, "the Far Eastern Language Section was established in the Descriptive Cataloging Division of the Library of Congress, and the large-scale printing of LC cards for East Asian language monographs and serials began in the following year" (Aliprand, 1993, p.131-132). In addition, the availability of Japanese cataloging cards was facilitated in 1968 when LC established an overseas office in Tokyo and the National Program for Acquisitions and Cataloging (NPAC) was extended to Japanese materials. LC also came to collaborate 
with Japan's National Diet Library, as LC could provide cataloging copy for current Japanese works to American libraries.

The first workbook for East Asian publications was compiled and revised in March 1983 by two cataloging specialists in the U.S. libraries. This workbook includes detailed guidelines and examples for treating materials in East Asian languages, and supplements by AACR2 training institutes by addressing special problems faced by East Asian catalogers (Melzer, 2008). Six months later, with the introduction of the Research Libraries Information Network (RLIN) and with the use of the UTF-8 Unicode system, for the first time the East Asian libraries of North America were able to create machinereadable records containing vernacular Chinese, Japanese, and Korean (CJK) characters. Unicode is an international character set designed for the scripts of all languages, and now it offers better multi-script authority records. In 1977, one of the recommendations issued at the end of the International Congress on National Bibliographies organized by IFLA and UNESCO in Paris stated that "...each national bibliographic agency should maintain an authority control system for national names, personal and corporate, and uniform titles in accordance with international guidelines" (Plassard, 2001, p.105).

The capability of the RLIN system for JACKPHY (Japanese, Arabic, Chinese, Korean, Persian, Hebrew, and Yiddish) languages and scripts has been updated to a new Web-based system called RLIN21, in which data are stored in Unicode, which supports all languages and scripts (LC, 2005). RLIN, originally operated by the Research Libraries Group (RLG), is a bibliographic utility and online information retrieval system that supports cataloging and other library operations. RLIN was established in 1978 as 
an outgrowth of Bibliographic Automation of Large Library Operations using a Timesharing System (BALLOT) of Stanford University (Saffady, 1999). The creation of RLIN was a very significant event for the East Asian Library communities in the U.S., mainly because it facilitated cataloging in non-Roman scripts and it finally introduced the CJK cataloging system in 1983, proving the first bibliographic system to support cataloging and retrieval of bibliographic records in Chinese, Japanese, and Korean vernacular scripts, in which the full East Asian Character Code is used. At almost the same time, OCLC developed a similar system, Asiagraphics (Har-Nicolescu). The transition from card cataloging to machine-based automated cataloging was challenging for many CJK catalogers, although it encouraged them to review all the existing cataloging rules and formats more closely than before, according to Aliprand, a library system analyst of the former RLG. In 1987, there were more than 337,000 CJK records in RLIN, while OCLC developed a CJK cataloging workstation for adding records in the vernaculars (Falk, 1989). OCLC Asia Pacific services were established in August 1986, and started developing and managing a large shared Cataloging System supporting the input of multilingual scripts.

The East Asian Character Code (EACC) is an American standard developed by RLG and the Library of Congress in collaboration. Statistically speaking, at the end of March 1993, there were well over a million records with vernacular CJK in the RLIN database. At that time, most of these records were entered online by thirty-seven participating institutions. As of 1993, the remaining 142,391 records, mostly from OCLC, were batch loaded. Some of the most active participants include the Library of 
Congress (209,511 records), Yale University (98,488 records), Columbia University (93,728 records), the University of Michigan (72,933 records), Princeton University (64,494 records), and the University of Toronto (63,304 records) (Aliprand, 1993). As of June 2006, the number of institutions participating in RLG's program included more than 150 research libraries, archives, and museums. The other online cataloging system for CJK materials is OCLC's CJK 350 system, which was introduced in 1987, and it was used by 75 libraries including the Harvard-Yenching Library as of February 1990. CJK 350 was a multipurpose microcomputer based on IBM PC. The Chicago Public Library was the first public library in the United States to have the new equipment of a OCLC CJK workstation, when it was installed in 1987 (Hu, 2000). A year before the formal launch of OCLC's CJK system, the members of OCLC began inputting bibliographic records with Chinese, Japanese, and Korean characters using OCLC CJK software, which integrates the East Asian Character Code (EACC) (OCLC, Character Set, 5:9). "Both online cataloging systems allowed access to an overseas CJK database to facilitate copy cataloging, and extended the advantages of automation to East Asian library services" (Hu, 1990, p.71). In July 2006, RLG merged with OCLC, and the RLIN 21 cataloging system became part of OCLC's WorldCat, as they had started to directly exchange their records, bypassing LC since 1992. Of the 153 institutions that were RLG members at the signing of the agreement, $90 \%$ have elected to become RLG partners. OCLC started integrating the RLG Union Catalog, RLIN, with WorldCat, processing more than 50.4 million records and adding some 7.8 million records to WorldCat. The following statistics: OCLC Annual Report, 2007/2008 (OCLC, 2008) indicate that the bibliographic 
records of CJK, especially for Chinese and Japanese that have been distributed to OCLC, are pretty high. Of the top ten languages distributed to OCLC WorldCat, both Chinese and Japanese, along with English, German, French, Spanish, and Dutch have more than two million records.

Table 1

OCLC Number of Bibliographic Records by Language (as of June 30, 2008)

\begin{tabular}{|c|r|}
\multicolumn{1}{c|}{$\begin{array}{c}\text { Languages } \\
\text { English }\end{array}$} & \# of Records \\
\hline German & $55,192,687$ \\
\hline French & $12,311,742$ \\
\hline Spanish & $6,248,331$ \\
\hline Dutch & $3,602,529$ \\
\hline Japanese & $2,681,470$ \\
\hline Chinese & $2,540,136$ \\
\hline Russian & $2,362,795$ \\
\hline Italian & $1,781,390$ \\
\hline & $1,693,616$ \\
\hline
\end{tabular}

It was a productive period during which the Technical Processing Committee of the Council on East Asian Libraries (CEAL) evaluated the contents of the AACR2 workbook for East Asian publications after the original one was published in 1983. CEAL agreed in 1996 that a revision of the workbook was needed, as they wished not only to update the workbook to reflect changes to AACR2 and LCRIs, but also to broaden the scope to include the rules that govern specific types of materials such as maps and atlases, music and sound recordings, and motion pictures and video recording, as well as other types of electronic resources and references: This project has been undertaken by CEAL and $\mathrm{LC}$, and the committee decided that a digital version of the examples should be posted on the Web, rather than printing them in book or notebook 
form, to make them conveniently available to a wider audience (Melzer, 2008). The project started in early 1997 and finally provided users with a wide range of examples in all three of the CJK languages. Philip Melzer, a former president (2006-2008) of CEAL who served on the committee for the revision, comments that the project to add non-Latin data to authority records began in July 2008, and seventeen chapters in total have been revised so far. 


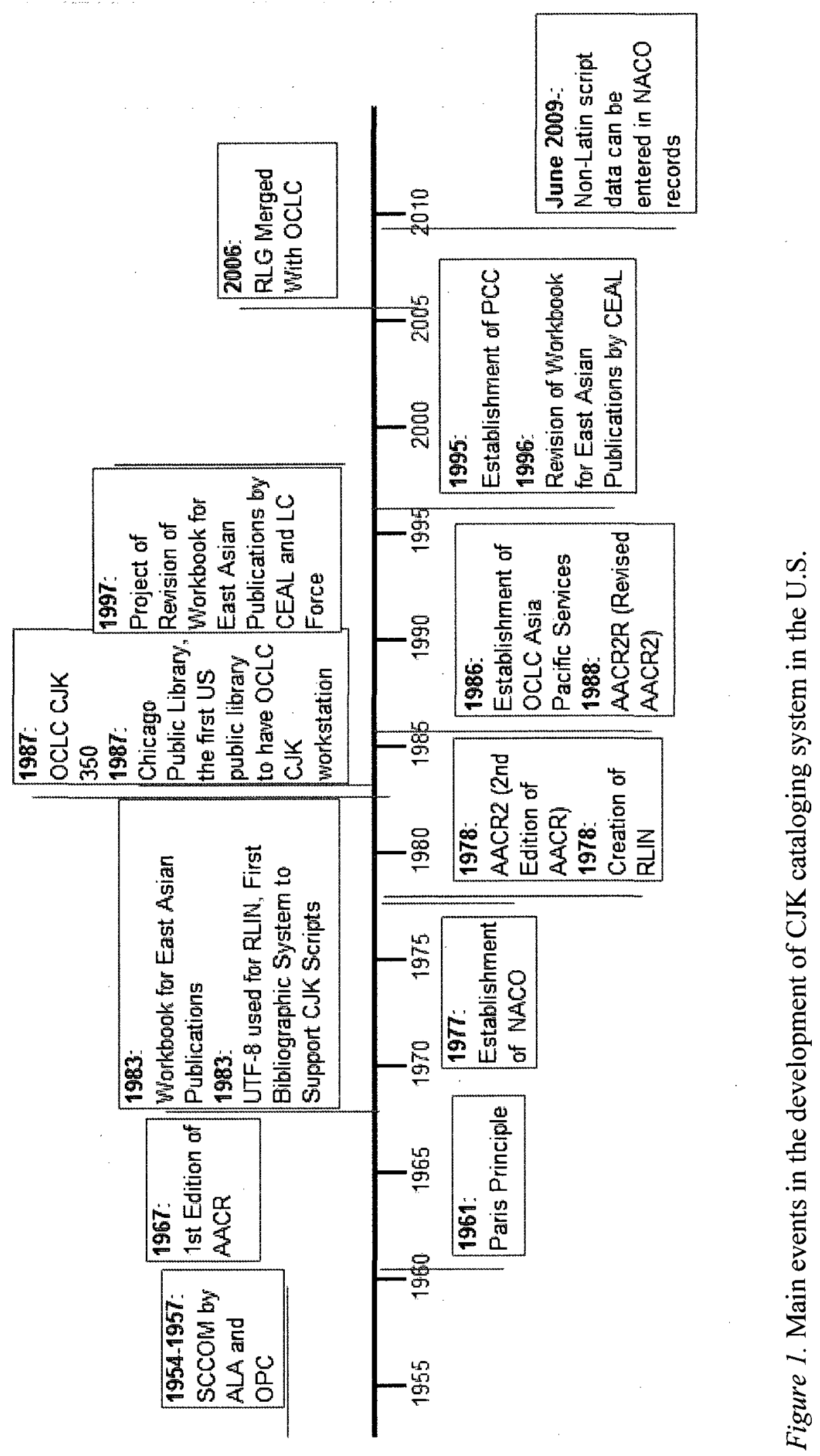




\section{Japanese Writing System and its Romanization}

Before presenting further details of the authority control of Japanese library materials, we need to have a better understanding of two basic concepts, scripts and language, which are the important sources of authority control.

In Japanese writing, some scripts are intermixed: hiragana, katakana, kanji, and Romanji (Latin script). Kanji (Chinese characters) are ideographs which convey meaning rather than particular sound. More specifically, there are five different kinds of scripts used in Japanese writing system. Kanji (ideograms), hiragana (phonograms) used mainly for particles and verb endings, katakana (phonograms) used for foreign words and onomatopoeia, Roman alphabet (Roman numeral) for proper names, measures, and abbreviations, and lastly Arabic numerals. "Kanji, as ideograms, can be pronounced in various ways in Japanese, while most Chinese characters are pronounced in a single way in a Chinese dialect" (Harai, 2007, p.55), as shown in the example below.

山 pronounced as yama and san

森 pronounced as mori and shin

女 pronounced as onna, jyo, nyo, and me

Therefore, Chinese ideographic characters, kanji have more than one way of representation of kana, which is widely known as yomi (pronunciation) in Japanese. Kana gives phonetic information of the word. There are two yomi used in Japanese kanji: kun and on. The former is for Japanese reading, and the latter Chinese reading. For example, kanji 山 can be pronounced as yama (kun) and san (on). Kana has two forms: one is hiragana, the other katakana. Kana representation may have multiple kanji 
representations, according to Miyazawa's explanation (Miyazawa, 2007). For example, $k a n j i$ 香 has kana representation か $(k a)$, but the same kanji 香 can also read as こう $(k \bar{o})$ and さょう $(k y \bar{o})$, while kana representation か $(k a)$ can be some other kanji representation, such as 夏, 課, 科, 蚊, 可, 家, 下, 歌, and much more.

For these reasons, transliteration is not ideally suitable for these ideographic Japanese characters. It might serve as a way for certain users to read records, but it would be better if they could use the original scripts in terms of accuracy. Otherwise, they lose their meaning. Original Japanese transcription in this case is very important and useful for information retrieval. The basic requirement of a user is the ability to locate and search the library catalog using her or his preferred language, and that language needs to be written in the proper script, not just Romanization. Of the three common types of Japanese Romanization systems (Hepburn, Nippon-shiki, and Kunreishiki known as ISO3602) that are used, the Hepburn Romanization system is most commonly used in English library catalogs. For the LC Romanization Tables, the modified Hepburn system is used, and it is based on Kenkyūsha's New Japanese-English Dictionary ( $3^{\text {rd }}$ and later editions).

Kana can also be used along with kanji for the bibliographic records of the U.S. library catalogs, as many records created by the Japanese institutions have both of them. As for the subfields used in the MARC 100 field, while there is no yomi (pronunciation) used for the author's name written in Japanese kana in the bibliographic record created by the U.S. university library, the bibliographic records found in the Japanese institutions including that of National Diet Library (NDL) includes yomi (Irie, 2009). The first 
example shown below has kana ("K"), roman-ji ("R"), and wakachi-gaki ("W") for the MARC fields 100, 245, 260, and 650.

Example MARC Record 1 (the Japanese university library)

$1001 . \$ \mathrm{a}$ 最相, 葉月\$d(1963-)

$24510 \$ a$ 絶対音感 $/ \$ \mathrm{c}$ 最相葉月著

260 .. \$a 東京: \$b 小学館, $\$ c 1998.3$

300 .. \$a337 p. ; $\$ \mathrm{c} 20 \mathrm{~cm}$.

504 .. \$a 参考文献: p. 323-334

534 .. \$n 第 4 回「週間ポスト」「SAPIO」21 世紀国際ノンフィクション大賞受賞

作に大幅に加筆・修正したもの

$650.7 \$ a$ 音楽

K100 1.\$a サイショウ,ハズキ\$d(1963-) (in kana

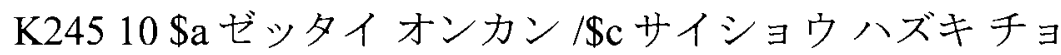

K260 .. \$a トウキョウ:\$bショウガクカン, \$c1998.3

K650.7 \$a オンガク

R100 1. \$aSaisho, Hazuki,\$d1963- （in Roman-ji (Romanization)

R245 10 \$aZettai onkan / \$cSaisho Hazuki cho

R260 .. \$aTokyo :\$bShogakukan,\$c1998.3

R650 .7 \$aOngaku

$\mathrm{W} 1001 . \$ \mathrm{a}$ 最相, 葉月 $\$ \mathrm{~d}(1963-$ ) (in Wakachi-gaki (Word division)

$\mathrm{W} 24510 \$ a$ 絶対音感 $/ \$ \mathrm{c}$ 最相葉月 著

W260 .. \$a 東京 : \$b 小学館,\$c1998.3

$\mathrm{W} 650.7 \$ a$ 音楽

Example MARC Record 2 (the U.S. university library)

1001 |6 01 |a Saishō, Hazuki, |d 1963-

$1001|601| a$ 最相葉月, $\mid d 1963-$

$24510|602| a$ Zettai onkan = |b Absolute pitch / $\mid \mathrm{c}$ Saishō Hazuki.

$24510|602| a$ 絶対音感 $=\mid b$ Absolute pitch / $\mid c$ 最相葉月.

$24631 \mid a$ Absolute pitch

$250|603|$ a Shohan.

$250|603| \mathrm{a}$ 初版.

$260|604| a$ Tōkyō : |b Shōgakkan, |c 1998.

$260|604| \mathrm{a}$ 東京: | $\mathrm{b}$ 小学館, $\mid \mathrm{c} 1998$.

$300 \mid$ a 337 p.; |c $20 \mathrm{~cm}$. 
504 a Includes bibliographical references (p. 323-334) and index.

586 |6 05 |a "Dai 4-kai ... 21-seiki kokusai non-fikushon taishō ni ... kahitsu, shyūsei."

$586|605| \mathrm{a}$ "第 4 回 ... 21 世紀国際ノンフィクション大賞に ... 加筆・修正."

$\mathbf{6 5 0} 0$ a Musical pitch.

$\mathbf{6 5 0} 0$ a Musical dictation.

6500 a Music $\mid x$ Instruction and study $\mid z$ Japan.

\section{Authority Control for CJK Cataloging System}

Authority control is the result of the process of maintaining consistency in the verbal form used to represent an access point and the further process of showing the relationships among names, works, and subjects. Authority records which contain all the forms used for a particular name (for persons, meetings, organizations, and geographic names), title, or subject, are one of the most important cataloging functions to gain access to information packages related to the name, title, or subject. Additionally, it helps provide users to have uniform access to library materials in library catalogs and to provide clear identification of authors and subject headings. As matter of fact, people in library professions started to emphasize the importance of authority files before OPAC became available a wide range of users. That was around the $1980 \mathrm{~s}$, a few years before documentation stating the importance of shared and cooperative authority records between libraries came into focus more than before. "Progress in the field of authority control brings precision, speed, economy, and greater coverage for sharing and exchange" (Buizza, 2004, p.129). It designates one of the forms as the authorized or default one to use in catalog records (Taylor, 2006). 
Authority control is a set of procedures to update the authority file and to maintain consistency in the form of the headings used in bibliographic records by verifying the headings against the authority file. Although authority records do not represent the details of library materials, they are a useful tool particularly favored by librarians, who are in technical services to organize their online library catalogs. Under authority control, various forms of the same name, subject, and title will be brought together under one authorized heading in order to improve the precision of information retrieval. It is also important to note that authority control is a very labor-intensive and time-consuming process for a library to undertake (Zhu and Seggern, 2005). "The more it is unique and general, the more authority control is efficient" (Tartaglia, 2004, p.367). This is part of the reason why cooperative cataloging such as NACO and SACO play an important role in helping libraries to have more efficient and cost beneficial ways to create and maintain their authority files.

Burger (1985) presented the role of the authority record by listing specific characteristics. The Authority record: 1) records a form of access point that is prescribed by the cataloging code, 2) ensures the collocation of records in a bibliographic file that have the same access point, 3) ensures the issuance of standardized bibliographic surrogates, 4) documents decisions taken with respect to the form of access point, 5) can record, as cross-references, variant manifestations of access points.

The authority file consists of: 1) authority records, identifying the established form of access points, 2) cross-references from variant forms to the preferred form of the access point, 3) links between earlier and later forms of headings, 4) links relating to 
broader and narrower subjects, and 5) information concerning the scope of certain items (Marais, 2004).

This is especially important for us to note when we create and search for the authority files for personal names. In order to avoid this confusion, two basic descriptions need to be discussed as follows: 1) Show the original Japanese script for the main entry for a personal name, MARC 100 field, 2) Include dates associated with a name under the subfield $d$ of the MARC 100 field. For instance, the example records below (the MARC records of LC) shows that there are two different persons with the same name ("Suzuki, Hiroshi") and written with the exact same Chinese characters (鈴木 博). In this case, the subfield $d$ of MARC 100 field and that of the 880 field indicate the date of birth, and they help differentiate these two authors.

Example Record 1

\begin{tabular}{|c|c|}
\hline 100 & 1_|6 880-01 |a Suzuki, Hiroshi, |d 1922- \\
\hline & $10 \mid 6880-02$ a Muromachi jidaigo no kenkyū / |c Suzuki Hiroshi cho. \\
\hline & | 6 880-03 |a Ōsaka-shi : |b Seibundō, |c 1988. \\
\hline & a iv, 392 p. : |b ill.; $\mid \mathrm{c} 22 \mathrm{~cm}$. \\
\hline & 0 |a Japanese language |y Middle Japanese, $1185-1600$. \\
\hline 880 & 1_ 6 100-01/\$1 |a 鈴木博, $\mid \mathrm{d} 1922-$ \\
\hline 880 & $10|6245-02 / \$ 1| \mathrm{a}$ 室町時代語の研究 / $\mid \mathrm{c}$ 鈴木博著. \\
\hline & |6 260-03/\$1 |a 大阪市: |b 清文堂, |c 1988. \\
\hline
\end{tabular}


Example Record 2

\begin{tabular}{|c|c|}
\hline 100 & 1_|6 880-01 |a Suzuki, Hiroshi, |d 1925- \\
\hline & $\begin{array}{l}10|6880-02| \mathrm{a} \text { Kindai hoteru keieiron }=\mid \mathrm{b} \text { Modern hotel administration } / \mid \mathrm{c} \text { Suzuki } \\
\text { Hiroshi. }\end{array}$ \\
\hline & |6 880-03 |a Tōkyo $\square$ : |b Shibata Shoten, |c Shōwa 39 [1964] \\
\hline & a 200 p. : |b ill.; ; $22 \mathrm{~cm}$. \\
\hline 880 & 1_|6 100-01/\$1 |a 鈴木博, |d 1925- \\
\hline 880 & $10 \mid 6$ 245-02/\$1 |a 近代ホテル経営論 = |b Modern hotel administration / $\mid c$ 鈴木博 \\
\hline & |6 260-03/\$1 |a 東京: |b 柴田書店, |c 昭和 39 [1964] \\
\hline
\end{tabular}

The authority file is an extremely important link between users and documents because of terminological barriers. Librarians therefore should educate users much better in using authority files, because they can help with identifying the material (Sauperl, 2002, p.184). Authority control is also concerned with: 1) application of AACR2 and related Library of Congress Rule Interpretations (LCRIs), 2 ) problems faced in catalogs such as split files, blind references, data-migration errors, typographical errors (some very common ones), tagging errors, indicator errors, subfield coding errors, 3) determining which errors have an impact on the ability of users to access records and which do not, 4) how to prioritize projects based on the impact that they will have on the catalog, 5) where to find answers (e.g., MARC format for authorities, Subject Cataloging Manual, $A A C R 2$, authority file), 6) automated authority control within an Online Public Access Catalog (OPAC), 7) authority control vendors and the services they offer, 8) resources that can be used to identify errors in and updates to the Catalog (Mugridge and Furniss, 2002).

The authority file is an important part in cataloging, since catalogers need to search authority records before establishing names, corporate and subject headings. 
There are several different types of authority files such as the name authority file, which includes an alphabetical list of geographic, personal, corporate, and conference names that can be found in library catalogs. The following is the fundamental structure of authority files in MARC 21 format which has been standardized by the Library of Congress. It is called Library of Congress Name Authority File (LC/NAF).

Control Fields

001: Authority Record Control Number

005: Date and Time of Latest Transaction

008: Fixed-Length Data Elements

Variable Fields

010: LC Authority Record Control Number

020: International Standard Book Number (ISBN)

035: Local System Control Number

040: Cataloging Source

053: LC Classification Number

083: Dewey Decimal Classification Number

090: Local Call Number

Headings (The $1 \mathrm{xx}$ Fields)

100: Personal Name

110: Corporate Name

111: Meeting Name

130: Uniform Title

148: Chronological Term

150: Topical Term

151: Geographic Name

155: Genre/Form Term

180: General Subdivision

181: Geographic Subdivision

182: Chronological Subdivision

185: Form Subdivision

Tracing Fields (The 4xx as See From and 5xx Fields as See Also From) 400: Personal Name 410: Corporate Name 411: Meeting Name 430: Uniform Title 448: Chronological Term 
450: Topical Term

451: Geographic Name

455: Genre/Form Term

480: General Subdivision

481: Geographic Subdivision

482: Chronological Subdivision

485: Form Subdivision

500: Personal Name

510: Corporate Name

511: Meeting Name

530: Uniform Title

548: Chronological Term

550: Topical Term

551: Geographic Name

555: Genre/Form Term

580: General Subdivision

581: Geographic Subdivision

582: Chronological Subdivision

585: Form Subdivision

Notes (The 667-68x Fields)

667: Nonpublic General Note

670: Source Data Found

675: Source Data Not Found

678: Biographical or Historical Data

680: Public General Note

681: Subject Example Tracing Noțe

682: Deleted Heading Information

688: Application History Note

Location and Alternate Graphics (The 8xx Fields)

856: Electronic Location and Access

880: Alternate Graphic Representation 
Example Authority Record 1

\begin{tabular}{|c|c|}
\hline LC Control Number: & : 81033861 \\
\hline HEADING: & Ōe, Kenzaburō, 1935- \\
\hline 000 & $01008 \mathrm{cz}$ a2200289n 450 \\
\hline 001 & 1918143 \\
\hline 005 & 20081010052808.0 \\
\hline 008 & $811022 n \mid$ acannaabn $\mid \mathrm{b}$ aaa \\
\hline 010 & a n 81033861 \\
\hline 035 & a $($ OCoLC)oca00579541 \\
\hline & $\begin{array}{l}\mid \mathrm{a} \text { DLC } \mid \mathrm{b} \text { eng } \mid \mathrm{c} \text { DLC } \mid \mathrm{d} \text { DLC } \mid \mathrm{d} \text { DLC-R } \mid \mathrm{d} \text { DLC } \mid \mathrm{d} \text { OCoLC } \mid \mathrm{d} \\
\text { DLC } \mid \mathrm{d} \text { OCoLC }\end{array}$ \\
\hline 053 & 0 a PL858.E14 \\
\hline 100 & $1_{-}$a Oe, Kenzaburo, |d 1935- \\
\hline 400 & 1_|a Oe, Kendzaburo, |d 1935- \\
\hline 400 & 1_ a Dajiang, Jianyilang, |d 1935- \\
\hline 400 & | اوي، كينز ابورو |a | \\
\hline 400 & 1_la 大江健三朗, |d 1935- \\
\hline 400 & 1__a 大江健三郎, |d 1935- \\
\hline 400 & 1_la 大江健三, |d 1935- \\
\hline 400 & 1_ $\mid \mathrm{a}$ 大江建三郎, |d 1935- \\
\hline 667 & a Machine-derived non-Latin script reference project. \\
\hline 667 & a Non-Latin script references not evaluated. \\
\hline 670 & _ a Author's Yoroppa no koe, boku jishin no koe, 1962. \\
\hline 670 & a His Futbol 1860 goda, 1983: |b t.p. (Kendzaburo Oe) \\
\hline 670 & a Lai zi bian yuan de sheng yin, 2006: |b t.p. (Dajing Jianyila \\
\hline
\end{tabular}

It is important for each field of the Name Authority Record (NAR) to have a consistent and standardized form for the name. The 670 field, for example, is important to justify the heading and the cross-references created. It also contains further important information that is necessary to identify the person, corporate body, uniform title, or information that can be used to clarify relationships between the heading and other headings in the file (LC, 2005, July). In subfield $\$ a$ of the 670 field, the title proper of 
the work is cataloged, followed by the date of publication or edition of the work.

Subfield $\$ b$ of the 670 field is necessary only if information is provided to support the identification of the $1 \mathrm{xx}$ and $4 \mathrm{xx}$. The example authority record shown directly above does not have field 670 (Source Data Found) citations with non-Latin scripts. According to the LC's new cataloging guidelines, the title citation in $670 \$ \mathrm{a}$ is Romanized. Also, in $670 \$ b$, the equals sign " =" is needed before the additional non-Latin script form (LC, 2008, July 10).

As for the question whether LC has any plan to use non-Roman data in their authority record, LC explains that the major authority record exchange partners that serve as nodes for the LC/NACO Authority File have agreed to a basic outline that will allow for the addition of non-Roman references in name authority records distributed as part of the NACO program. It was expected that the use of non-Roman data authorities would begin no earlier than April of 2008. LC currently has no plans to add non-Roman data to subject authority records for the LC Subject Headings (FAQ: Non-Roman). That means that rather than using 880 fields that parallel regular MARC fields as in bibliographic records, non-Latin script references in authorities are added MARC 21's Model B for multi-script records (LC, 2007). In fact, MARC 4XX field (400-485), "see from tracing fields," is used for LC Authorities. Personal name (400), corporate name (410), and geographic name (451) are good examples of this.

In addition, non-Latin script references in authority records are found in $4 \mathrm{XX}$ fields (400-485), not parallel 880 fields, although adding non-Latin script data to authority records is still optional for NACO participant when they create a new authority 
record with a Romanized heading. Entering non-Latin scripts is currently limited to Arabic, Chinese, Cyrillic, Greek, Hebrew, Japanese, and Korean (Schiff, 2009, p.2).

For chapter 23 (Geographic Names) of the revised version of AACR2 workbook for East Asian publications explains in more detail how headings need to be established in the name or subject authority file. More specifically, it includes some examples showing that the problematic headings are divided into two groups: 1) headings always established according to descriptive cataloging conventions with authority records that always reside in the name authority file, and 2) headings always established according to subject cataloging conventions with authority records that reside in the subject authority file if used only as subject headings.

\section{PCC and East Asian Communities}

With the growth of the worldwide sharing and use of CJK bibliographic and authority records, there are many U.S. and overseas libraries and research institutions participating in the Program for Cooperative Cataloging (PCC), in order for them to share and keep a name authority database and controlled vocabulary with other library catalogs.

PCC, established in 1995, is an international cooperative work aimed at expanding access to library materials by providing useful and cost-effective cataloging. Today, PCC has four components to its program: Name Authority Cooperative (NACO), Subject Authority Cooperative (SACO), Bibliographic Record Cooperative (BIBCO), and Cooperative Online Serials (CONSER). NACO's goal was to facilitate the transformation of the LC authority file into a nationwide authority file to reduce 
duplication nationally (Marais, 2004, p.93). "NACO was established in 1977 as a result of an agreement between the Library of Congress (LC) and the U.S. Government Printing Office (GPO) to use and maintain a common name authority file, LCNAF (Library of Congress Name Authority File)" (Borbinha, Kaiser, and Ottosson, 2003, p.28).

"Before OCLC became a NACO member in 1988, OCLC users who found name authority records requiring changes had the choice of notifying LC or of submitting a proposal for changes to OCLC, who would then resubmit the proposals to LC for consideration" (Riemer \& Morgenroth, 1993, p.138). After membership, LC no longer had to field OCLC requests to update records, as OCLC could do this work itself; and OCLC users have a way to access the files that need to be modified.

The statistics of the LC Acquisitions and Bibliographic Access Directorate, PCC's CJK NACO Project for the fiscal year of 2008 (between October 1, 2007 and September 30,2008 ), show that a total of 1,205 new names have been created by PCC partners such as Fresno County Library and University of California, Berkeley, East Asian Library, and ten other U.S. libraries. At the same time, 150 names in total have been changed by these partners. However, these numbers are still less than one percent of all PCC members, and there's no participant from Asia in the list provided. Hong Kong University of Science and Technology joined the CONSER program in 2001, is an only one institution from East Asia contribute both name and series authority record independently ( $\mathrm{Wu}, 2006)$.

As the sample of PCC records in Ellett's study indicates, "among types of PCC participating libraries, English was the most prevalent language code used in the records, 
accounting for 1,932 (87.9\%) of the PCC record sample. At the same time, the percentages of PCC records for non-English resources were larger for public libraries (27.9\%) and special libraries (26.5\%) than for academic libraries (5.2\%)" (Ellett, 2005, p.116-117). As for Japanese university libraries, neither Waseda University nor the TRC Service is a participant in the NACO program, unlike some other academic institutions in Asia. However, National Diet Library of Japan has participated in promoting the international sharing and collaborative use of authority records (LEAF, 2003). Also, there is no cooperative cataloging program established among Japanese libraries so far, and it is necessary that a name authority file produced by the National Diet Library (NDL) should be rapidly distributed in Japan (Ushizaki, 1991). Joining the cooperative cataloging program at the international level is beneficial, especially because maintaining and creating the existing authority records for Japanese names by those who have longterm experience with the language and culture seems to be more accurate and updated. The authority files need to be created not only for librarians, but also end users, just as LC's Authorities (MARC Kenkyū-kai, 1990, p.10). "The shared authority control system needs to be promoted by NDL first, and then merged with the other two major Japanese cataloging systems managed by NII and TRC" (Sakamoto, 2004, p.2). As of FY2002, the NACO members outside of the U.S. contributed 14.1 percent of NACO's total contribution. "International NACO members have also been responsible for a relatively high percentage of updates to established headings" (Byrum, 2004, p.242).

Few Japanese libraries use MARC 21 and LCSH, because they contain foreign terms that are unfamiliar to most Japanese librarians. For these reasons, more outsourced 
cataloging institutions from Japan should be encouraged to participate in Library of Congress PCC programs for SACO and NACO, as their bibliographic records have been lately upgraded more with Japanese fields replaced by standardized LCRI and AACR2 descriptive rules. There are several barriers that might make it harder for many East Asian libraries outside of the U.S. to participate in the NACO program. First, certainly, the cost of creating and maintaining authority files is more than that of bibliographic records. Second, the cataloging training guidelines and manuals for PCC participation are not yet written in any East Asian languages. For example, a cataloging training manual written in Japanese could be a useful resource for those Japanese vendors. More importantly, in order to provide these guidelines for authority control, library professionals in the U.S. libraries are expected to be highly trained, although little has been written about the teaching of authority control in programs of library and information science. Taylor's study (Taylor, 2004) asks what would make authority control easier to learn, and ten respondents stated that it should be taught in library school. Another ten respondents also talked about library school classes by indicating that it would be easier to learn if it were studied in a systematic way. At the same time, "thirtytwo respondents indicated that the responsibility of the library school lies in teaching the fundamental theory and concepts of authority control, while six respondents indicated that some hands-on practice should be included" (Taylor, 2004, p.45).

Morimoto's cataloging exercises (Morimoto, 2002) related to Japanese monographs is a good format that can be useful for catalogers to review some important 
elements of OCLC CJK MARC21 format and AACR2 and LCRI, although the exercise itself is explained in English.

One researcher from the East Asian Library of U.C. Berkeley (Kuo, 2007) points out that their outsourced cataloging service provider, Kinokuniya Company (a bookstore chain) in Japan, expressed interest in performing authority work if training was made possible and available, since all the authority work is currently required to be performed by the library staff.

Kinokuniya has been a marketing agent of OCLC in Japan since 1986. Also, this Japanese vendor has supplied the LC with 250 titles along with original core level cataloging records after the agreement of the Kinokuniya Cataloging Pilot, 2006 with LC was made in May 2006. The primary motivation for this project came from the concern that a majority of the staff who process Japanese material might be eligible to retire, leaving them without sufficient staff to process incoming Japanese material. Although Kinokuniya did not perform authority work, it provided access points governed by exiting name, series, and subject authority records (Melzer, 2007). Some possible reasons for this would be that there's no component program of the PCC to represent the East Asian library community and there's no strong encouragement of the CJK community's participation.

CJK NACO. NACO participants can contribute new name authority records and also make changes to existing authority records. For normalization and standardization of authority records of the CJK languages, institutions participating in NACO, as the part of an international program out of the Library of Congress's PCC, follow a set of LC 
rules and guidelines to ensure the standard integrity of shared authority files. Non-Latin references have been added to Library of Congress/Name Authority File (LC/NAF) since July 2008. While the Romanized form continues to be the authorized heading (1XX field), NACO contributors are allowed to add references in non-Latin scripts following MARC 21's Model B for multi-script records.

The CJK NACO Project states that it offers an opportunity to institutions with East Asian materials to participate collectively, ultimately providing better standardized access to these collections (LC, 2008, July). Although anyone who catalogs CJK can apply to join the project, it is important to have an institution's support and commitment to it. In order to participate, a group of libraries and catalogers contribute their authority records to the LC-NACO authority file. This is called a funnel project. These participants usually work in the same subject area, as shown in the statistics (LC, 2008) below: LC Acquisitions and Bibliographic Access Directorate Program for Cooperative Cataloging Statistics for Multiple Library NACO Project during Mid-Year Compilation fiscal year 2008 and 2009 (LC, 2009). Of these, the CJK NACO Project has more active participation from various U.S. institutions. All the participants in this project can receive training, and a review can be done after the completion of the training. As of January 2008, there are twenty-six institutions participating in the CJK Project (LC, 2008, November), with a total of forty-three trained CJK NACO catalogers. Eight CJK NACO reviewers were identified and are currently reviewing the NACO contributors submitted by the trained libraries. The reviewers are professional catalogers from the following institutions: National Library of Medicine, Yale University, University of 
Illinois at Urbana-Champaign, Cornell University, Library of Congress (x 2), Smithsonian Institution, and University of Pittsburgh. The first PCC CJK NACO training session was held at the University of California, Berkeley campus. Training was provided to twelve catalogers from the East Asian Library Staff, as well as staff from the Institute of Transpersonal Psychology ITP Library, Getty Institution and University of Hawaii. For the training and education issues for authority control, a survey by Mugridge and Furniss stated that most librarians learn about authority work and authority control on the job rather than in library school, and some respondents commented that there is no way to learn without hands-on experience within a particular catalog and cataloging environment (Mugridge and Furniss, 2002). A separate PCC CJK NACO training session was held in June 2007 at the Library of Congress during the ALA annual convention in Washington D.C. Nineteen librarians from fourteen East Asian libraries and collections attended the training sessions (Minutes, 2008). The guidelines (LC, 2008, January) for the CJK NACO review process and independence state that each cataloger is recommended to start creating headings after the training and proceed to the review process, which lasts approximately three to six months on average. However, the length of the review process depends on the individual libraries. Some of the East Asian libraries with relatively smaller collections may take a little longer to work towards independence. A minimum number of eighty records of acceptable quality for personal names and forty for other types of names is required for a cataloger to be eligible for independence for a particular heading type. 
There are three important elements that reviewers need to consider during the review process. First, the cataloger who applies for the review is expected to contribute a broad range of authority records demonstrating an understanding of a variety of cataloging rules. Second, the headings submitted for review have to be more than one type, including personal names, cooperative or conference names, geographical names, and uniformed titles. Furthermore, content designation such as MARC tagging and coding that affects access is counted as a major error, besides errors in typos, spacing, capitalization, or punctuation. The number of unacceptable records needs to be no more than a 10 percent error rate in order to qualify as an independent NACO contributor. "The basic principle of NACO is that all authority contributions are to be formulated according to the rules and formats described in the following publications: the AngloAmerican Cataloging Rules second revised edition (AACR2), the MARC 21 Authority Format, and the Library of Congress Rule Interpretations (LCRIs)" (Matsui, 2001, p.6). 
Table 2

NACO Funnel Projects (10/1/2008-3/31/2009)

\begin{tabular}{|c|c|c|c|c|}
\hline \multicolumn{5}{|c|}{ Multiple NACO Funnel Projects (FY2009: 10/1/2008-3/31/2009) } \\
\hline Name of NACO Project & $\begin{array}{l}\text { New } \\
\text { Names }\end{array}$ & $\begin{array}{l}\text { New } \\
\text { Series }\end{array}$ & $\begin{array}{l}\text { Changed } \\
\text { Names }\end{array}$ & $\begin{array}{l}\text { Changed } \\
\text { Series }\end{array}$ \\
\hline Alaska Project & 6 & 2 & 16 & 2 \\
\hline Arabic Project & 469 & 1 & 179 & 1 \\
\hline Art NACO & 947 & 10 & 338 & 10 \\
\hline ATLA & 379 & 0 & 50 & 0 \\
\hline CALICO South Africa Project & 77 & 0 & 2 & 0 \\
\hline Canada Project & 34 & 0 & 7 & 0 \\
\hline Caribbean Project & 11 & 0 & 1 & 0 \\
\hline CJK NACO Project & 419 & 5 & 149 & 5 \\
\hline Connecticut Project & 198 & 0 & 21 & 0 \\
\hline Detroit Area Lib Network & 273 & 0 & 10 & 0 \\
\hline Dance Heritage Project & 0 & 0 & 0 & 0 \\
\hline GAELIC South Africa Project & 4318 & 0 & 295 & 0 \\
\hline Hagley Winterthur Project & 32 & 0 & 30 & 0 \\
\hline Hebraica Project & 376 & 2 & 101 & 2 \\
\hline Idaho Project & 132 & 0 & 54 & 0 \\
\hline Keystone Library Network & 9 & 0 & 1 & 0 \\
\hline Law Project /OCLC & 219 & 1 & 15 & 1 \\
\hline Medical Project & 137 & 0 & 11 & 0 \\
\hline Michigan Project & 2909 & 0 & 333 & 0 \\
\hline Minnesota Project & 490 & 2 & 159 & 2 \\
\hline Mississippi Project & 99 & 0 & 4 & 0 \\
\hline Montana Project & 21 & 0 & 0 & 0 \\
\hline Mountain West Project & 143 & 0 & 7 & 0 \\
\hline NACO-Mexico Project & 996 & 0 & 55 & 0 \\
\hline NACO Music & 8460 & 22 & 2603 & 22 \\
\hline New Jersey Project & 76 & 0 & 2 & 0 \\
\hline North Dakota Project & 151 & 0 & 7 & 0 \\
\hline Ohio NACO Cooperative Project & 0 & 0 & 0 & 0 \\
\hline OLAC & 2865 & 0 & 655 & 0 \\
\hline South Dakota Project & 59 & 0 & 2 & 0 \\
\hline Tennessee Project & 109 & 3 & 140 & 3 \\
\hline Texas Project & 102 & 0 & 1 & 0 \\
\hline Vermont Project & 3 & 0 & 5 & 0 \\
\hline Virginia Project & 531 & 0 & 56 & 0 \\
\hline
\end{tabular}


Table 3

CJK NACO Project (10/1/2007-3/31/2008)

\begin{tabular}{|l|r|r|r|r|}
\hline \multicolumn{5}{|c|}{ CJK NACO PROJECT (FY2008: $10 / 1 / 2007-3 / 31 / 2008)$} \\
\hline \multicolumn{1}{|c|}{ Name of Institution } & $\begin{array}{c}\text { New } \\
\text { Names }\end{array}$ & $\begin{array}{l}\text { Changed } \\
\text { Names }\end{array}$ & $\begin{array}{c}\text { New } \\
\text { Series }\end{array}$ & \multicolumn{1}{c|}{$\begin{array}{c}\text { Changed } \\
\text { Series }\end{array}$} \\
\hline California Academy of Sciences & 2 & 1 & 0 & 0 \\
\hline Fresno County Public Library & 345 & 19 & 33 & 0 \\
\hline $\begin{array}{l}\text { George Washington University Global } \\
\text { Resources }\end{array}$ & 41 & 0 & 0 & 0 \\
\hline Institute of Transpersonal Psychology & 3 & 0 & 0 & 0 \\
\hline Ohio State University, CJK Cataloging & 0 & 0 & 0 & 0 \\
\hline Stanford University East Asian Library & 51 & 3 & 0 & 0 \\
\hline $\begin{array}{l}\text { University of California, Berkeley, East } \\
\text { Asian Library }\end{array}$ & 75 & 3 & 0 & 0 \\
\hline $\begin{array}{l}\text { University of California, East Asian } \\
\text { Library }\end{array}$ & 16 & 0 & 0 & 1 \\
\hline University of Illinois, Asian Library & 1 & 0 & 0 & 0 \\
\hline $\begin{array}{l}\text { University of Southern California, East } \\
\text { Asian Library }\end{array}$ & 9 & 6 & 0 & 0 \\
\hline $\begin{array}{l}\text { University of Iowa, CJK Cataloging } \\
\text { Desk }\end{array}$ & 32 & 3 & 0 & 0 \\
\hline
\end{tabular}


Table 4

CJK NACO Project (10/1/2007-9/30/2008)

\begin{tabular}{|c|c|c|c|c|}
\hline \multicolumn{5}{|c|}{ CJK NACO PROJECT (FY2008: 10/1/2007-9/30/2008) } \\
\hline Name of Institution & $\begin{array}{l}\text { New } \\
\text { Names }\end{array}$ & $\begin{array}{l}\text { Changed } \\
\text { Names }\end{array}$ & $\begin{array}{c}\text { New } \\
\text { Series }\end{array}$ & $\begin{array}{c}\text { Changed } \\
\text { Series }\end{array}$ \\
\hline California Academy of Sciences & 8 & 6 & 0 & 0 \\
\hline Fresno County Public Library & 660 & 42 & 42 & 0 \\
\hline $\begin{array}{l}\text { George Washington University } \\
\text { Global Resources }\end{array}$ & 54 & 1 & 0 & 0 \\
\hline $\begin{array}{l}\text { Institute of Transpersonal } \\
\text { Psychology }\end{array}$ & 4 & 1 & 0 & 0 \\
\hline $\begin{array}{l}\text { Ohio State University, CJK } \\
\text { Cataloging }\end{array}$ & 13 & 3 & 0 & 0 \\
\hline $\begin{array}{l}\text { San Diego State University, CJK } \\
\text { Cataloging }\end{array}$ & 3 & 15 & 0 & 0 \\
\hline $\begin{array}{l}\text { Stanford University East Asian } \\
\text { Library }\end{array}$ & 55 & 4 & 0 & 0 \\
\hline $\begin{array}{l}\text { University of California, Berkeley, } \\
\text { East Asian Library }\end{array}$ & 224 & 37 & 0 & 0 \\
\hline $\begin{array}{l}\text { University of California, East Asian } \\
\text { Library }\end{array}$ & 40 & 0 & 1 & 2 \\
\hline University of Illionis, Asian Library & 1 & 0 & 0 & 0 \\
\hline $\begin{array}{l}\text { University of Southern California, } \\
\text { East Asian Library }\end{array}$ & 93 & 27 & 5 & 1 \\
\hline $\begin{array}{l}\text { University of Iowa, CJK Cataloging } \\
\text { Desk }\end{array}$ & 50 & 14 & 0 & 0 \\
\hline
\end{tabular}

Table 5

CJK NACO Participants

\begin{tabular}{|c|c|}
\hline \multicolumn{2}{|l|}{ CJK NACO Project Participants } \\
\hline Name of Institution & MARC code \\
\hline Brigham University & UPB \\
\hline California Academy Science Libraries, CJK Cataloging Desk & CaSfCAS \\
\hline Cornell University & NIC \\
\hline Fresno County Library & CFCPL \\
\hline George Washington University, Global Resources Center & DcWaGWGG \\
\hline Georgetown University & DGU \\
\hline Getty Research Institute & CMalG \\
\hline
\end{tabular}




\begin{tabular}{|l|l|}
\hline Institute of Transpersonal Psychology & CaPalITP \\
\hline McGill University & CaQMM \\
\hline Ohio State University, CJK Cataloging & OhCoUCJK \\
\hline Queens Borough Public Library & NJQ \\
\hline Rutgers University & NjR \\
\hline San Diego State University, CJK Cataloging Desk & CaSdUCJ \\
\hline Stanford University, East Asian Library & CaStEAL \\
\hline University of Alberta Libraries & CaAEU \\
\hline $\begin{array}{l}\text { University of California, Berkeley, C.V. Starr East Asian } \\
\text { Library }\end{array}$ & CU-EAST \\
\hline University of California, Los Angeles, East Asian Library & CaLaUCEA \\
\hline University of California, San Diego & CU-S \\
\hline University of Florida & FU \\
\hline University of Georgia & GU \\
\hline University of Hawaii & HU \\
\hline University of Illionis, Urbana Champaign, Asian Library & IIUrUAL \\
\hline University of Iowa, CJK Cataloging Desk & lalaUCJK \\
\hline University of Pittsburgh, East Asian Library & PPiU \\
\hline University of Southern California, East Asian Library & CaLaUEA \\
\hline University of Washington, East Asian Law & WaU-L \\
\hline University of the West Library & CaRomUWL \\
\hline Vanderbilt University & TNJ \\
\hline
\end{tabular}

\section{MARC Formats in Japan}

There are three different types of MARC formats used in libraries and research institutions in Japan: TRC/MARC (created by Toshokan Ryūtsū Center), WINE MARC (by Waseda University Library), NC/MARC (created by National Institute of Informatics) so-called NACSIS-CAT, and JAPAN/MARC (created by National Diet Library of Japan). Below is a brief summary of each MARC format.

TRC MARC. TRC MARC is based on enhanced JAPAN/MARC format, provided by Toshokan Ryūtsū Center (TRC), a cataloging vendor for RLG (now for OCLC). This MARC format is mainly used by public libraries in Japan. 
Table 6

Fields Used in TRC/MARC

\begin{tabular}{|l|l|}
\hline \multicolumn{1}{|c|}{ Field } & \multicolumn{1}{|c|}{ Description } \\
\hline 000 & Title code \\
\hline 010 & ISBN \\
\hline 011 & ISSN \\
\hline 020 & JP MARC Number \\
\hline 080 & TRC MARC Number \\
\hline 251 & Title Statement \\
\hline 265 & Edition Statement \\
\hline 270 & Publication and Distribution \\
\hline 275 & Physical Description \\
\hline 291 & Series Statement \\
\hline 360 & Price \\
\hline 551 & Kana Representation of the Title \\
\hline 561 & Kana Representation of Varying Form of Title \\
\hline 658 & Topical and Index Term \\
\hline 770 & Kana Representation of Publisher \\
\hline
\end{tabular}

Example TRC MARC Record 1 (Shōji, 2002, p.9)

251 \$A百回忌馬琴展覧会陳列目録\$F早稲田大学図書館編

270 \$A 東京\$B早稲田大学図書館\$D1947

275 \$A32p\$B $18 \mathrm{~cm}$

$350 \$ A$ 昭和 22 年 11 月 15 日 -20 日早稲田大学図書館に於て開催腾写版

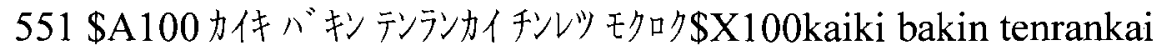
tinretu mokuroku\$B251

$677 \$ A 913.56$

751 \$Aワセダダ价゙クショカンXWaseda daigaku tosyokan\$B早稲田大学図書館 770 \$A哆ダダ仍゙クトショカ

Example TRC MARC Record 2 (Asakura, 2004, p.161)

$\begin{array}{ll}\text { 010A0001 } & 4-540-01205-3 \\ \text { 080A0001 } & 02002117 \\ \text { 080G0001 } & 30925239 \\ \text { 080S0001 } & 1258 \\ \text { 251A0001 } & \text { 花茾園芸大百科 } \\ \text { 251D0001 } & 5\end{array}$




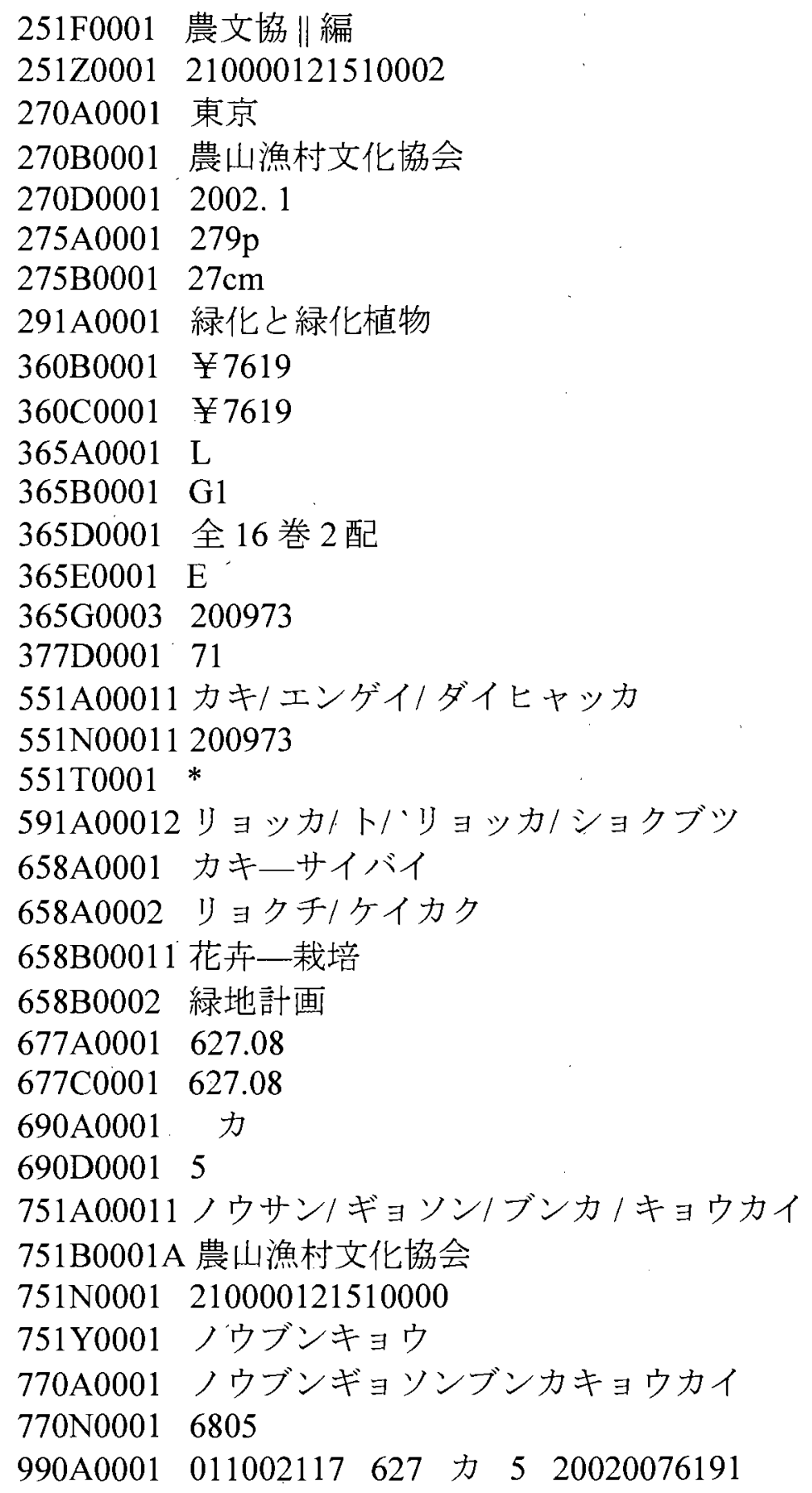

WINE MARC. Waseda Information Network (WINE) MARC records were originally converted from JAPAN/MARC format into the MARC21 format with the help of Kinokuniya Company and OCLC. WINE MARC records contain the subject headings 
based on National Diet Library List of Subject Heading (NDLLSH) in the original JAPAN/MARC format (Kotaka, 2001). As in the example records below, the details in each field $245,260,440$, and 700 have three layers of information: the original title (combination of kanji and hiragana), kana (katakana), and Roman-ji. This is one of the most unique features that WINE MARC has, and it has become compatible with MARC21 format.

Example WINE Record 1

245 |811|a あいまいな日本の私/ $/ \mathrm{c}$ 大江健三郎著 (Original title in hiragana + kanji) 245 |812|a アイマイナ ニホンノ ワタクシ $\rightarrow$ Kana (in katakana)

245 |813|aaimaina nihon no watakushi $\rightarrow$ Roman-ji (Romanization)

$260|811| \mathrm{a}$ 東京 : |b 岩波書店, $\mid \mathrm{c} 1995.1$

$260|812| \mathrm{a}$ トウキョウ:|bイワナミショテン

260 |813|atokyo:|biwanamishoten

$300 \quad 232 \mathrm{p} ; \mathrm{c} 18 \mathrm{~cm}$

$440 \quad$ |811|a 岩波新書; $\mid \mathrm{v}$ 新赤版 375

440 |812|a イワナミシンショ;|v シンアカバン(375)

440 |813|aiwanami shinsho;|vshin'akaban(375)

700 |811|a 大江 健三郎, |d1935- 4001

$700 \quad|812| \mathrm{a}$ オオエ, ケンザブロウ,|d1935-|4001

700 |813|aoe, kenzaburo,|d1935-|4001 
Example WINE Record 2

$245|811| \mathrm{a}$ マルカム・カウリー：

|b アメリカ文学を育てた文芸評論家・若き日の肖像 |

lc ジェームズ・M・ケンフ著; ケンフ智子 訳

$245|812| \mathrm{a}$ マルカム カウリー:|b アメリカブンガクオソダテタ

ブンゲイヒョウロンカワカキヒノショウゾウ

245 813 amarukamu kauri :|bamerika bungaku o sodateta bungei

hyoronka wakaki hi no shozo

$260|811| \mathrm{a}$ 東京 : $\mid \mathrm{b}$ サイマル出版会, $\mid \mathrm{c} 1988.9$

$260|812| \mathrm{a}$ トウキョウ:|b サイマル シュッパンカイ

$260 \mid 813$ atokyo : bsaimaru shuppankai

$300 \quad 237 \mathrm{p} ; \mathrm{c} 19 \mathrm{~cm}$

500 The early career of Malcolm Cowley. の翻訳

5050 文献:p233 237

$650|811|$ aCowley, Malcolm $\mid 2$ jlabsh

700 Kempf, James M.|4001

NC MARC (NACSIS-CAT). NACSIS-CAT is the national union online shared catalog databases in Japan. MARC format designed for using NACSIS-CAT records.

The format of the Bibliographic File (Tosho shoshi record) as shown below, is referenced from the introductory cataloging manual (Mokuroku System Riyō Manual, Nyūmon-hen) published by NII (Gakujutsu Jōhō Center, 1999). As of September 2008, the total number of bibliographic records for monographs created is $8,439,193$. The number of authority records for author names is $1,481,445$ (Saitō, 2008). NACSIS-CAT provides both bibliographic and authority data in non-MARC format, raw data only. NII is developing a number of international projects and cooperative efforts to improve access to information processed by overseas universities and research institutes. Currently, 31 universities and research institutes in Europe and Asia participate in NII's Cataloging Systems project and provide access to the NACSIS-CAT services (Hu, Tam, \& Lo, 
2004). Also, currently approximately one thousand libraries in Japan participate in NII's

NACSIS-CAT cataloging system (Shin Irie, personal communication, October 23, 2009).

Table 7

Fields Used in NACSIS-CAT Catalog

\begin{tabular}{|c|c|}
\hline Field & Description \\
\hline ID & ID \# for Bibliographic Record \\
\hline RECST & Record Status of MARC Record \\
\hline MARC & Change of Corresponding MARC Record Status \\
\hline CRTDT & Record Create Date \\
\hline CRTFA & Record Create Library ID \\
\hline RNWDT & Latest Record Renewal Date \\
\hline RNWFA & Latest Record Renewal Library ID \\
\hline GMD & General Material Designation Code \\
\hline SMD & Specific Material Designation Code \\
\hline YEAR & Year of Publication \\
\hline CNTRY & Country Code \\
\hline TTLL & Title Language Code \\
\hline TXTL & Text Language Code \\
\hline ORGL & Original Language Code \\
\hline REPRO & Reproduction Code \\
\hline VOL & Volumes \\
\hline ISBN & International Standard Book Number \\
\hline PRICE & Price/Terms of Availability \\
\hline XISBN & Extra ISBN \\
\hline ISSN & International Standard Serial Number \\
\hline NBN & National Bibliography Number \\
\hline NDLCN & National Diet Library Card Number \\
\hline LCCN & Library of Congress Card Number \\
\hline GPON & Government Printing Office Item Number \\
\hline OTHN & Other Numbers \\
\hline TR & Title and Statement of Responsibility Area \\
\hline ED & Edition Area \\
\hline PUB & Publication, Distribution, etc., Area \\
\hline PHYS & Physical Description Area \\
\hline VT & Variant Titles \\
\hline $\mathrm{CW}$ & Contents of Works \\
\hline NOTE & Note \\
\hline PTBL & Parent Bibliography Link \\
\hline AL & Author Link \\
\hline
\end{tabular}




\begin{tabular}{|l|l|}
\hline UTL & Uniform Title Link \\
\hline CLS & Classification \\
\hline SH & Subject Headings \\
\hline REM & Remainder of MARC Record \\
\hline
\end{tabular}

Example NC MARC Record 1 (Shōji, 2002, p.11)

ID : AA11459643 DBNAME : SERIAL CRTDT : 20000619 : RNWDT : 20000629

PSTAT : c

YEAR1 : 1997 CNTRY : ja FREQ : b TYPE : p TTLL : jpn TXTL : jpn

TRD：早稲田文学. [第 9 次] : the Waseda bungaku / 早稲田文学編集室 [編]

TRR： ワセダブンガク.[ダイ $9 シ ゙]$

VLYR: Vol. 22, [no.] 1 (1997.5)-

PUBP : 東京

PUBL：早稲田文学会

PUBDT : $1997-$

NOTE : 早稲田文学第 8 次の編集後記に「次号より隔月刊化し第 9 次早稲田文学 として再出発」との記事あり

AHDNG：早稲田文学会

AHDNGR : ワセダブンガクカイ 
Example Authority File from NACSIS-CAT Data (Sakai \& Kyoto, 2001, p.233)

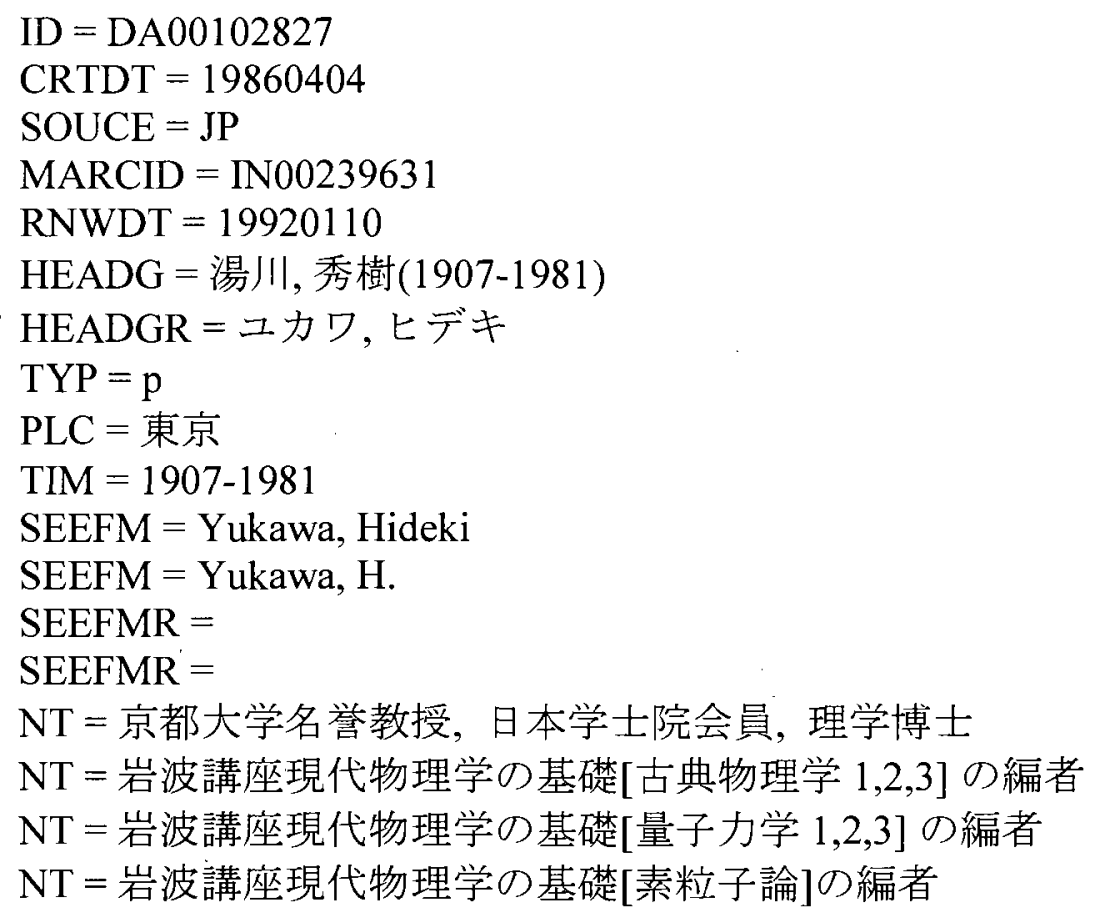

JAPAN/MARC. JAPAN/MARC files are the original cataloging developed by the National Diet Library (Wei, Harrison, and Kim, 1998). This was developed in 1981, and recorded information in Chinese characters for the first time in the world (Bunparit, 1998). JAPAN/MARC is based on the application of the UNIMARC format and data are made according to the Nippon Cataloging Rules (NCR). The following is an outline of the data elements used in JAPAN/MARC (Yokoyama, 2001). The JAPAN/MARC format generally conforms to that of UNIMARC with some modifications made in the use of 5xx, 6xx, and 7xx blocks (Kokabi, 1996). Importantly, the fields 500-599 are noted for an access point: title headings, author headings and subject headings. Also, fields 650 for personal name used as subject heading and 658 topical subject headings have fields $\$ \mathrm{a}$ for kana, $\$ \mathrm{x}$ for Romanized forms, and $\$ \mathrm{~b}$ for kanji (Kokabi, 1995). 
Table 8

Fields Used in JAPAN/MARC

\begin{tabular}{|c|c|}
\hline Field & Description \\
\hline $0 \mathrm{xx}$ & Identification Block \\
\hline 001 & Record Identifier \\
\hline 005 & Version Identifier \\
\hline $1 \mathrm{xx}$ & Coded Information Block \\
\hline $100^{*}$ & General Processing Data \\
\hline 152 & Rules \\
\hline $2 \mathrm{xx}$ & Heading Block \\
\hline \multirow[t]{7}{*}{200} & Personal Name \\
\hline & \$a: Family name or non-separated name \\
\hline & \$b: Given name \\
\hline & \$c: Part of name other than family and given names \\
\hline & \$d: Numerals relating to lineage, etc. \\
\hline & \$f: Dates, etc. \\
\hline & \$g: Other additions \\
\hline 210 & Cooperate Body Name \\
\hline 275 & Physical Description Area \\
\hline $3 \mathrm{xx}$ & Information Note Block \\
\hline 300 & Notes for Names \\
\hline 301 & Notes for Dates \\
\hline $4 \mathrm{xx}$ & See Reference \\
\hline $5 \mathrm{xx}$ & See Also Reference \\
\hline $6 \mathrm{xx}$ & Subject Added Block \\
\hline $650^{\circ}$ & Personal Name \\
\hline 658 & Topical Subject Headings \\
\hline 677 & Nippon Decimal Classification (NDC) \\
\hline 685 & National Diet Library Classification (NDLC) \\
\hline $7 \mathrm{xx}$ & Linking Heading Block used for Subject Headings \\
\hline $8 \mathrm{xx}$ & Source Information Block \\
\hline 801 & Originating Source \\
\hline 810 & Source Data Found \\
\hline 830 & General Cataloger's Note \\
\hline 831 & Notes for Kanji (Chinese Character) \\
\hline 835 & Deleted Heading Information \\
\hline
\end{tabular}

Note. The field 100, general processing data includes the following information: date entered on file, status of authority heading code, language of cataloging, transliteration code, character set, and script of cataloging. 
Example JAPAN/MARC Record (Shōji, 2002, p.5)

251 \$A 百回忌馬琴展覧会陳列目録\$F·早稲田大学図書館編

270 \$A 東京 \$B 早稲田大学図書館\$D1947

$275 \$ A 32 \mathrm{p} \$ B 18 \mathrm{~cm}$

$350 \$ A$ 昭和 22 年 11 月 15 日 - 20 日早稲田大学図書館に於て開催腾写版

551 \$A 100 カ价バキンテラランカインルリモク㕫 \$X 100kaiki bakin tenrankai tinretu mokuroku \$B 251

$677 \$$ A 913.56

751 \$ 听ダダ价゙クショカン $\$ X$ Waseda daigaku tosyokan\$B早稲田大学図書館

Example Authority File for JAPAN/MARC (Ozawa, 2001, p.199)

200 1\$6a01\$a湯川\$b秀樹

200 1\$6a01\$7dc\$aユカワ,\$bヒデキ

200 1\$6a01\$7ba\$aYukawa,\$bHideki

301 \$a1907-1981

801 0\$aJP\$bNDL\$c20001122

810 \$a物質観之世界観

810 \$a根拠:文化人名録

830 \$a京大·教授,理博,理論物理学者

830 \$aノーベル物理学賞受賞

911 \$ap\$ba

\section{OCLC as International Standards}

OCLC's partnership, the so-called "vender record contribution program" with some Japanese libraries and institutions as of 2008, includes Waseda University (OCLC symbol "LWU"), Toshokan Ryūtsū Center (OCLC symbol "TRCLS"), and Keio University Library (OCLC symbol "KEI"). Waseda University Library, for example, processes their bibliographic records for Japanese language materials to be batch-loaded directly into OCLC WorldCat. According to the OCLC Annual Report for the year 2007 and 2008, TRC is one of OCLC's major batchloads. The number of records processed was 732,484 . 
JAPAN/MARC is "a more UNIMARC-like format used for domestic publications, while MARC 21 is used for foreign publications" (Drake, 2005, p.27). As discussed in Miura and Matsui's study (Miura and Matsui, 2000) on changes in the shared construction of authority control files, the major cataloging system used primarily in university libraries of Japan is NACSIS-CAT, the online cataloging system provided and managed by National Institute of Informatics (NII), Kokuritsu Johōgaku Kenkyüjyo. NACSIS is the former name of the National Institution of Informatics (NII) and it used to be an institution of the federal government (Shimada, 2005). NII was founded in 2000, taking after the former National Center for Science Information Systems (NACSIS), which was originally established in 1986 (Niimoto, 2004). NACSIS-CAT has developed since 1984, and the number of university libraries connected online to NACSIS-CAT amounted to 1,188 and the total number of holdings had reached about 93 million (books: 88.7 million, serials: 4.3 million), as of March 2007. It provides a shared cataloging facility as well as a union catalog. These services are available free of charge. The main purpose of the system is to construct union catalogs of books and serials covering the whole country through cooperative data entry and shared cataloging from participating university libraries.

It also refers to standard bibliographical databases such as JAPAN MARC and US MARC for efficient input work, and adopts a shared cataloging system to prevent duplicate cataloging work in libraries and to achieve labor saving and quicker processing (NACSIS-CAT/ILL). At the same time, "different bibliographic formats and cataloging rules make the transition from a national format to an international format difficult" 
(Jordan, 2003, 109). The database of NACSIS-CAT is updated weekly on Sundays. There are a total of 703 universities in Japan: 87 national universities, 550 private universities, and 66 public universities. All Japanese university cataloging data systems are compatible with the NACSIS/MARC format.

However, Waseda University uses OCLC Cataloging service instead of NII. For a library system, they use INNOPAC which is not compatible with NACSIS/MARC. The information network system within the Waseda University library system OPAC is called Waseda University Scholarly Information Network System (WINE). Waseda University has added Japanese bibliographic records to WorldCat since 1995, sending Japanese records to OCLC (OCLC symbol: LWU) on a regular basis, approximately 3,000 records per month, since April 2004. 800,000 records in total have been added to OCLC as of October 2004. This number accounts for 65 percent of the WorldCat Japanese records (Niimoto, 2004). Compared to the NACSIS online union cataloging system, in terms of quality control, OCLC has stronger ability and the leadership, which helps member libraries to have less commitment of database maintenance, according to Yoshida's report on Waseda University Library's cataloging practice with OCLC service (Yoshida, 2000). However, some East Asian libraries of the U.S. agreed that adding new name authority records to the database is the shared responsibility of all users and that name authority records should indicate names of contributing libraries, while they disagree about whether adding information to the permanent authority record in the database is the responsibility of all users or only a national cataloging agency (Kim, 1984). This tendency can be observed in the activities of NACO and NACSIS-CAT. For 
the aspects of organization and participation, NACO is led by the LC as well as the bibliographic utility of OCLC (with RLIN), and there are a variety of participating institutions. On the other hand, "NACSIS has a more unified leadership and homogenous participants" (Matsui, 2005, p.11).

The other bibliographic data provided by Toshokan Ryūtsū Center (TRC) has been transferred to OCLC WorldCat. "The advantage of TRC MARC is its immediate availability even before publication" (Drake, 2005, p.27). TRC used to be a partner with RLG, but now OCLC has merged into RLG. All the records previously provided by TRC have automatically been transferred to the current records of the OCLC WorldCat system. The records (OCLC symbol: TRCLS) contain Japanese script as well as Latin transliteration of Japanese (OCLC, 2008). More cataloging agencies such as TRC and Kinokuniya, mentioned earlier in this paper, have become more active, as their records have been loaded into the cataloging systems of OCLC and LC, but there are still many East Asian Studies libraries which are not fully mounted in the cataloging practices that most North American institutions use. According to Morimoto's research, "the JAPAN/MARC records are not mounted in WorldCat, and OCLC has no immediate plan of loading those JAPAN/MARC records into each bibliographic file" (Morimoto, 2006, p.6). Hideyuki Morimoto, a Japanese cataloger of Columbia University Libraries, has lately evaluated some Japanese bibliographic records loaded from Keio University Libraries into the former RLG union catalog, and points out some issues of compatibility of cataloging practices between that of Japan and North America. His study concentrates on the comparison of these two countries' cataloging practices in terms of subject 
headings, capitalization, Romanization and original script data pair fields. His study shows how the problems resulting from each independent bibliographic rule and system are getting more complicated. For example, some records which have already been loaded into former RLG bibliographic records (RLG merged with OCLC in 2006) from Japanese university libraries follow the capitalization rules of personal names differently.

Naito's study points out that personal names (author names), as part of authority control, are problematic since author names appear in different languages, or one person appears in various countries in different forms of local Asian languages such as Chinese, Korean, and Japanese. If a Japanese author name is translated into the Chinese language, then a bibliographic record needs to be added with data for Chinese users, by including Chinese characters commonly used in China: Romanization in the standard Chinese Pinyin, Chinese characters in the Japanese original way, and original Japanese data, for example. Morimoto also mentions that, although many bibliographic records based on Japanese are loaded in North American bibliographic utility databases, some of them which are originally from Japan are not readily usable without performing extensive editing and checking in North America because there have been no systematic attempts to harmonize the Japanese cataloging standards and North American ones (Morimoto, 1999). 
Example Record for Authority (Format: JAPAN/MARC)

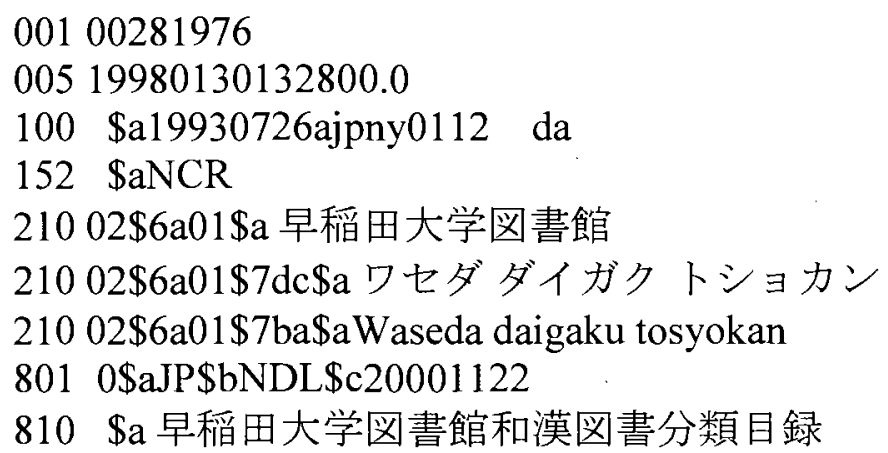

As for the name headings, there are many Japanese names, including personal names, geographical names, publisher names, that are pronounced the same way, and $\mathrm{Yu}$ points out that CJK names established in Roman form have seriously impacted the effectiveness of identifying the correct name headings in the Online Name Authority File because so many CJK names share the same Romanization. Yu's discussion includes how to improve the accessibility, uniformity, quality, and comprehensibility of the current practices of creating authority files. "The future of the online name authority file must be a multi-purpose file to serve as: 1) an index to literary authors and to authors in other applicable subject areas by providing LC classification numbers, 2) a subject analysis reference tool by providing LC Subject Headings to appropriate name authority records; and 3) a simple biographic reference tool by providing brief biographical data to appropriate name authority records" (Yu, 1999, p.7). Authority control of names and works authorized by Library of Congress, in this case, seems to be systematically controlled, but there is an issue about the management of an international authority control which could be handled by various countries with their various languages. 
Through the use of consistent forms of access points, authority control helps users to identify and locate the materials they need.

The Statement of International Cataloging Principles, the draft approved by the IFLA Meeting of Experts on an International Cataloging Code states the use of access points in relation to various languages:

When names have been expressed in several languages, preference should be given to a heading based on information found on manifestations of the expression in the original language and script; but if the original language and script is one not normally used in the catalog, the heading may be based on forms found on manifestations or in references in one of the languages and scripts best suited to the users of the catalog. Access should be provided in the original language and script whenever possible, through either the authorized heading or a reference. If transliterations are desirable, an international standard for script conversion should be followed (LC, 2005).

Since the creation of authority files needs to be handled carefully by catalogers, not by automated systems, an authority control among CJK languages involves some problems for standardization. Aliprand points out that "a number of general design issues apply to authority records in multiple languages and to scripts that affect institutions or organizations involved with authority control" (Aliprand, 2005, p.243).

Thus, the challenge faced by these Japanese institutions who distribute their records to OCLC is how they can meet international standards. Even with the adoption of Unicode as a solution to the problems associated with the Japanese character set, for example, obstacles remain in the exchange of data and the creation of Web-based 
catalogs such as Webcat provided by NII. The introduction of Unicode has made the bibliographic records of OPACs relatively accessible, but it is still difficult to use Japan originated bibliographic records for catalogs in other countries. The issue of content and its designation is one of the major problems, because of differences in cataloging practices and the characteristics of the Japanese language (Drake, 2005).

Currently, none of NACSIS, TRC MARC, or JAPAN/MARC is compatible with the MARC 21 format. In fact, "while OCLC is the most international of all networks in cooperative cataloging, its requirement to use AACR2 makes it less attractive for some countries" (Holley, 1993, p.203). In libraries in China, Japan, and Korea, catalog records consist of vernacular characters without Romanization; thus, 880 fields are not used. These records, therefore, do not meet OCLC standards and cannot be entered into WorldCat (Chang, 1998).

NII's NACSIS-CAT, the cataloging network system that most university libraries in Japan use, is similar to OCLC in terms of cataloging practice, and similar to MARC for the copy-cataloging that the member libraries can do. As of 2005, NACSIS-CAT participants total 1,036 organizations in Japan. Of these, 644 university libraries participate. For the overseas organizations, there are 23 institutions from Europe, 43 from Asia, and 2 from the U.S (NII's presentation document from CEAL CKM Meeting, 2005). Of these overseas organizations, the British Library as well as the UK Union Catalog have been taking the cataloging service from NII since 1991, while previously they had downloaded many thousands of records in JAPAN/MARC, a very different format that is not capable of being automatically uploaded to NII. The British Libraries 
actually adopted MARC 21 as its cataloging format in June 2004, and there has been no more development of UKMARC since then. "NII's NACSIS-CAT download format has been reshaped into a form which UK's union catalog database software called "allegro" can handle" (Helliwell, 2006, p.5). Similarly, a new partnership between OCLC and NII launched the "GIF Project" in 2002, although this is mainly for an ILL system, not for cataloging. The number of participants from North America is forty, and one hundred from Japan as of September 2004 (Niimoto, 2004).

\section{Issues of AACR2 and LCRI for CJK Cataloging}

For the descriptive cataloging for CJK materials, more detailed discussion of the AACR2 and LCRI guidelines for punctuation and wording for authority names, including personal, cooperate, and titles, is needed. Although the current research on CJK cataloging has become more intensive, there has been little discussion about the complexity and inconsistency of Japanese cataloging which follows the descriptive cataloging rules of AACR2 and LCRI. Possible pitfalls or reasons for retrieving unwanted search results might include certain tag variations in catalog record headings, which tend to be ignored. A corporate name, which is used as a main entry in a bibliographic record, $110,610,710$, or 810 field tends to be improperly used as a personal name MARC 100 field, because there are many Japanese company or institutional names which are exactly same as personal names and geographic names. There are five cataloging issues which tend to be used inconsistent ways.

Issue 1: Portion of title. The issue of portion of title needs to be investigated, since not every OCLC record follows the guidelines specified in LCRI $21.30 \mathrm{~J}$ and 
AACR2 1.1B1, especially for the Japanese monographs with long titles. Portion of title proper mentioned in LCRI 21.30J, needs to contain an alternative title meeting the following requirements: 1) the complete title proper (245 field title added entry), 2) the first part of the title proper up to the word "or" or its equivalent in another language (246 field title added entry), then 3) the part following the word "or" or its equivalent in another language (246 field title added entry). In the case of the examples shown below, since these monographs have long titles, the last half of each title needs to be in the added entry 246 field instead of in subfield \$b of the 245 field. 
Example Record 1

1001 島田神助, d 1956-

1001 Shimada, Shinsuke, d 1956-

24510 ご飯を大盛りにするオバチャンの店は必ず繁盛する: b 絶対に失敗しないビジネス経 営哲学

/c 島田神助.

24510Gohan o ōmori ni suru obachan no mise wa kanarazu hanjōsuru : b zettai ni shippaishinai bijinesu keiei tetsugaku / c Shimada Shinsuke.

260 東京: b 幻冬舎, $\mathrm{c} 2007$.

260 Tokyo : b Gentosha, c 2007.

300164 p. ; c $18 \mathrm{~cm}$.

4400 幻冬舎新書; $\mathrm{v} 039$

440 0Gentosha shinsho ; v 039

650 0Small business.

650 0Success in business.

6500 Creative ability in business.

Example Record 2

\section{1 境祐司}

1001 Sakai, Yuji.

245 10「XHTML マークアップ\&スタイルシート」リフォームデザインガイドブック: b 「Web 標 準」を学びたい Web デザイナーのための指南書。

245 10Ekkusueichit iemueru mākuappu ando sutairu sh ito rifōmu dezain gaidobukku : b uebu hyōjun o manabitai uebu dezainā no tame no shinansho.

260 東京: bソシム, c 2005。

260 Tokyo : b Soshimu, c 2005.

300231 p.; c $26 \mathrm{~cm}$.

500 XHTML + CSS2 対応

65007 ホームページ $2 \mathrm{jlabsh} / 3$

65007 Homu peji. 2 jlabsh $/ 3$

650 07Daburyudaburyudaburyu. $2 \mathrm{jlabsh} / 3$

65007 プログラミング(コンピュータ) $2 \mathrm{jlabsh} / 3$

650 07Puroguramingu(Konpyuta). 2 jlabsh/3

Issue 2: Word division. Word division, so-called wakachi-gaki for Japanese is complicated and needs to be clarified in detail, since some bibliographic records use inconsistent Romanization rules. Romanization of the Japanese vernacular phrase 
therefore is confusing for many CJK catalogers. "Because the catalog provides information on a wide variety of disciplines and subject areas, the vocabulary is diffuse. All these factors make the catalog a difficult tool to use, even for experts" (Connell, 1991, p.229). ALA/LC Romanization Tables 4: Proper Names (a) (ALA-LC Romanization Tables, p.81) says, write proper names and titles of books separately from modifiers or words modified by them. The examples below are the bibliographic files for books on the Japanese traditional art of flower arrangement (Kadō). There are several different schools practiced in history such as Sōgetsu and Ohara. What the author would like to explain here is that the use of hyphenation and word-division for these particular cataloging records are still inconsistent. Based on this rule, Ohara and ryū (meaning school) can be separated. The next rule is whether this Japanese word needs to be hyphenated. ALA-LC Romanization Tables, 4 (a) (4) (p.82) states: hyphenate single characters which can be suffixed to any proper names; 的 (teki), 型 (kata or gata), 式 (shiki), 流 (ryū), 産 (san), 製 (sei), 派 (ha), 系 (kei), 本 (hon), 版 (han or pan), for example. In this case, ryū (流) can be applied to this cataloging rule, and the words Ohara and ryū are shown as Ohara-ryū (see Example Record 1) not Ohararyū (see Example Record 2). When searching the LC Catalog, Ohara-ryū hits a higher rate of retrieving results than Ohararyū. However, for the term Sōgetsu ryū, Sōgetsuryū hits a higher rate of search result than Sōgetsu-ryū. Both the LC and OCLC WorldCat search were done with keyword $(\mathrm{kw})$ search. 
Table 9

Search Results: OCLC WorldCat v.s. LC Catalog

\begin{tabular}{|c|c|c|c|c|}
\hline & Sōgetsury $\bar{u}$ & Sōgetsu-ryy & Oharary $\bar{u}$ & Ohara-ryy $\bar{u}$ \\
\hline OCLC Connexion & 11 records & 10 records & 12 records & 38 records \\
\hline LC Catalog & 9 records & 1 record & 1 record & 9 records \\
\hline
\end{tabular}

\begin{tabular}{|c|c|c|}
\hline & 草月流 & 小原流 \\
\hline OCLC Connexion & 9 records & 27 records \\
\hline LC Catalog & 0 & 1 record \\
\hline
\end{tabular}

Example Record 1

\begin{tabular}{|c|c|}
\hline 040 & _ a MH-HY $\mid \mathrm{c}$ MH-HY $\mid \mathrm{d}$ CStRLIN \\
\hline 050 & 4_la SB450.5.O22 lb O43 1996x \\
\hline 066 & c $\$ 1$ \\
\hline 100 & 1_ a Haneda, Sei, |d 1932- [from old catalog] \\
\hline 245 & $\begin{array}{l}00 \mid 601 \text { la Ohara-ryū shi : |b Ohara-ryū sōryū hyakushūnen kinen shuppan / |c } \\
\text { [hensha Ohara Ryūshi Hensan Jikkō Iinkai]. }\end{array}$ \\
\hline 245 & $\begin{array}{l}00|601| \mathrm{a} \text { 小原流史 : | b 小原流創流百周年記念出版 / } \mid \mathrm{c} \text { [編者小原流史編纂実行 } \\
\text { 委員会]. }\end{array}$ \\
\hline 260 & |6 02 |a Tōkyō : |b Ohara-ryū, Zaidan Hōjin, |c Heisei 8 [1996] \\
\hline 260 & $|602| \mathrm{a}$ 東京 : | b 小原流, 財団法人, |c 平成 8 [1996] \\
\hline 300 & a 2 v. : |b ill. (some col.); $\mid \mathrm{c} 27 \mathrm{~cm}$. \\
\hline 650 & _0_|a Flower arrangement, Japanese $\mid \mathrm{x}$ Ohara school $\mid \mathrm{x}$ History. \\
\hline 710 & 2_|603 |a Ohara Ryūshi Hensan Jikkō Iinkai. \\
\hline 710 & 2_|603|a 小原流史編纂実行委員会. \\
\hline
\end{tabular}


Example Record 2

\begin{tabular}{|c|c|}
\hline 100 & I_ 6 880-01 |a Ohara, Hōun, |d 1908- \\
\hline 245 & $10 \mid 6$ 880-02 |a Ohararyū ikebana / |c Ohara Hōun, Ohara Natsuki. \\
\hline & |a Tōkyō : |b Shufu no Tomosha, |c Shōwa [1984] |g (Heisei 5 [1993] printing) \\
\hline 300 & a 313 p. : |b ill. (some col.); |c $22 \mathrm{~cm}$. \\
\hline 440 & $0 \mid \mathbf{6}: 880-03$ |a Karā dokushū \\
\hline 650 & $0 \mid \mathbf{a}$ Flower arrangement, Japanese $\mid \mathbf{x}$ Ohara school. \\
\hline 700 & 16 880-04 |a Ohara, Natsuki, |d 1949- \\
\hline 880 & I_ 6 100-01/\$1 |a 小原豊雲, |d 1908- \\
\hline 880 & $10 \mid 6$ 245-02/\$1 |a 小原流いけばな/ $\mid \mathbf{c}$ 小原豊雲-小原夏樹. \\
\hline & $\begin{array}{l}\text { of } 6 \text { 260-00/\$1 |a 東京: |b 主婦の友社, |c 昭和 } 59 \text { [1984] |g (平成 } 5 \text { [1993] } \\
\text { orinting) }\end{array}$ \\
\hline 880 & $0|6440-03 / \$ 1| a$ カラ一独習 \\
\hline 880 & _ 6 700-04/\$1 |a 小原夏樹, |d 1949- \\
\hline
\end{tabular}

Issue 3: Romanization. Another confusion often found in some bibliographic records is Romanization of foreign terms that are written in Japanese katakana and roman-ji. As shown in the examples below, some records have inconsistent use of the ALA-LC Romanization tables (1997 edition), especially for the Romanization for Japanese words (written in katakana) of foreign origin. Both records below have their titles regarding a musical instrument violin, but Romanized differently, “バイオリン” and “ヴァイオリン.” According to the American National Standard System for the Romanization of Japanese (ANSI Z39.11), “ば” needs to be Romanized as “ba," and “ヴァ” as "va." Moreover, the name of the author, William Shakespeare can be written in various ways, but it needs to be consistent in order to avoid the less accurate search result. When searching the authority name file of Shakespeare by using vernacular script, 
there is more than one record found in OCLC WorldCat, as shown in the table below, and they are pretty inconsistent.

Table 10

OCLC WorldCat Search Results of Shakespeare in Japanese Roman-ji

\begin{tabular}{|l|r|r|r|r|}
\hline Search Type & シェークスピア & シェイクスピア & シェークスピヤ & シェークスピヤ \\
\hline Keyword $(\mathrm{kw})$ & 228 & 1,582 & 2 & 288 \\
\hline Name $(\mathrm{au})$ & 132 & 399 & 2 & 53 \\
\hline
\end{tabular}

Example Record 1

24500 海峡を渡るバイオリン.

24510Kaikyō o wataru baiorin.

260 東京: b 河出書房新社, c 2007.

260 [S.l.] : b Kawadeshobōshinsha, c 2007.

300429 p. ; c $15 \mathrm{~cm}$.

4400 河出文庫; v 4-1.

440 0Kawade bunko ; v 4-1

60010 陳昌鉉, d 1929-

60014Chin, Shōgen, d 1929-

650 0Violin makers z Japan v Biography.

65007 バイオリン $2 \mathrm{jlabsh} / 3$

65007Baiorin. 2 jlabsh/3 
Example Record 2

24510 ヴァイオリンとギターの演奏 : $\mathrm{b}$ 弦楽器のなかまたち/ $\mathrm{c}$ 池辺晋一郎監修; 三木好良執筆.

245 00Baiorin to gitā no ensō : b Gengakki no nakamatachi / c Ikebe, Shin'ichirō;Miki, Akira.

260 東京: $\mathrm{b}$ 文研出版, $\mathrm{c} 2008$.

260 Tōkyō : b Bunkenshuppan, c 2008.

30040 p. ; c $29 \mathrm{~cm}$.

4400 はじめての楽器.

4400 Hajimete no gakki.

500 付属資料:錄音ディスク $(1$ 枚 $12 \mathrm{~cm})$

65007 弦楽器 $2 \mathrm{jlabsh} / 3$

65007 Gengakki. 2 jlabsh/3

Issue 4: Parallel record. Another question that needs to be investigated in this study regarding the issue of the current cataloging practice of $\mathrm{CJK}$ materials is whether the MARC records need parallel fields in each record showing both the transliterated Romanized field and vernacular data at the same time. Transliteration is the process of converting the characters of an alphabetical or syllabic script to the characters of a conversion alphabet. Transliteration is not suitable for ideographic characters such as CJK, because their transliterations into alphabets are identical and therefore lose their meaning (Haddouti, 1999). In fact, in the Connexion client, non-Latin script records are allowed to have vernacular data only, or Romanized data only. "The vernacular script only also helps to reduce a barrier to international student access, since the students from other countries have various levels of knowledge on the use of an American academic library" (Zhuo, Emanuel, and Jiao, 2007, p.10). This implementation departs from the convention that non-Latin script records must contain bibliographic data in paired vernacular and Romanized fields. Such records literally do not have Roman access 
points, thus cannot be found by Latin searches (Wang, 2005). As shown in the example of OCLC MARC bibliographic records, 100, 245, 250, 260, 490, and 700 fields have parallel records in both vernacular and Romanized characters. One of the advantages of having parallel fields is to provide more capacity for foreign resources, and access points for retrieval. On the other hand, this new feature brings in increased complexity in cataloging. The announcement of using parallel records was made by OCLC in October 2003 (OCLC, 2003), in the Technical Bulleting 250 (TB250). It means that libraries where English is not the language of the cataloging agency can now legally add new records for the same title that already has bibliographic records (Bolick, 2004). This new format is called the hybrid record. The one thing catalogers need to be careful with is not to mix up with the language code in fixed field with the language of the materials cataloged and the language code in 040 field. To the CJK catalogers and specialists who have been cataloging CJK language materials based on AACR2 cataloging rules, OCLC online cataloging is complying with the AACR2 2002 revision and the language of cataloging is English. That means that it is not necessary to enter the 040 subfield $\$ \mathrm{~b}$ (Kotaka, 2003). For the records originally cataloged in WINE MARC which is based on JAPAN/MARC format used to contain $040 \$ b$ jpn even after the WINE record format was converted into the OCLC MARC format (Kotaka, 2003). However, starting with March 2008, OCLC users will no longer see the language of cataloging code "jpn" in the 040 field in WINE MARC records, according to Kotaka's OCLC CJK Users Group Discussion (Kotaka, 2008). 
The most recent version of AACR2 has a few chapters stating the retention of the original non-Roman scripts as follows.

Chapter 1 (General Rules for Description)

1.0 E. Language and script of the description

1.0 E1. In the following areas, give information transcribed from the item itself in the language script (wherever practical) in which it appears there: Title and statement of responsibility, Edition, Publication, distribution, etc. and Series. In general, give interpolations into these areas in the language and script of the other data in the area. Exceptions to this are a) prescribed interpolations and abbreviations, b) general material designations, c) supplied forms of the place of publication, and d) statements of function of the publisher, distributor, etc. (AACR2, 2005, 1-8).

Chapter 22 (Heádings of Persons)

22.3 C. Names written in a non-Roman script

$22.3 \mathrm{C} 1$. Persons entered under given name, etc.

If no English is found, or if no one Romanization predominates, Romanize the name according to the table for the language adopted by the cataloging agency (AACR2, 2005, 22-11)

22.3 C2. Persons entered under surname

If the name of a person entered under surname is written in a non-Roman script, Romanize the name according to the table for the language adopted by the cataloging agency (AACR2, 2005, 22-12). 
Chapter 24 (Headings for Corporate Bodies)

24.1B. Romanization

24.1 B1. If the name of the body is in a language written in a nonRoman script, Romanize the name according to the table for that language adopted by the cataloging agency. Refer from other Romanization as necessary (AACR2, 2005, 24-5).

Chapter 25 (Uniform Titles)

25.2 D. Romanization

25.2 D 1 . If the title selected as the uniform title is in a language written in a non-Roman script, Romanize it according to the table for that language adopted by the cataloging agency (AACR2, 2005, 25-6). Retaining the CJK original vernacular scripts is one of the issues discussed in this study. The question is whether the information in the 245 and 260 fields of CJK records needs to be retained whether in Roman, vernacular, or both.

Issue 5: Vernacular search. As discussed in the latter chapter of this study, the survey research shows that some libraries' OPAC supports both input and display of the CJK vernacular scripts, which help library users to locate and retrieve their sources more precisely. A few cataloging librarians comment that they have received online requests from their patrons for materials in CJK languages, and they are taking advantage of their multilingual OPAC. However, there are still several areas which need further attention if OPAC's are to be able to be fully searchable and display all the CJK characters. In order to help meet the library needs of non-native English speakers, as well as those who are specialized in Japanese-related studies in U.S. academic settings, for example, some library bibliographic records or databases have their interfaces and search functions use 
the original Japanese scripts. Search results would also contain vernacular scripts. This function appears to help the bibliographic databases of the OPACs to many assist library users of today. In other words, it allows users to input, retrieve, and display the CJK characters. CJK vernacular scripts have provided more accurate bibliographic information in many U.S. libraries, and so handling these non-Roman scripts in the system is quite important. Since Romanization for Japanese terms tend to be problematic, using vernacular scripts help reduce reliance on Romanization. It is mainly because there are many Japanese words that are pronounced the same way, but have quite different meanings. For example, the Japanese term "hana" can be written as 花 (means flower) and 鼻 (means nose). The other thing that needs to be noted here is that when the reading is different, although they are written with the same Japanese kanji, the names could be recognized to be those of different persons (Harai, 2007).

OCLC uses the original catalogs created by Waseda University Library, and adds the Romanized lines to the ones in Japanese transcripts. Many users might have already noticed the CJK materials held in many U.S. libraries include CJK characters, which enables users and library staff to search for CJK materials using only vernacular original scripts in the query.

Controlled vocabulary (authority name) of each bibliographic record is used to analyze its problems and the effectiveness of searching. It is also meaningful to do this since "a bibliographic database cannot be evaluated in isolation but only in terms of its value in responding to various information needs" (Lancaster, 1991, p.116). It is also meaningful to examine the headings of Japanese names, especially Japanese authors with 
various names, such as pen names, pseudonyms, and other types of names, under a single record. The search types used in LC Authorities are divided into several categories including subject authority headings, name authority headings, title authority headings, and name or title headings.

Table 11

Authority Headings Search, Library of Congress Authorities

\begin{tabular}{|l|l|}
\hline Search Type 1 & Name Authority Headings \\
\hline Search Type 2 & Title Authority Headings \\
\hline Search Type 3 & Name/Title Authority Headings \\
\hline Search Type 4 & Keyword Authorities \\
\hline
\end{tabular}

Non-Latin script vernacular records without Latin script transliteration in parallel Romanized fields can be entered into the LC and OCLC WorldCat databases, and these databases now seem to operate without any serious problems. Both the OCLC and LC library cataloging systems have been enhanced to help users access CJK vernacular records, and they are no longer severely limited in access compared to Romanized search methods, which were common before. "Transliterated names may be desirable as an added access point for staff and others unfamiliar with the original script, but they are no substitute for access via the original script when the convenience of the catalog user as its first objective" (Agenbroad, 2006, p.29-30). "Online catalog records that include rich content details in the East Asian scripts offer consonant [sic] ease in browsing and intellectual access" (Hickey, 2006, p.79). For these reasons, single records for non-Latin 
vernacular script could be created rather than having a parallel Romanized field in the sáme record. This study hopes to clarify how the use of vernacular search effectively helps the precision of information retrieval.

For keyword searching on LC authority files, the $1 \mathrm{xx}, 4 \mathrm{xx}, 5 \mathrm{xx}$, and $7 \mathrm{xx}$ fields are used. The MARC 21 field 880 is also one of the important character sets used for nonLatin materials. This field is for alternate graphic representation, but it does not display in online WorldCat records nor on work forms that catalogers use, since for machineprocessing reasons the non-Latin script fields are stored internally (OCLC, 2007). The data it contains appears online in the field linked by subfield $\$ 6$ as a "linkage" (OCLC, 5:9). Linking tag is the tag number of the associated field. This part is followed by a hyphen and the occurrence number in two digits which could be assigned at random for each set of associated fields. Occurrence number is followed by a slash as seen in the example below.

Example Record

$24510|6880-02| \$ a$ Futari dake no kyōsōkyoku/|\$c Akagawa Jirō. Yokota Junya. 8801 1 6 100-01/\$1 |a 赤川次郎, |d 1948$88010|6245-02 / \$ 1| a$ 二人だけの競奏曲 / $\mid \mathrm{c}$ 赤川次郎, 横田順彌. $880 \_|6260-03 / \$ 1| a$ 東京 : $\mid b$ 講談社, $\mid c$ 昭和 59 [1984] 880 1_|6 700-04/\$1 |a 横田順彌, |d 1945-

The occurrence number of $\mathrm{CJK}$ materials is $\$ 1$. In addition, the 880 field is not used in authority records for non-Latin scripts, even though the general practice for bibliographic records in the Anglo-American context has to follow MARC 21's Model A (Roman script data in regular MARC fields, non-Latin script data in this field that parallels regular MARC fields). At the same time, the 880 fields represent the content of 
another field in the same record in an alternate script. The 880 subfield $\$ 6$ links the alternate script field to its corresponding field and provides information about the alternate script. The 245 field subfield $\$ 6$ indicates that there is a corresponding 880 field in an alternate script as well (Tull, 2004). Authority records can be encoded in UTF-8. Thus, authorities need to use MARC 2l's Model B for multi-script records, where nonLatin script data is entered into the same MARC tags as Romanized data, and the nonLatin fields are not linked to parallel Roman fields.

The search results contain vernacular scripts as well, so that the search result can be more accurate than using Romanized letters. In the case of Japanese names, there are many names especially for the author names having more than one character. It commonly happens in Japanese literature published before the mid- $20^{\text {th }}$ century.

Since the name authority control for the author's name is important as an effective method of library catalog search, it always needs to be consistent in format. Authority control for the name headings including author's name and geographic names, for example, without showing vernacular scripts in the bibliographic record, also tends to cause some problems. If the names are written in Romanized characters only then it is hard for users to identify the actual records. This is mainly because there are many Japanese words with the same pronunciation but different meanings. Also, not every Japanese record of the LC catalog has a parallel record of vernacular and Roman characters in a single record (see Example Record below). For instance, the LC authority file will not have paired records for Latin script and non-Latin script forms of name headings for the same entry, according to the OCLC's documentation for International 
Cataloging. The paired fields in Connexion work forms for multi-script bibliographic data are $1 \mathrm{xx}, 245,246,250,260,300,4 \mathrm{xx}, 5 \mathrm{xx}, 6 \mathrm{xx}$, and $8 \mathrm{xx}$. One possible improvement for this is to have more standardized formats and rules of the name authority records in CJK in other Asian countries besides in the CJK library community in the U.S. In other words, name authority control needs to have a more universal approach, so that catalogers in each language can keep up with all the changes and updates.

\section{Unicode}

A clear understanding of how multilingual bibliographic records can be created and used for libraries needs to be mentioned here. Coyle and Aliprand discuss the use of Unicode in developing a library's bibliographic database with a multi-script capability in various languages. The ASCII code, which is the main key character set in use today, has thirty-three control characters, thirty-three punctuation marks and symbols, upper and lower case alphabetic characters, and numbers (0-9), to make a total of 128 characters. The ASCII code set is most commonly used for European languages, especially for English, but it is not enough to represent languages other than English, since there are still some limitations using the 128 choices provided by seven of the eight bits in a byte. More letters are needed to represent other languages. In order to meet the requirements of other European languages in computer operating systems, IBM created "code pages," which helped make use of the entire byte, all eight bits. This means that a total of 256 different characters became possible to use. Even though 256 different characters were not sufficient to cover all the Western languages, each code page covered one language 
(Greek or Cyrillic, for example) or a family of languages such as Slavic whose alphabetic characters could be assigned codes without exceeding the limit of 256. "The extension to 16-bit was crucial in allowing a representation of 65,000 characters" (Haddouti, 1999, p.13). In the middle of the $1980 \mathrm{~s}$, the International Standards Organization (ISO) developed ten 8-bit character set standards that defined encodings for languages similar to the proprietary code pages. The first of these standards is called ISO 8859-1, known as "Latin-1" or "Extended Latin," covering the original ASCII character set as well as some special characters. Other ISO 8859 standards are used for Cyrillic, Arabic, Greek, Hebrew, and some other East European languages. However, these ISO 8859 standards still did not fully cover East Asian language ideographic characters such as Chinese and Japanese, since the number of the characters available in an eight-bit system was only 256. The Japanese hiragana and katakana using only fifty characters each, worked without disturbing the ASCII characters. Kanji (Chinese characters) were more challenging because they include more than six thousand characters. The Japanese Information Standard (JIS), therefore, defined a two-byte character encoding for kanji. It used only bytes that had not been defined in standard ASCII, so rather than having the ability to express $256 * 256$ codes $(65,356$ possible values), it used two bytes of ninetyfour values each, giving a total of 8,836 possible unique values. Some characters and ideograms require more than a two-byte sequence. In this situation, the idea of "Unicode", was first used in late 1987, to encode various languages. ISO then created a universal character set (UCS) standard, ISO 10646. "ISO also later extended the size of 
the character set to four bytes so that some of the limitations in Unicode's two-byte code can be overcome" (Coyle, 2005, p.591-592).

Machine Readable Cataloging (MARC), originally developed by Henriette Avram of LC in the early $1960 \mathrm{~s}$, provides a mechanism by which computers exchange, use, and interpret bibliographic information, and its data elements make up the foundation of most library catalogs used today. MARC became USMARC in the 1980s and MARC 21 in the late 1990s. MARC21 is a combination of both USMARC (by the Library of Congress) and CAN/MARC (by the National Library of Canada) to harmonize each function. The Library of Congress established one of the world's largest name authority files using this MARC21 standard (Lam, 2002). The name both points to the future as we move into the 21 st century and suggests the international character of the format, which is appropriate and important given its expanding worldwide use. LC also explains that MARC 21 records are intended for broad, standard interchange and work with two character encoding schemes (LC, December 2007). This is how MARC 21 records work in the MARC-8 encoding environment.

As the capabilities of both computer display and of printing from computers progressed, new methods were added to the MARC record and the cataloging systems used by libraries to encode some non-Latin-based alphabetic languages, such as Greek or Russian, as well as the ideograms of Chinese, Japanese, and Korean. In libraries in the U.S., these non-Latin characters are generally encoded in special fields in the MARC record, the 880 fields, "Alternate Graphic Representation." "The 880 fields, therefore, help display the vernacular languages of the works while the search and sort functions 
make use of the transliterated form of the headings" (Coyle, 2006, p.101). Since the number of character sets and symbols of MARC-8 is much smaller than that of Unicode, applying the idea of Unicode to the library's cataloging systems makes it possible for library catalogs to more easily display all works in their own vernacular scripts. However, the transition from the currently approved MARC-8 character set which has still been used in many U.S. libraries' metadata today, to a Unicode-compliant library system, is an issue. Compatibility between MARC-8 and Unicode is one of the reasons for this. On the other hand, Coyle mentions that the technical change of catalog records from MARC-8 to Unicode is not a complex nor lengthy process, because translation tables that can be manipulated by computer programs available on the Library of Congress Web site, and modern computer languages, such as C, Java, Python, and Perl, are able to work directly with the Unicode character set, as are today's Web browsers, such as Netscape $6.2+$ and IE 6.0+. At the same time, incoming MARC 21 records in MARC-8 format will be converted during the input process. "LC started converting their records to Unicode in 2003, and the MARC Distribution Service will continue to provide records in MARC-8 but will also offer records in UTF-8" (Tull, 2004, p.8). Software vendors such as Endeavor Information Systems Inc. (EISI) have supported LC, and many other U.S. libraries, for the Unicode conversion. The Voyager system is a good example of this designed by EISI. LC has begun working closely with EISI on its database conversion process. The first conversion of an LC database was done in January 2003. 31.7 million records, including 500,000 records with 880 tags, were converted to Unicode (Yao, 2003). Additionally, LC will continue to record non-Roman scripts in 880 fields, 
even though their software will enable them to record non-Roman scripts anywhere in a MARC record (Porta, 2005). However, Aliprand points out that, in viewing an authority record, Romanization cannot be substituted for original script data because a cataloger needs to see everything. "Pairing of Romanized and non-Roman fields in authority records is not needed. Because the complete record must always be seen, whether 880 fields need to be used in authority records is questionable" (Aliprand, 2005, p.247).

Aliprand discusses in detail the effects of Unicode, as she specifically analyzes what the structure of the record needs to be when a record is encoded in Unicode rather than in the individual character sets, so-called MARC-8. As of December 2005, "the Association for Library Collections \& Technical Services (ALCTS), Library Information \& Technology Association (LITA), and Reference and User Services Association's Machine-Readable Bibliographic Information Committee (MARBI) continues to work on the technical requirements for the use of Unicode in MARC 21" (Aliprand, 2005, p. 170). The East Asian Character Set Task Force, established in 1997, finished their mappings from EACC to Unicode in 2001 resulting in Proposal 2001-2009, Mapping of EACC Characters to Unicode/UCS (LC, Proposal 2001-09).

Unicode actually specifies three encoding forms. One of them is called UTF-8 which is authorized for use in MARC 21 bibliographic records. UTF-8 transforms a full 32-bit representation of Unicode code points, or the original 16-bit representation of Unicode (UTF-16), into 8-bit units. A Unicode character can be represented in a single octet, which is a series of eight bits to form a single byte, or a sequence of two, three, or four octets (Character Sets, LC). There are several different coding mechanisms between 
MARC-8-encoded and Unicode-encoded MARC 21 bibliographic records. First of all, Leader/09, a character code scheme, which contains a one-character code, needs to be coded in different ways. For MARC-8-encoded records, there is no value, as indicated as a blank (\#), while for Unicode-encoded records, there is a value $a$. Second, MARC field 066, Character Sets Present, is not used in Unicode-encoded MARC 21 records. This field is system-supplied and identifies the presence of any character sets for non-Latin scripts in the MARC 21 records, and it cannot be deleted, edited, or added (OCLC-007 Introduction). On the other hand, as shown in the two records shown in the next section (Model A and Model B), the MARC field 066 for both models has \$, which means the character set has multiple bytes per character, and 1 next to $\$$. $\$ 1$ means that the record is in the Chinese, Japanese, or Korean vernacular script. In addition, the subfield $t c$ before $\$ 1$ means that a code identifies the alternative character set used in these records (ibid). The OCLC WorldCat database and the database from RLG's Union Catalog (now merged with OCLC) are Unicode compatible. For a long time, LC has added CJK as well as some other non-Latin scripts to their bibliographic records, using the specialized cataloging systems of RLIN and OCLC.

\section{Model A and Model B}

There are two models (Model A and Model B) for the inclusion of CJK metadata in bibliographic records under the format of MARC 21. Model A is good for creating a Romanized record and appending the CJK data in designated fields, while Model B is for transcribing the CJK data directly into regularly tagged fields. "Model A allows any 
library with a system capable of displaying the characters used in ALA-LC Romanization to see a complete record, while Model B works only for libraries with devices capable of displaying CJK" (Aliprand, 2005, p. 171).

There are several ways to see whether a CJK bibliographic record is in Model A or Model B. As shown in the following examples, which the author derived from the two different OPACs of certain university libraries, both records have the individual character sets because of the 066 field. All the bibliographic records with CJK characters always include field 066 , which means that the character sets are present. Also, field 066 identifies the non-Roman character sets present in the 880 field, alternate graphic representation. The $\$ 1$ value in subfield $c$ of the 066 field means East Asian Code Character (EACC), while the absence of subfields $a$ and $b$ from the 066 field means that ASCII is the default character set for these records.

Example of Model A

$066 \mid c \$ 1$

1001_ 6 880-01 |a Ōe, Kenzaburō, |d 1935-

24510 |6 880-02 |a Aimai na Nihon no watakushi / |c Ōe Kenzaburō cho.

2463_ a Anbigyuasu Nihon no watakushi

260_ 6 880-03 |a Tōkyō : |b Iwanami Shoten, |c 1995.

300 _a ii, 232 p. ; c $18 \mathrm{~cm}$.

440_0 6 880-04 |a Iwanami shinsho. Shin akaban; |v 375

500 _ a A collection of 9 essays, including the author's Nobel Prize address.

8801_|6 100-01/\$1 a 大江 健三郎, |d 1935-

$88010 \mid 6$ 245-02/\$1 |a あいまいな日本の私 / |c 大江 健三郎著.

880_|6 260-03/\$1 |a 東京: |b 岩波 書店, |c 1995.

$880 \_0|6440-04 / \$ 1| \mathrm{a}$ 岩波 新書. 新 赤版; | v 375 
Example of Model B

$066-\mid c \$ 1$

$100 \overline{1}_{-} \quad 601 \mid \mathrm{a}$ Ōe, Kenzaburō, |d 1935-

$100 \quad 1_{-} \quad 601$ a 大江健三郎, $\mid \mathrm{d} 1935-$

$240 \quad 10 \quad$ a Essays. |k Selections

$245 \quad 10 \quad 602$ |a Aimai na Nihon no watakushi / |c Ōe Kenzaburō cho

$245 \quad 10 \quad|602| \mathrm{a}$ あいまいな日本の私 / c 大江健三郎著

260 — 603 |a Tōkyō : |b Iwanami Shoten, |c 1995

260 - $603 \mid \mathrm{a}$ 東京 : | b 岩波書店, |c 1995

300 - $-\mid$ ii, 232 p. ; |c $17 \mathrm{~cm}$

$490 \_0 \quad 604$ |a Iwanami shinsho. Shin akaban; |v 375

$490 \_0 \quad 604 \mid \mathrm{a}$ 岩波新書. 新赤版 ; | v 375

500 - a A collection of 9 lectures, including the author's Nobel Prize address

$600 \quad \overline{10} \quad 605$ |a Ōe, Kenzaburō, dd 1935-

$600 \quad 10 \quad 605$ |a 大江健三郎, |d 1935-

$650 \quad 0 \quad$ a Humanism

6510 |a Japan |x Civilization |y 1945- 


\section{Methodology}

This research consists of two major components: survey research of selected CJK materials from cataloging librarians, and quantitative and qualitative analysis of the current cataloging practices based on the survey results. In order to obtain meaningful results, one needs to design a method by which each cataloging practice held at libraries can be thoroughly analyzed and evaluated.

According to Creswell's study (Creswell, 2008), the standard components of research method include participants, materials, procedures, and measures. Researcher as a key instrument collects data himself or herself through examining survey result. The purpose of the survey research is to produce statistics, that is, quantitative or numerical descriptions about some aspects of the study population. "The main way of collecting information is by asking people questions; their answers constitute the data to be analyzed" (Fowler, 2008, p.1). "A survey is the research method used to structure the collection and analysis of standardized information from a defined population using a respective sample of that population" (Pickard, 2007, p.95).

With the growth of the internet these days, the format of the survey that has been created via online has some advantages. The higher response rate, the convenience for the participants, and the better efficiency of processing the collected data, are the primary reasons for using online survey, rather than telephone calls or direct emails. The data value was set to be automatically entered into the spread sheet, so that the survey results appeared to be proceeded easily to analyze. All the questionnaires needed to be concise and clear, as surveys should not require a lot of writing. Otherwise, it makes the 
collocation of data more difficult for this study. The survey results were analyzed using quantitative and qualitative methods.

The survey research conducted for this study was based on information derived from a survey among U.S. university libraries in the form of questionnaires via online survey. Respondents were asked to answer the total of twenty-one questions (Appendix) which are primarily multiple choices about the CJK cataloging practices.

The names of the cataloging librarians of these forty-three university libraries and three public libraries are listed in the Committee on East Asian Libraries (CEAL) Directory updated on September, 2008, while those of the remaining five local public libraries were found from the membership directory of OCLC CJK Users Group (updated on March, 2009).

These libraries are located in twelve different states. However, they have major similarities. Each catalogs several thousand monographic CJK titles a month, a process involving a variety of people with different levels of expertise: professional catalogers, para-professionals, and student assistants. The survey questionnaire includes statistics data regarding the number of CJK monographs in the library collection and personnel support of East Asian libraries and collections. Another survey question is about the cataloging process, such as the creation, the correction, and the maintenance of bibliographic records. The last two survey questions cover: 1) Participation in PCC programs (SACO, NACO, and $\mathrm{BIBCO}$ ), 2) What changes are coming to CJK cataloging and how will the cataloging department meet them? Besides the numbers provided in the survey responses, the author was advised to check some of the updated statistics data 
from current CEAL Statistics, although there are some minor discrepancies in the numbers between these results.

Between August 16 and August 24, 2009, the survey questions were sent to fiftytwo libraries. Twenty-three libraries out of the fifty-three queried have responded. Although this 43 percent return rate was slightly lower than expected, the feedback with productive comments turned out to be useful and sufficient to analyze and review the current CJK cataloging facts and practices. 


\section{Survey Results and Case Studies}

In this chapter, the author reviews and discusses the current CJK cataloging practices held in U.S. university libraries, based on the survey results and the case studies which have previously been discussed by the other researchers. The latter especially helped the author to find some criteria for evaluating the CJK cataloging activities practiced by the librarians who participated in this survey. The survey results from this research are organized into seven categories: collection size, cataloging staff, PCC participation, and cataloging features; outsourced cataloging and copy-cataloging; backlogged CJK library materials; transition from RLIN to OCLC; maintenance and update bibliographic records; language competency for catalogers; and changes in cataloging practices. The survey questions are provided in the Appendix section.

\section{Collection Size, Cataloging Staff, PCC Participation, and Cataloging Feature}

The number of East Asian library materials, particularly for monographs written in Chinese, Japanese, and Korean, was surveyed to evaluate and analyze how it reflects the quality control of CJK cataloging practiced at each university library. The author was advised by three survey respondents to refer more accurate number of collection size, backlogged CJK library materials, and cataloging staff to CEAL statistics database (CEAL, 2009). The estimated numbers of monograph volumes (not titles) in each CJK language, as shown in the table below, indicate that the estimated sizes of the professional library staffs do not relate closely to collection development due to the following facts: more outsourcing cataloging services, more library network systems, 
particularly for the Z39.50 communication protocol, and more active participation of cooperative cataloging between various library communities. " $\mathrm{Z} 39.50$ is oriented to a communication protocol system, so-called client/server, which supports searching and retrieval of information in a distributed network environment" (Garrity, 1995, p.12). "Z39.50 (ISO 23950) was produced in the 1980s when US bibliographic utilities and the LC conducted a project, called the Linked System Project (LSP). This protocol has been primarily used for search and retrieve, and provides a standardized way to describe search operations and a way to present the results" (Miyazawa, 2002, p.2). The collection size was categorized as large (more than 100,000 volumes), medium (between 10,000 and 100,000 volumes), and small (less than 10,000 volumes), as in the format used in Hotelling's study (Hotelling, 1994). The recent shared cataloging via library network systems makes it possible for both library staff and users in one system to retrieve and search data from other computer network systems. The OCLC Online Union Catalog, WorldCat, includes information regarding the bibliographic description of a single item or work and a list of institutions that carry each item. That means that each institution is able to share these bibliographic records, using them to create their local library catalogs more efficiently. A typical library technology environment includes multiple interrelated systems, many of which need to access data and functionality from others. This "open system," defined in Breeding's article (2009), includes much library automation software which helps provide access to major categories of library data. Some good examples of standards and protocols developed by libraries are MARC 21 and Z39.59. The latter provides a standard approach for search and retrieval for information systems and has 
been very effective a basis for library applications such as virtual union catalogs and search and selection of MARC records from bibliographic services (Breeding, 2009). This protocol allows a client to search multiple remote servers using a single search interface, and many libraries participating this research survey mentioned that their local cataloging systems are designed to import and copy external bibliographic records from OCLC (via using OCLC Connexion interfaces) using the Z39.50 protocol.

The current automated library system including the copy-cataloging which will be discussed in the latter section of this chapter is one of the key factors affecting the cataloging and technical services. The roles for professional as well as paraprofessional catalogers have been adjusted to these changes which are strongly associated with the today's new development of technologies and software tools used for many libraries. Although these technology changes have not yet dramatically reduced the size of the library staff in most of the libraries surveyed, the libraries try to balance the staffing and the collection size with the new technology tools. 


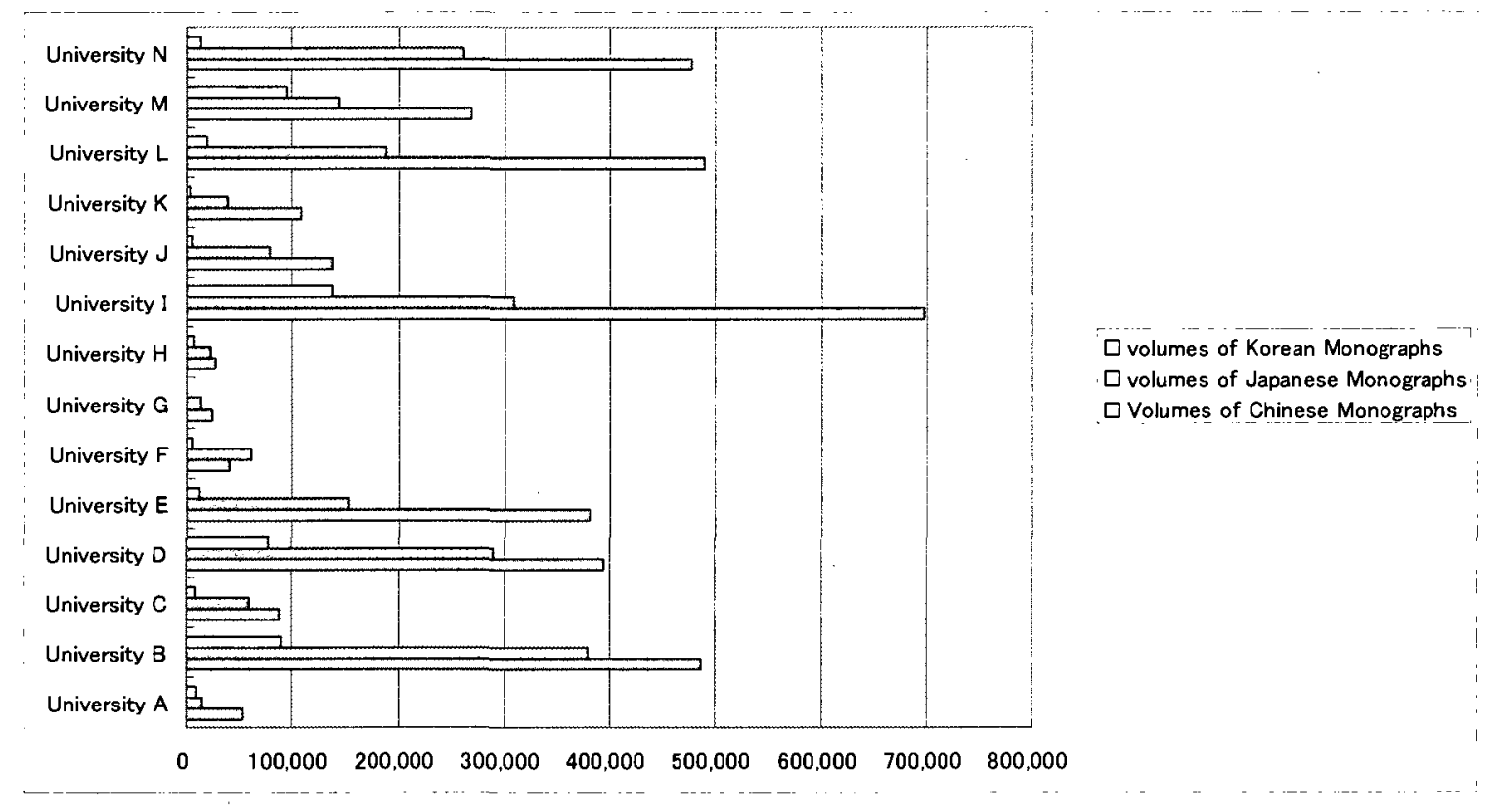

Figure 2. Collection size

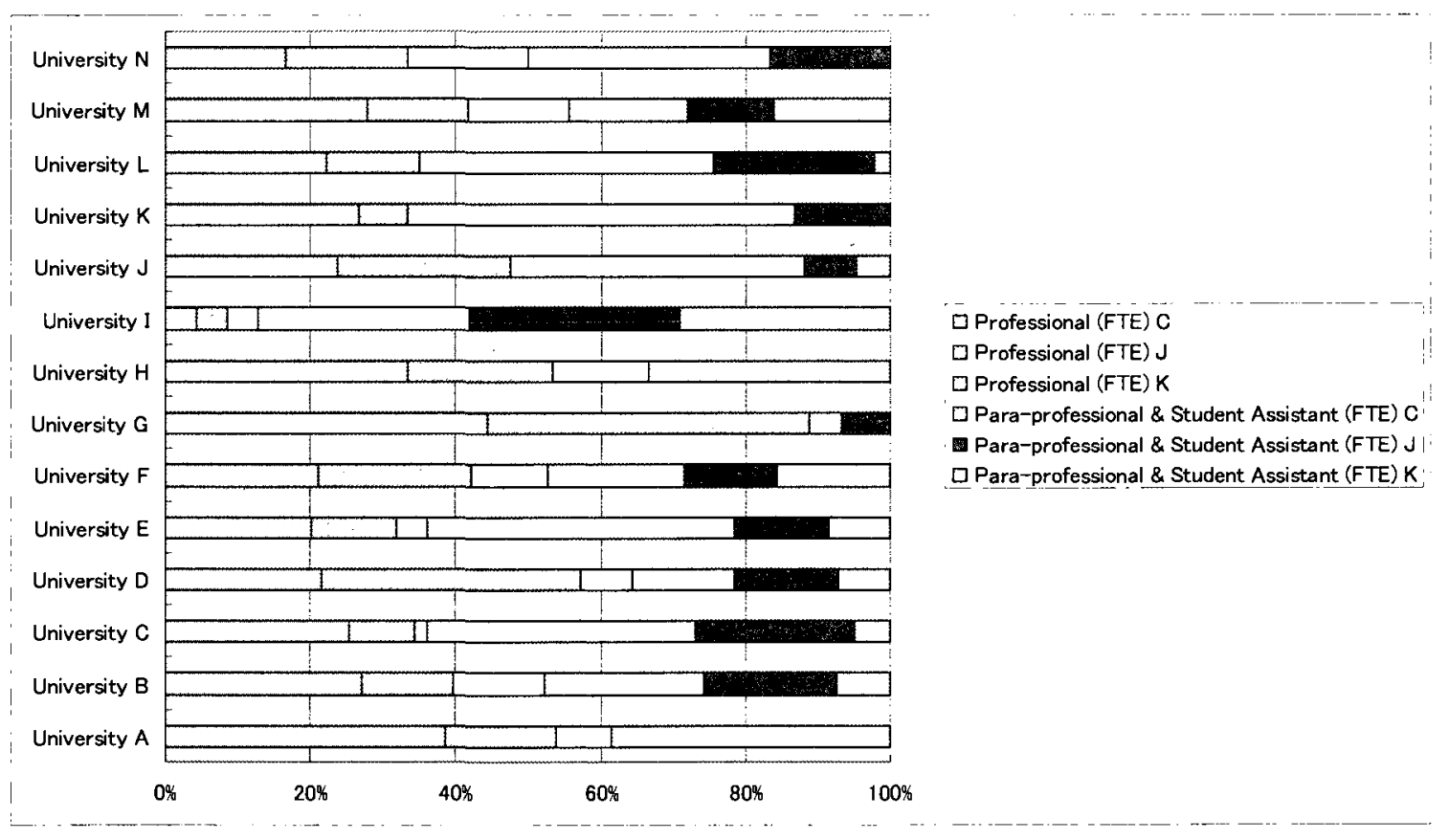

Figure 3. Number of cataloging staff 


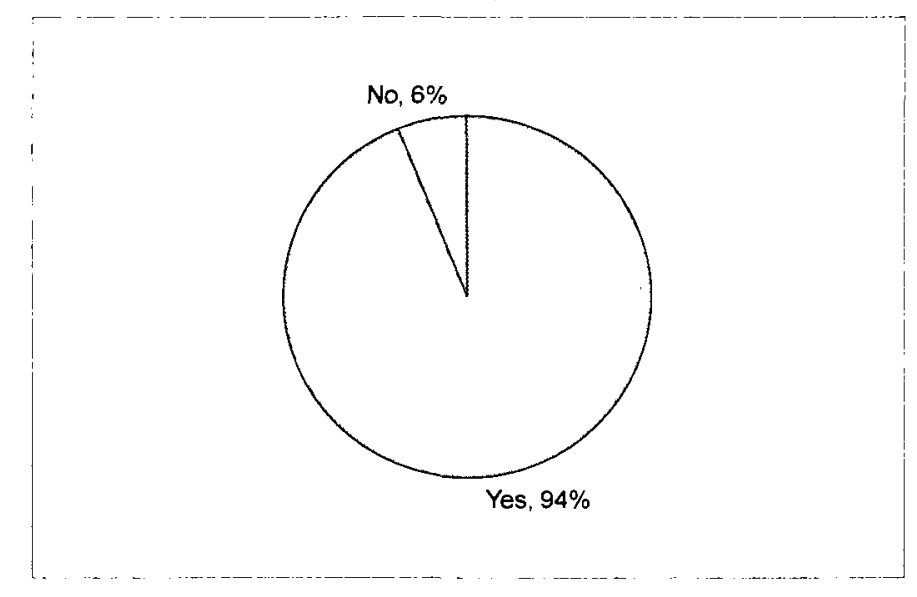

Figure 4. CJK vernacular script (input/display) in OPAC

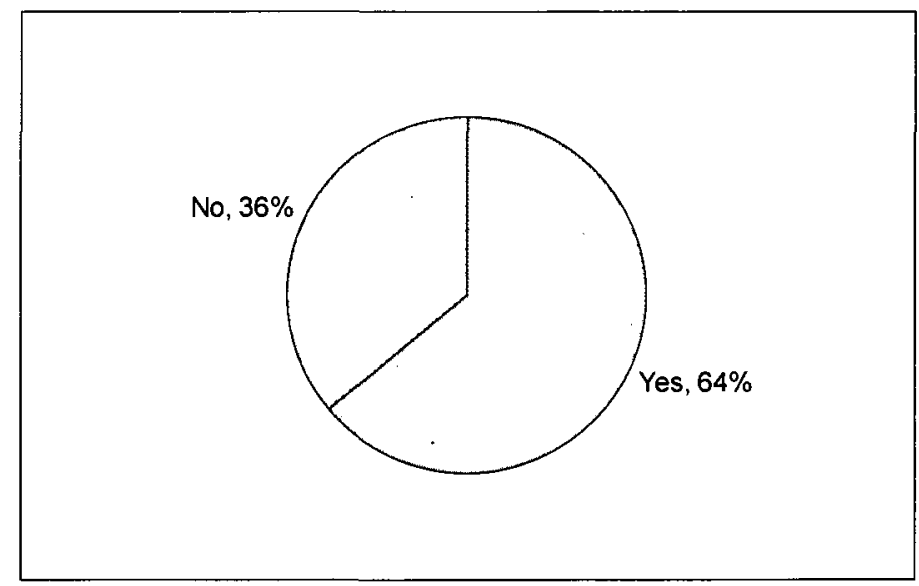

Figure 5. Participation of CJK NACO 


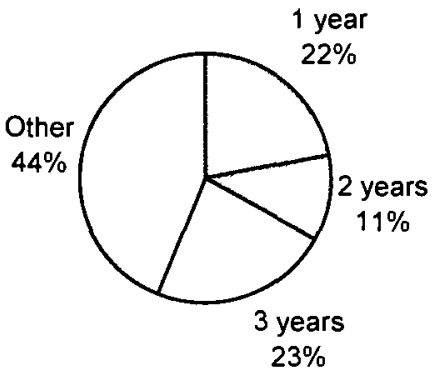

$\square 1$ year

$\square 2$ years

$\square 3$ years

口other

Figure 6. Years in CJK NACO participation

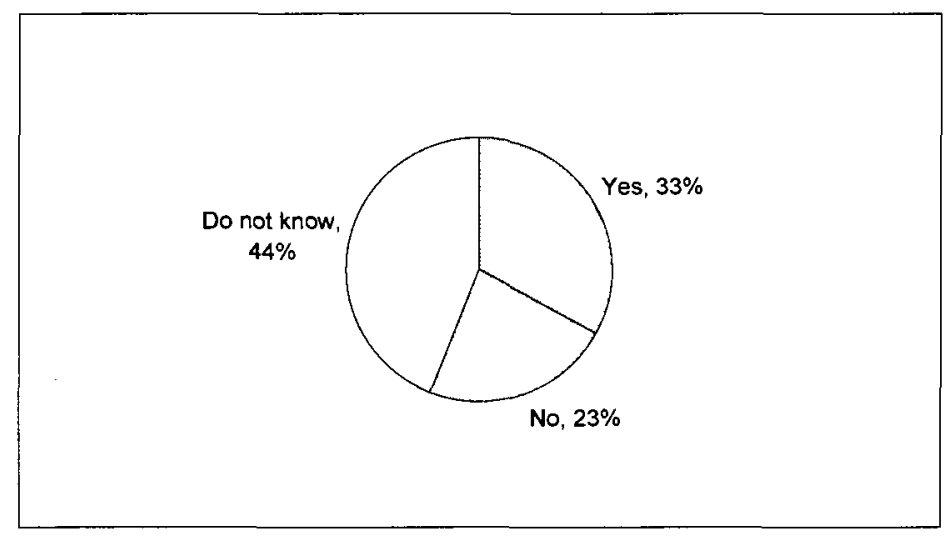

Figure 7. Potential member (within two years) of CJK NACO

\section{Outsourced Cataloging and Copy-Cataloging}

Outsourced cataloging and copy-cataloging are considered by many university libraries these days for several reasons. All fourteen university libraries participating in this survey perform copy-cataloging in house. One cataloger who participated in this survey commented that she occasionally does copy cataloging when a books shows up at her desk. Since these are usually gift books with copy, it is easier for her to do copy cataloging rather than sending it on to another unit for the original cataloging. She also 
supervises a student who does occasional copy cataloging of gift materials. The copy catalogers search for a copy in OCLC and import it into their local bibliographic data system, and edit it if necessary.

Copy cataloging is practiced at many libraries besides the original cataloging "to speed movement of items to the collection and reduce the number of items" (DeZelarTiedman, 2006, p.120). According to the survey results, all twelve libraries do copy cataloging for their daily workflows, besides the original cataloging. Specifically, 93 percent of the responding catalogers perform copy cataloging with OCLC Connexion copy. Of the two national level bibliographic databases, the ones from OCLC and LC, 94 percent of the respondents check first OCLC when searching the titles, while six percent for LC. "Catalogers cope with an ever-increasing work load by relying on copy cataloging from trusted sources. This cataloging is often acquired and reused with minimal revision or no revision" (Denda, 2007, p.267-268). There are a few examples of how the workflow of searching and copy cataloging can be performed. DeZelar's article mentions the outline of the general workflow of the copy cataloging function which is processed at the library of University of Minnesota. One software product they use for their Integrated Library System (ILS), Aleph, which is designed by the company called Ex Libris, a developer of applications for libraries and research institutions, is configured import bibliographic copy from OCLC. Aleph has been used worldwide especially for strong multilingual support of large library collections. The current version of the Aleph integrated library system is 20.0. According to Ex Libris news as of June 4, 2009, over 3400 institutions world-wide use Aleph including Guangdong Provincial Sun Yat-Sen 
Library in China and Keio University in Japan (Library Technology Guides, 2009). Some other popular software that this company provides includes SFX and Voyager. According to the membership list created by Ex Libris Users of North America (ELUNA), there are 313 libraries and library consortia in North America as of May 2009. The current version they use is Aleph500 version 14.2. For the workflow of copy cataloging performed at the University of Minnesota, "first, upon logging in to Aleph's searching module, the user is automatically connected to the local catalog. Then, the user selects an external database such as OCLC. Second, the user executes a search, using the same types of commands available to staff. Third, if appropriate bibliographic copy is found, the user selects the record and moves it to the catalog module. Fourth, in the cataloging module, the user executes the duplicate command, which creates a working copy of the record on the user's hard drive. The user is prompted to select a format type, such as books and serials, and then is able to edit the record as needed, depending on the level of the staff member and the stage in the workflow. Lastly, once a record has been saved to the server, associated orders, holdings, and item records are created as needed" (DeZelar-Tiedman, 2006, p.121). One cataloger from the university $\mathrm{K}$ mentioned that the biggest change for the catalogers in this institution is that they have just agreed to participate in a six month experiment that OCLC is doing to allow all catalogers to enhance OCLC records. To do this, they need OCLC Connexion installed on their computer and do their cataloging directly into OCLC. This will be a good change for them, because OCLC is more efficient for cataloging than Aleph and the characters are larger and much easier to read, so they can proofread more easily (Seely, 2009). In 
summary, the procedure for cataloging library materials, monographs in particular, starts with determining if the material is in the library's union cataloging records. The second step is to access OCLC Connexion and create a batch file. In the Query Box, some access points including ISBN number, OCLC number, or LC number need to be entered. The third step is to process the batch in OCLC Connexion. The last step includes preparing bibliographic records for export to the local cataloging database.

Copy cataloging is preferred as a cost effective cataloging procedure. Outsourcing cataloging also brings some benefits to many U.S. libraries, since they can reduce costs and maintain the consistency of cataloging formats. For example, University $\mathrm{B}$ and $\mathrm{N}$ use their outsourced cataloging vendor for Japanese language materials from Kinokuniya. Some of the materials have been shipped from Japan, and they are shelf-ready. Outsourced cataloging agencies help reduce the staff member, mainly due to the budget cut. Outsourcing is also useful for handling materials in foreign languages, which tend to be challenging for many catalogers.

As Morris's study shows, Iowa State University Library catalogs more than 90 percent of all new monographic titles at receipt with a copy found in the OCLC database. Two major library automated systems used by many U.S. academic libraries include OCLC and RLIN (merged with OCLC in July 2006). Gregor and Mandel's study, "Cataloging Must Change!," urged catalogers to become more efficient and find ways to increase the completeness and currency of bibliographic access systems without spending more money. These two cataloging networks have been operating in the U.S. and have created significant numbers of bibliographic databases. Data from the Technical Services 
Division (TSD) of ISU shows that cataloging costs have dropped continually since 1991 and that cataloging is cost-effective in relation to other library functions (Morris and Wool, 1999). This has happened under conditions common to nearly all libraries in North America: the shift from card to online catalogs; the increasing automation of cataloging activities; decreasing staffing for cataloging; greater involvement of support staff in the creation of bibliographic data; and the growing presence of new information formats requiring new approaches (Morris and Wol, 1999). Machine translated texts are not suitable as they are, even though machine translation is helpful for the catalogers (Sugimoto; Lee; Zhao, et al, 2002). In fact, another key factor of this trend is seen in the growth in shared cataloging and authority records. Cataloging has even become shared internationally. In addition, in the 1990 article by Ann Allan, "Chasing MARC: Searching in Bibliofile, Dialog, OCLC, and RLIN" she compared hit rates in OCLC and RLIN by searching a sample of 1,000 English and foreign language monographs (Allan, 1990). The first search revealed that cataloging copy was found in OCLC for 86.3 percent of the titles and for 76.6 percent in RLIN. A year later, the percentages of matches increased to 91.2 percent in OCLC and to 85.9 percent in RLIN.

Seven university libraries surveyed replied that they take advantage of OCLC's ready-to-use bibliographic records. OCLC membership enables these libraries to create bibliographic records by using few staff and less professional catalogers. Therefore, outsourced cataloging and copy-cataloging are favored because of improving the efficiency of cataloging workflow in terms of cost effectiveness and time efficiency. 


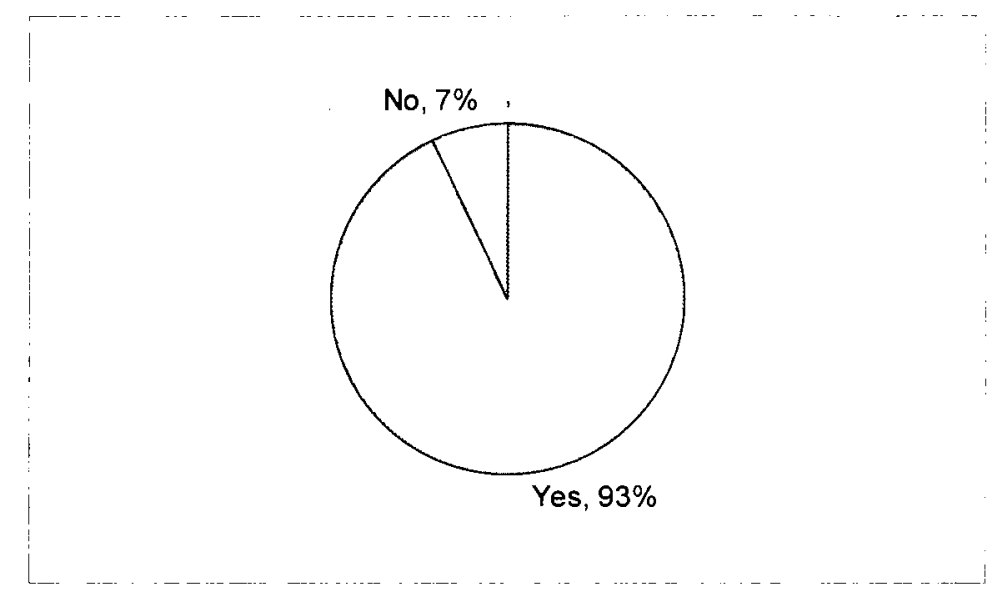

Figure 8. OCLC WorldCat as a copy-cataloging tool

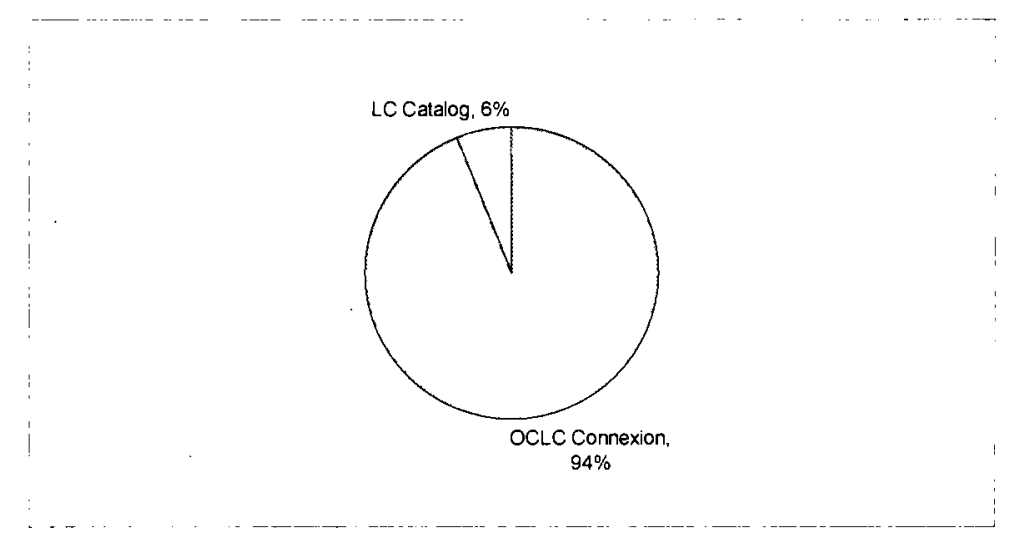

Figure 9. Use of national level bibliographic databases for searching titles

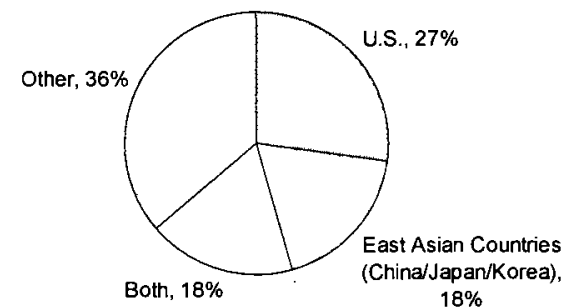

$18 \%$

Figure 10. Locations of outsourced cataloging vendors for CJK monographs 


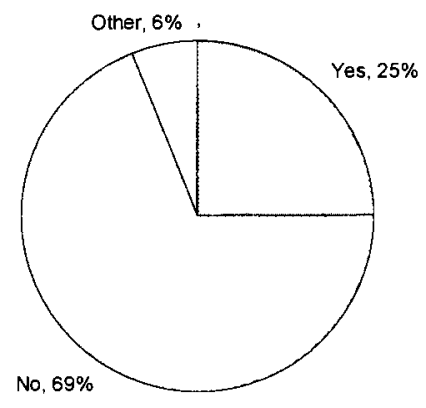

Figure 11. Shelf-ready service from outsourced cataloging vendors

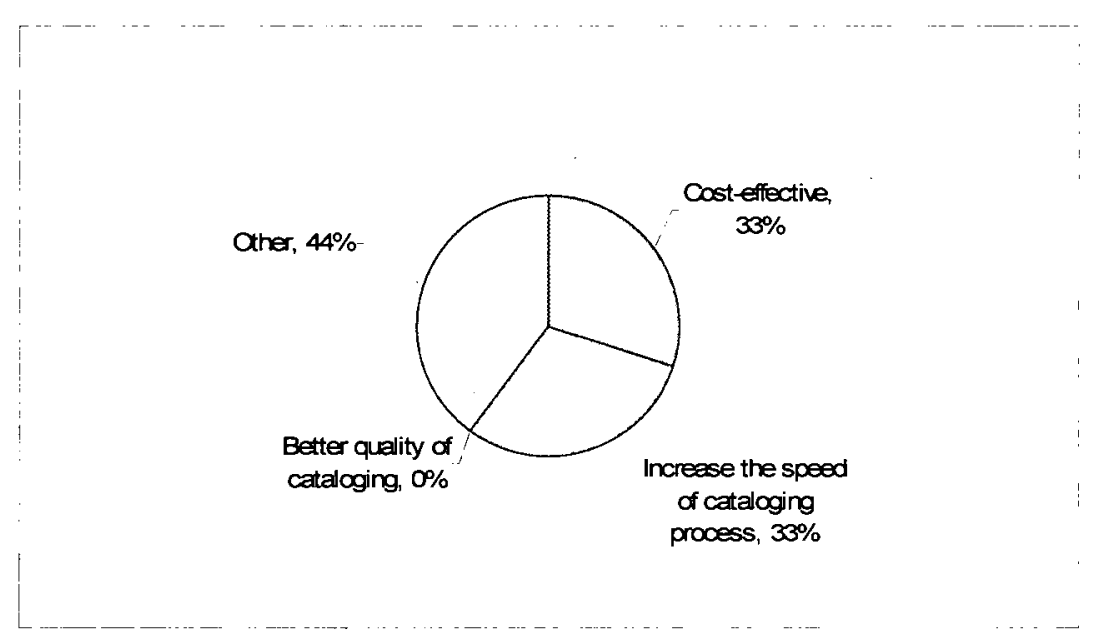

Figure 12. Benefits of outsourced cataloging

\section{Backlogged CJK Library Materials}

Through this study, the author has also found how backlogged CJK materials have been managed. The figure 13 shows the number of each type of CJK backlogged material held at thirteen university libraries as of June 2008. The partial statistics were based on CEAL (CEAL, 2009). Of these, no information was obtained from University E. University $\mathrm{K}$ and $\mathrm{M}$ had no backlog for each type of $\mathrm{CJK}$ library material. Chao and King of Harold B. Lee Library at Brigham Young University reported the backlog of 
CJK books had increased since 1999 due to the following two reasons. First, their Asian cataloger retired, and it took some time to choose a replacement. Leysen and Boydston's survey results from a fall 2003 shows that the number of catalogers in U.S academic libraries is predicted to drop significantly due to the aging and subsequent retirement of the cataloging workforce. More specifically, fully one-third of the 2000 ARL cataloging population will retire by 2010. At a 2003 American Library Association (ALA) Conference, Camden stated that "Over one half of Library of Congress [LC] catalogers are eligible for retirement; almost 80 percent of LC paraprofessionals are over 50 years of age. "Many library school students are also older and enter the profession as second careers or after working in libraries as paraprofessionals" (Lyesen and Boydston, 2005, p.250). Second, they changed their library systems, and this change caused some problems in the interface with RLIN that took some months to resolve. Thus, no cataloging of Asian books was made at all for about a year. Regular purchases and even donation of CJK materials continued despite this situation. The solution for solving this problem was to do copy-cataloging, especially for Korean books, since almost all bibliographic records for Korean books they had were found online. Then, for Japanese books, a full-time staff person to handle was hired and trained enough to work through the cataloging workflow. In addition, a student assistant trained and supervised by the Asian Cataloger could start inputting brief Romanized Author-Title records into their local cataloging system. Interestingly enough, library patrons could still access CJK books while they were waiting for full cataloging. These books were considered as an 
Asian In-process collection, and they were cataloged as soon as they were returned (Chao and King, 2004).

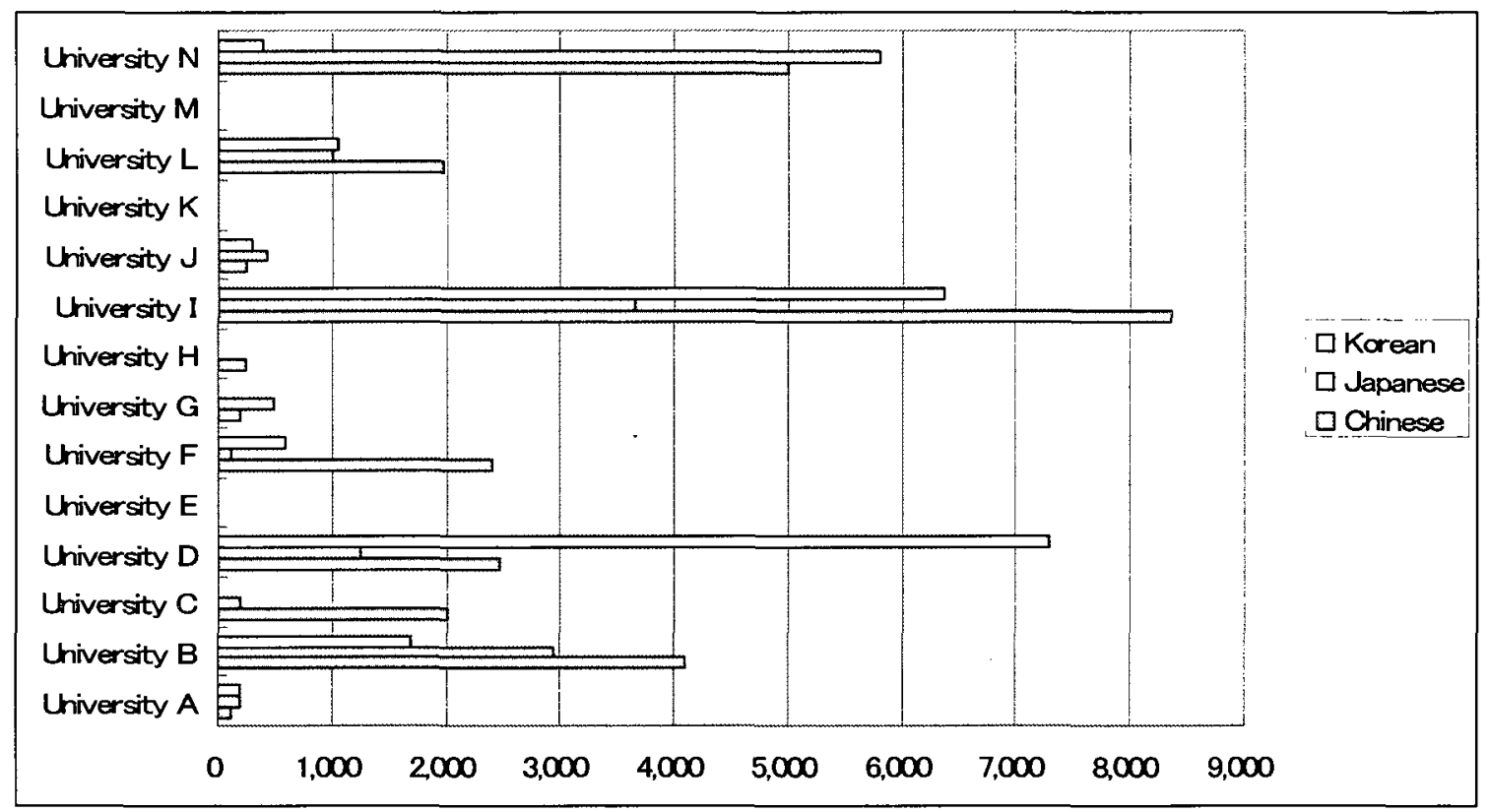

Figure 13. Number of backlogged CJK materials

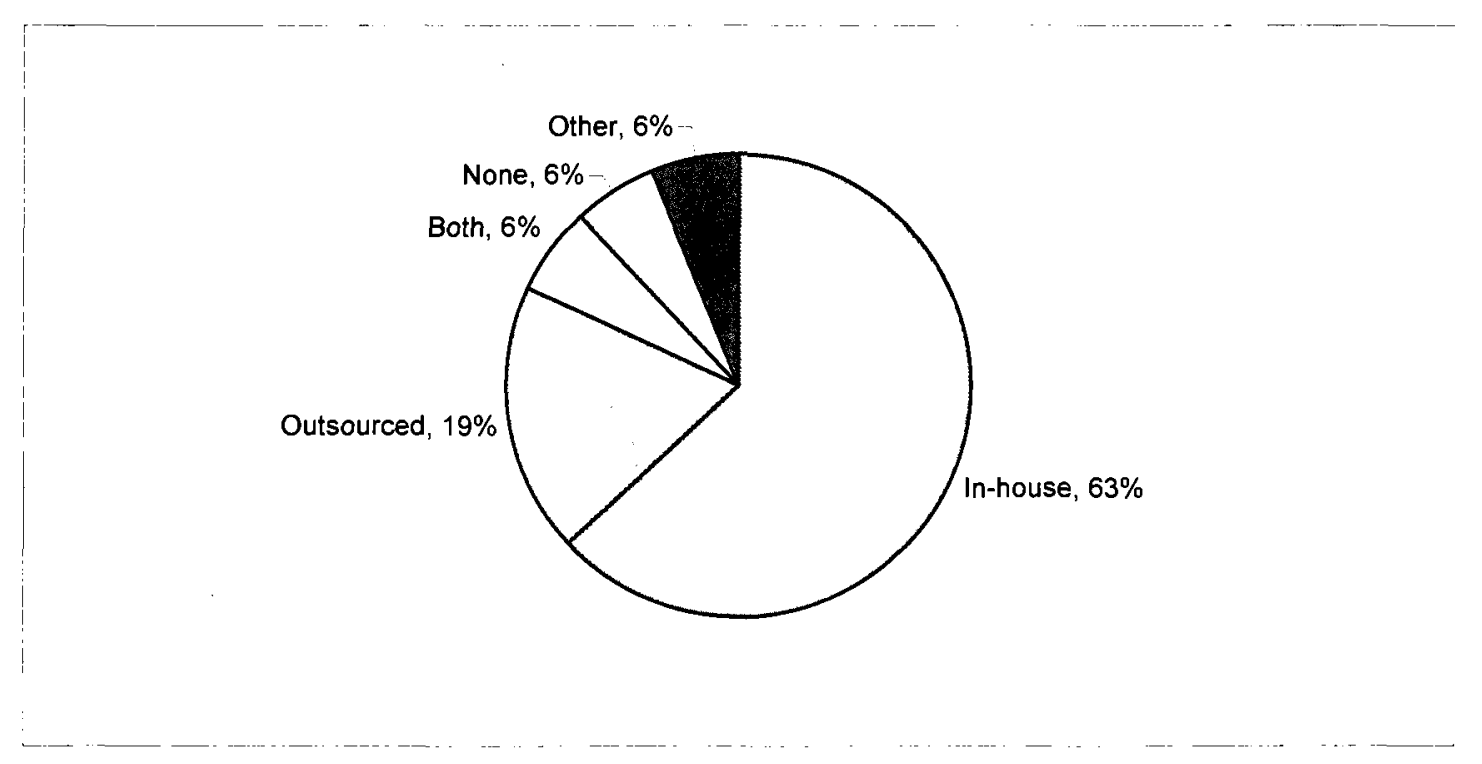

Figure 14. Management of backlogged CJK materials 


\section{Transition from RLIN to OCLC}

Some primary differences in MARC 21 fields used between OCLC and RLIN bibliographic records need to be noted here, as Elman of East Asia Library of Yale University has reported at the transition phase from RLIN to OCLC (Elman, 2007). Moreover, OCLC has provided some guidelines for RLIN21 users who are new to OCLC's Connexion client (Kopycki, 2007).

Although there are some similarities between these two, there are some major differences that require adjustment for new Connexion users. The major differences include: 1) Non-Latin parallel script fields appear before the Latin script field in Connexion, not after, as in RLIN21. 2) For non-Latin scripts without parallel fields, in RLIN21 users are required to enter $\$ 6$ before $\$ a$, but in Connexion, there is no need for entering \$6. 3) The display of the 066 field (Character Sets for non-Latin scripts Present) of Connexion is different from RLIN21. In Connexion, this field is automatically generated, and thus it should not be deleted. 4) For missing or invalid CJK MARC-8 characters, users of RLIN21 were asked to enter geta " $=$," but in Connexion, users are required to enter Romanization in brackets " $<>$." 5) For spacing, there's no space placed before and after subfield codes in RLIN, while the space is provided before and after subfield codes for OCLC records. 
Order of non-Latin script data:

Example of RLIN Record

\begin{tabular}{|l|l|l|}
\hline 245 & 00 & \$aShōwa kayō daizenshū. / \$cMurakami Ryū. \\
\hline 245 & 00 & \$a 昭和歌謡大全集 $/$ c 村上龍著. \\
\hline
\end{tabular}

Example of OCLC Record

\begin{tabular}{|l|l|l|l|}
\hline 245 & 0 & 0 & 昭和歌謡大全集 / \$c 村上龍著. \\
\hline 245 & 0 & 0 & Shōwa kayō daizenshū. / \$c Murakami Ryū. \\
\hline
\end{tabular}

Spacing between subfields:

Example of RLIN Record

\$aShōwa $\$ kayō $\oslash$ daizenshū. $/$ cMurakami Ryū.

$\$ a$ 昭和 歌謡 大全集 $/ \$ \mathrm{c}$ 村上 龍 著.

Example of OCLC Record

\begin{tabular}{|l|l|l|l|}
\hline 245 & 0 & 0 & 昭和歌謡大全集 / \$c 村上龍著. \\
\hline 245 & 0 & 0 & Shōwa kayō daizenshū. / \$c Murakami Ryū. \\
\hline
\end{tabular}

The following two case studies are catalogers who have transitioned from RLIN and OCLC Connexion, since they have faced a variety of issues with regard to the transition process from RLIN21 to OCLC Connexion. In the case of Cornell University 
Library, the library switched from RLIN to OCLC Connexion in October 2006, a few months after the formal announcement of the merger of OCLC and RLG was made. During the transition phase, the cataloging workflow was thoroughly reviewed. The switch from RLIN to OCLC changed their cataloging practices. A substantial number of books are processed in the "fastcat" method. They search for a fully cataloged record in OCLC/RLIN when a book arrives. In RLIN choosing a suitable record was one-stop shopping, while OCLC Connexion displays only the master records, so they have to search another database, WorldCat, to see other libraries' records. Some of the master records found in OCLC Connexion are not always the best to be chosen. For example, in the records of OCLC, there are some CJK master records displayed only in Roman, while one of the holding library's records includes CJK data instead. For this reason, the library expects OCLC to develop a program that replaces these simple records with fuller ones, and replace Roman only CJK records with ones that include CJK data (Mei, 2007, p.5-6).

In the cataloging practices managed at East Asia Library of Yale University, as of May 2006 (effective in July, 2006), when the announcement of the merger of OCLC and RLG was made, some CJK cataloging staff members started to experiment with using OCLC Connexion. Four months later, all NACO contributors at Yale University were trained to use Connexion for creating and updating authority records. In December 2006, all non-Roman cataloging staff were given some training for general OCLC Connexion by the outsourced cataloging agency, NELINET, a company that supports library and information resources mainly for the six New England states. In OCLC Connextion, the 
identification of institutions that created the original bibliographic records is easily located by field 040. CJK E-Dictionary is a useful feature to convert non-MARC-8 records as well. On the other hand, there are some features that need to be improved. For example, many bibliographic records obtained from OCLC Connexion lack call numbers, since some institutions use field 090 instead of field 050 for call numbers. In addition, many bibliographic records have non-LC subject headings.

A cataloger from University D comments in the survey that there were three major challenges they faced at the time of transition from RLIN to OCLC. First, the East Asian Library's holdings have not been totally reflected in OCLC WorldCat due to the setup of record upload profile. Second, some catalogers had difficulty adjusting to the Master Record principle of OCLC. Third, uneven quality of Master Records which need to be enhanced.

\section{Maintenance and Update Bibliographic Records}

Another finding from this survey was the cost related issue. Maintenance and update of bibliographic records is often ignored in the daily workflow. It seems to be thought of as a secondary cataloging practice that tends to be taken care of once the records are in place. One cataloger who responded to the survey pointed out that due to the budget shortages and lack of funding, they are not able to maintain and update their bibliographic database, while another library mentions that every month they send bibliographic records to Marchive where they check or update their records. Backstage and Library Technologies, Inc. are other vendors doing cataloging maintenance including authority file clean up service. Marchive Inc., headquartered in Texas, offers various 
library cataloging processes, including providing MARC bibliographic records and authority processing. Though different authority control vendors offer different menus of services, nearly all provide four basic services: automatic MARC update processing, automatic batch authority control processing, manual review, and current cataloging service. These vendors use "the current MARC 21 standard to validate and update numeric field formats, to update fixed fields, and to update or delete tags and subfield codes" (Zhu and Seggern, 2005, p.50-51).

In addition, the acquisition department occasionally has to create bibliographic records to place orders when there is no copy, including no vendor copy, available. Similarly, student assistants have created records for older materials without copy before sending them on to their original cataloger. Since both the Acquisition department and the cataloging services are in the same division, they are often able to interact with each other, especially for the cataloging workflows. After the Collection department orders the materials, the Acquisition department brings a record from OCLC and creates an order record. The Acquisition department acquires the materials when they are delivered to the library. The Cataloging department then checks the records to see whether each one is correctly split, and then they start processing to create the bibliographic records for each material. More specifically, since Cataloging Service Bulletin No. 57 (LC, 1992) gives guidelines for how to determine library materials cataloged as CJK, a new record needs to be input if the language is a JACKPHY (Japanese, Arabic, Chinese, Korean, Persian, Hebrew, and Yiddish) language and at least two of the following are in nonRoman script regardless of the language of the script: field 245 (Title and statement of 
responsibility), 250 (Edition), 260 (Publication, Distribution, etc.), and 4xx (Series statements) (Cataloging Service Bulletin, No. 57, Summer 1992).

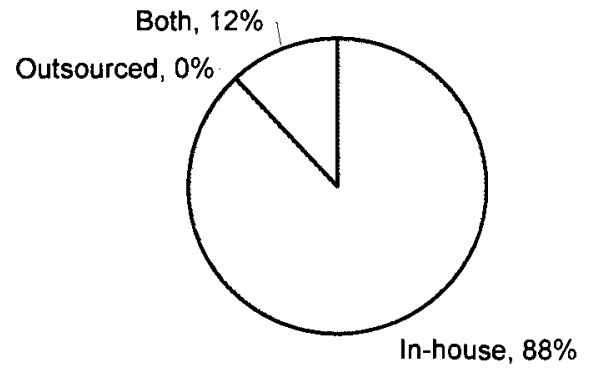

Figure 15. Update and maintenance of bibliographic records

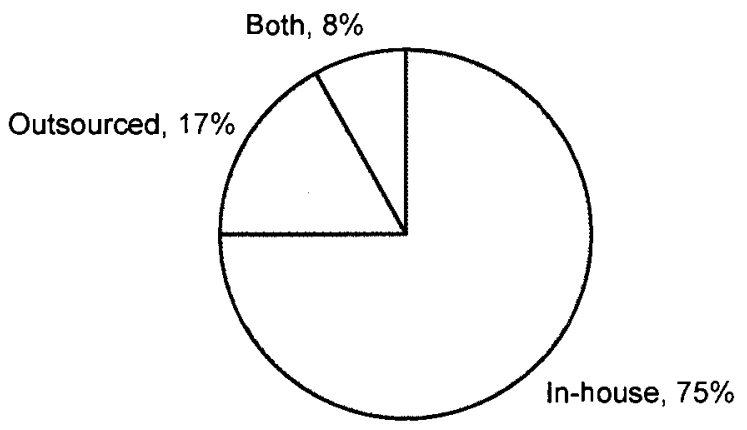

Figure 16. Update and maintenance of authority records

\section{Language Competency for Catalogers}

With regard to training, the survey shows that language competency for cataloging librarians is often required, and some of them have taken languages courses prior to entering their professions. In other words, multilingual skills are needed for 
constructing bibliographic records in various languages. There are several important tasks that catalogers are required to use languages other than English as part of their daily routine workflows. Besides language skills, an understanding of the associated cultural environment is an important component of cataloging in other languages. This includes history, geography and politics as well as some knowledge of publishing traditions (Jilovsky and Cunningham, 2005). Current automated cataloging software such as OCLC Connexion certainly helps make cataloging procedures more effective, but there are still some cataloging practices that required native-level language skills.

"Transliteration, for example, is cumbersome and time consuming for the cataloging staff and is difficult and in some cases impenetrable to the native speaker" (Haddad, 2003, p.487). Although linguistic abilities are frequently listed among cultural competencies, library schools do not have any language requirement nor do they offer special training for language-related librarian positions or copious language-related tasks in a library for public or technical services. At the same time, "in the case of many languages, collaboration among all departments, such as vendor, acquisitions staff, cataloging staff, and selector has resulted in significantly lower turnaround times and fewer mistakes" (Ward, 2009, p.92).

Hall-Ellis' study shows that employers and technical services managers recognize the importance of hiring catalogers who possess reading and writing proficiencies in multiple languages. "The identification of catalogers who bring language proficiencies with them is essential for maximizing access to multilingual resources available locally and globally" (Hall-Ellis, 2007, p.31). Unfortunately, Library and Information Science 
(LIS) programs in the U.S. do not include specific references to languages and multilingual proficiencies in terms of reading, writing, and translating.

The following figure, language proficiencies reported in Hall-Ellis' case study, indicates of twenty-two different languages, the library employees most frequently list Spanish, French, and German, while they list East Asian CJK languages less frequently.

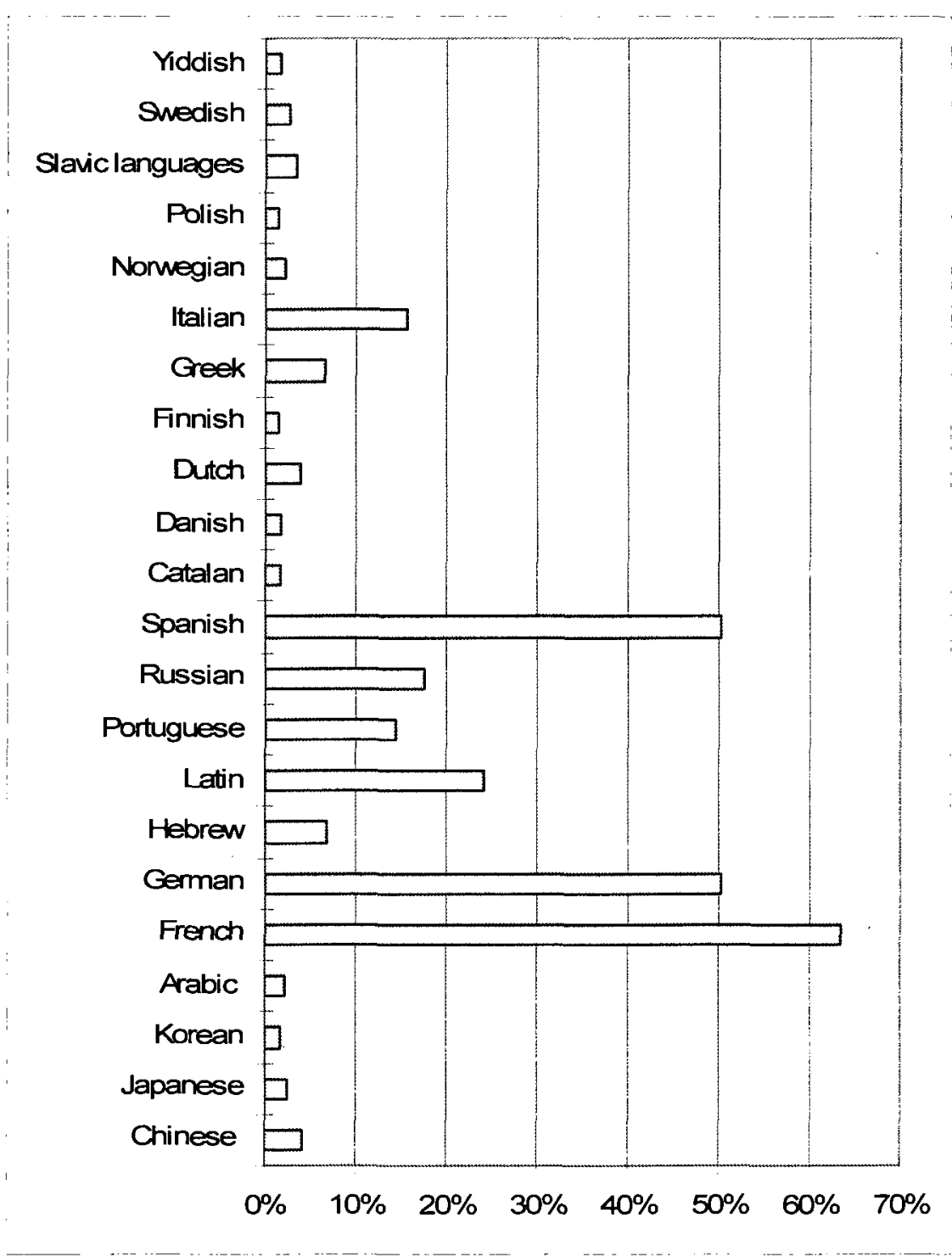

Figure 17. Lists of top 22 language proficiencies for librarians 
The proficiency of CJK languages used for the cataloging activities is focused in this study. As shown in the figures below, there are five different scales used to measure how the language skills including reading, writing, and speaking the CJK catalogers have. More than half of the survey respondents identified themselves as native or bilingual in their specialized CJK languages. Neither of Chinese and Japanese specialized catalogers is elementary nor limited working proficiency. On the other hand, the language proficiency in Korean seems to be a little less specialized among the catalogers, since a couple of respondents mentioned that the Japanese copy catalogers also catalog the Korean library materials.

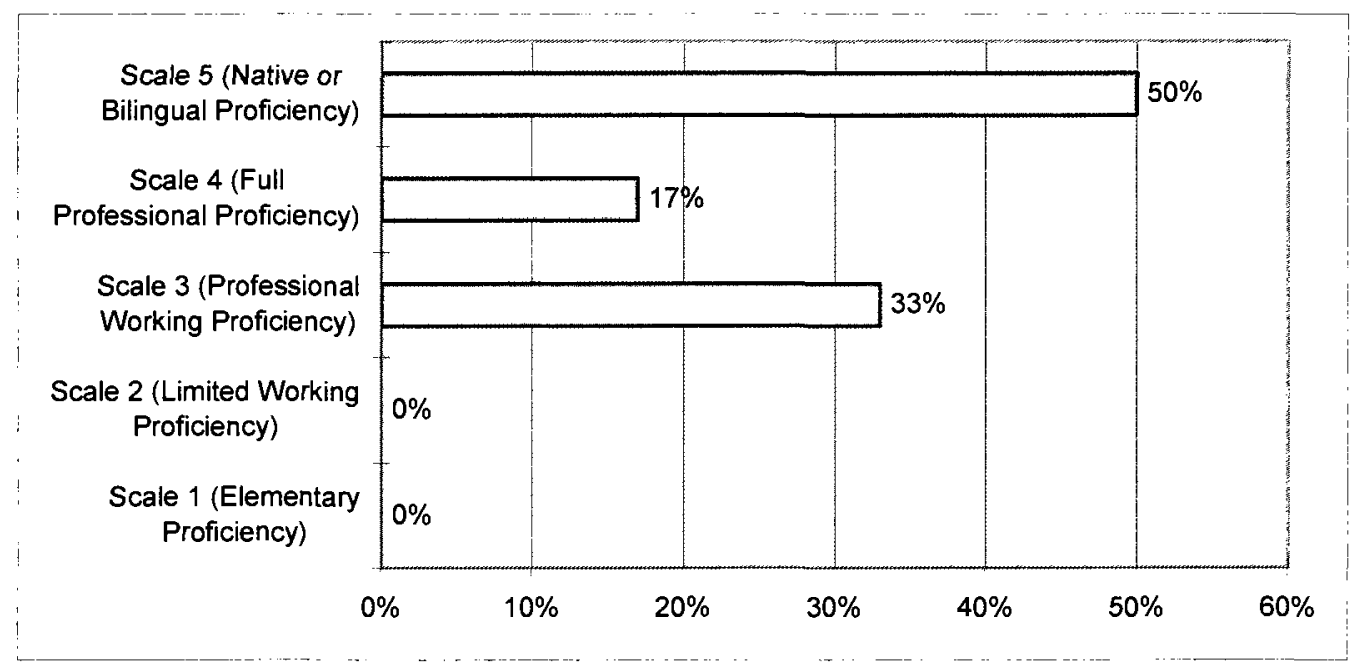

Figure 18. Language proficiency level (reading/writing/speaking) in Chinese 


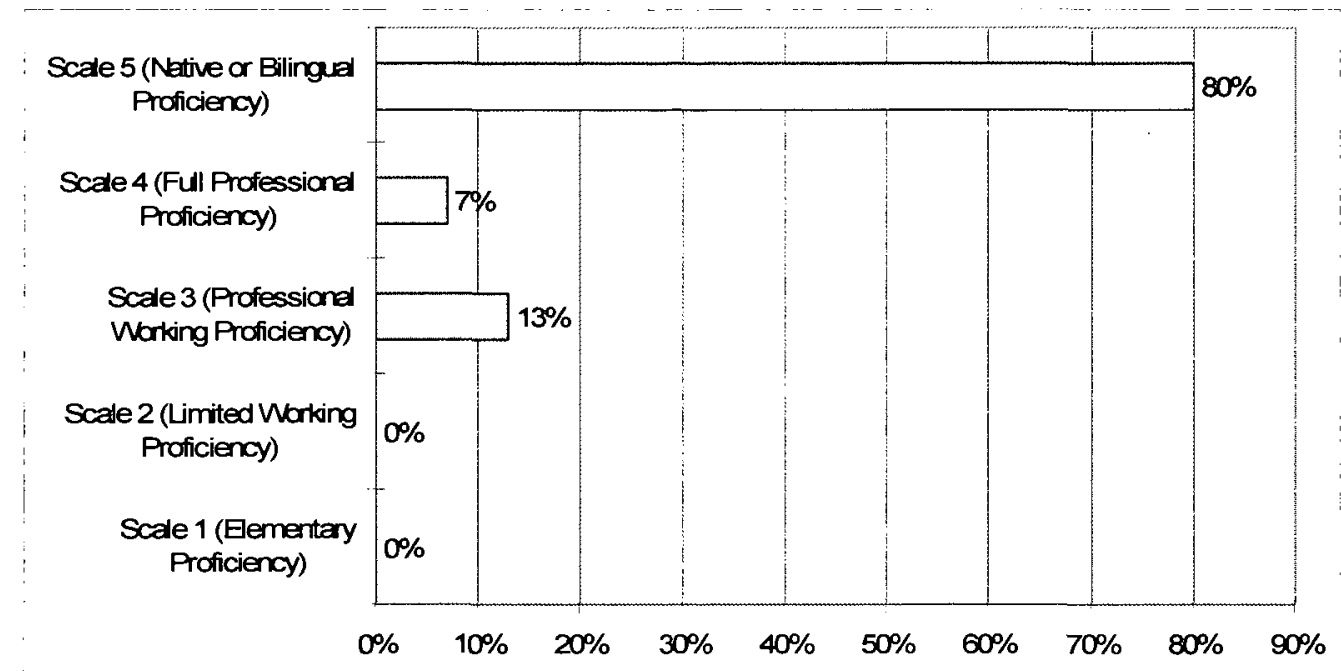

Figure 19. Language proficiency level (reading/writing/speaking) in Japanese

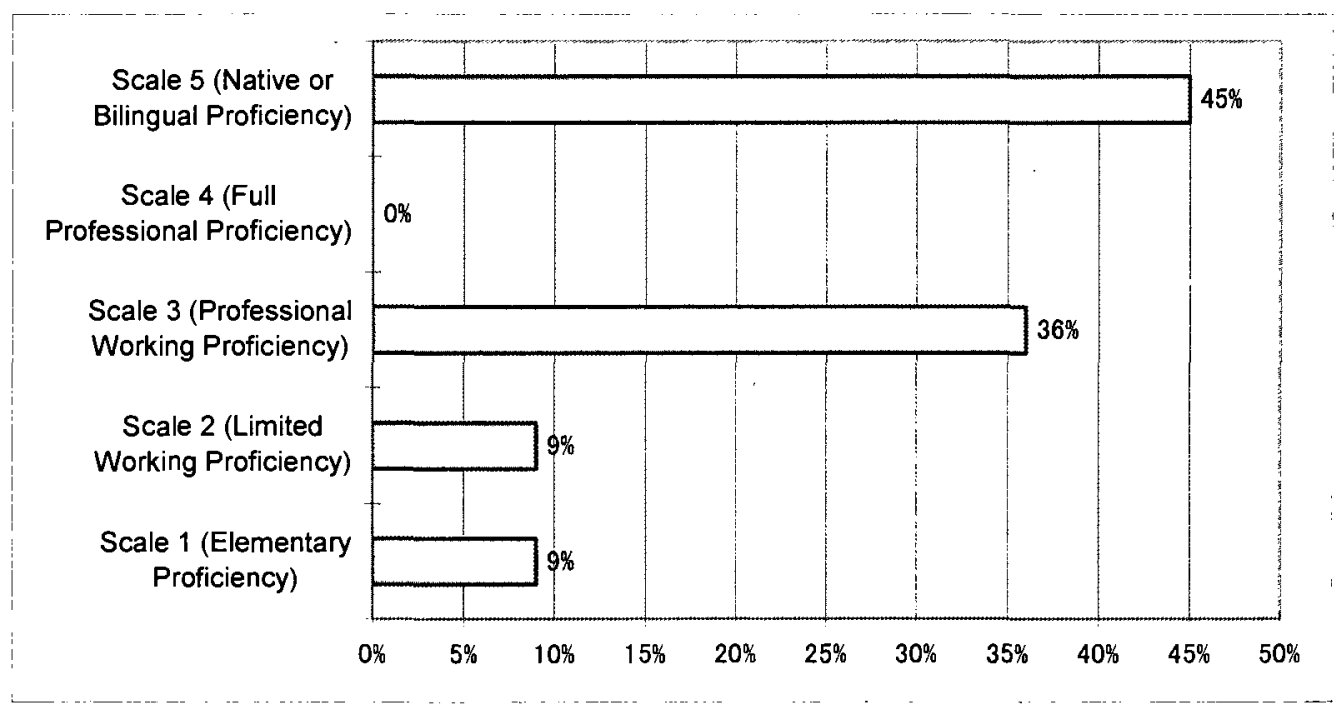

Figure 20. Language proficiency level (reading/writing/speaking) in Korean 
The last statistics give us an idea of what specific areas of cataloging practices are used for the cataloging workflow. A majority of respondents in the survey reported that the identification of bibliographic elements and the determination of main topics for creating subject headings are their two primary cataloging activities.

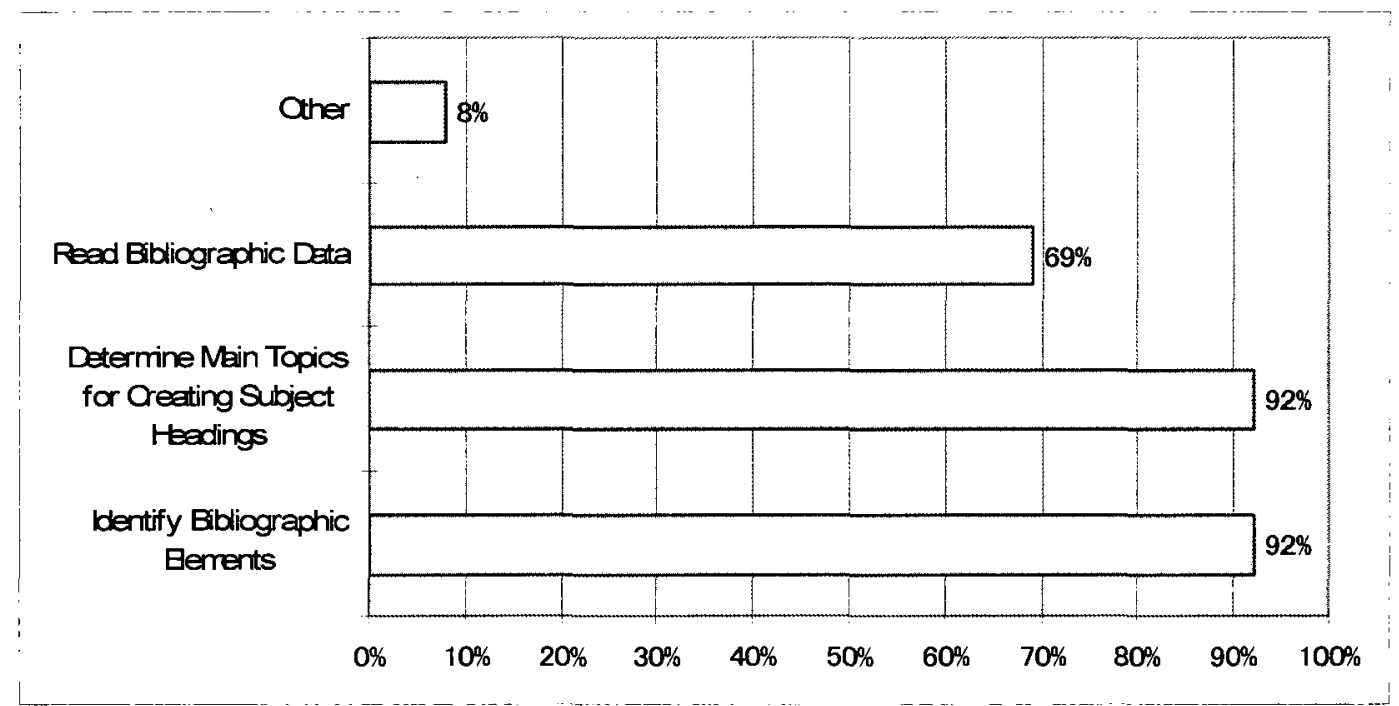

Figure 21. Lists of cataloging activities for CJK library materials

Cataloger's tasks of creating precise and accurate CJK library cataloging records are still challenging, especially because of varying proficiencies with CJK languages. Most library schools have not required students to have language competency in the course curriculum. However, in the near future multilingual competencies in cataloging as well as some other library science fields need to be reconsidered.

\section{Changes in Cataloging Practices}

Lastly, the catalogers have been through several changes in their workflow, as they commented in the survey to the question: what changes are coming to cataloging and 
how will the cataloging department meet them? Those catalogers who responded to this survey think that there are some possible changes to format and philosophy, and ongoing changes to technology, both in the functions of their Integrated Library System (ILS) and in what it can make available to users. At the same time, they seem to be very openminded to the changes, as they work on outsourcing projects as well as the current transition plan from AACR2 to RDA. For RDA, some of them have attended the session on the topic. 53 percent of survey respondents have attended some sorts of cataloging training for the RDA. When it is implemented, they will seek training from OCLC to better understand and implement RDA. At the same time, they are currently watching the processes of RDA, Functional Requirements for Bibliographic Records (FRBR), and Functional Requirements and Numbering of Authority Records (FRANAR), but waiting to see how implementation and training will impact them at a later date. They encourage staff to attend local training, some put on by OCLC, and some by local groups, Northern California Technical Processes Group (NCTPG), for instance. They do this because they look for more collaboration or new approaches to reduce redundant work and improve efficiency. Many of them mentioned that they are experiencing staff shortages and have to adjust their workflow and reassign their job duties to meet the challenge. The other big challenge that they foresee coming to cataloging is the diminishing of staff. For example, one cataloger from the California State University system said that when she started working there were five full time MLS catalogers. Now there is only she. She has been told that the two part-time catalogers will not be replaced by other MLS catalogers. Additionally, most of the rest of the cataloging staff members have been at this library for 
twenty to thirty years. Within five to eight years, she expects that most of them will retire (Moore, 2008). They also commented that they are currently facing decreased manpower and increased variety of materials to handle. They try to provide more training for staff members as new materials are coming and cataloging rules are being changed. As for the budget issues, more and more the library administration has to look for ways of money saving and ignore the quality of cataloging. The cataloging department in the academic libraries is greatly shrinking, if not disappearing. So is the professional cataloging staff. The library administrator (non-professional cataloger or even not a cataloger) always has the final say about and frequently interfered with the cataloging business and consequently caused the quality of cataloging hopelessly sliding downward. Quality of cataloging is no longer important these days.

Furthermore, the other big change they have faced lately is an increase of Electronic Book (E-Book) formats, and the move to a Google-like search, such as LibraryThing and Aquabrowser, from traditional OPAC. E-Books will be purchased at an increasing speed and their cataloging librarians and para-professional catalogers will be trained how to catalog these new types of books. It is also true that these catalogers have spent much less time on cataloging, and some of them are shifting to electronic resource cataloging. Therefore, cataloging department needs to change accordingly. 


\section{Conclusions}

Libraries have made the transition from the old card cataloging system to automated online cataloging systems over the last two decades. OCLC's agreement about retrospective conversion from traditional catalog cards to machine-readable form with some large East Asian libraries is a good example. The agreement was made between OCLC, Cornell University, the University of Pittsburgh, and the Chinese University of Hong Kong. A total of 209,000 CJK titles were planned to be converted between late 1995 and June 1997 (OCLC, Nov 1995). That was ten years after the online CJK shared cataloging system was launched. Of these changes, the creation and the transliteration of CJK vernacular scripts have helped improve information retrieval among many U.S. CJK library communities. With the application of this new transliterated system, authority control including the name authority file for author's name, geographic names, and corporate names, becomes a more essential component for information retrieval. The advancement of new technologies have been incorporated into the CJK library cataloging system these days, but inconsistency in cataloging rules especially due to the intricate mechanism of CJK languages with English-based cataloging system, seems to arisen in many areas in advanced online cataloging system. Therefore, consistency in cataloging rules is an important fundamental principle of information retrieval for library users. It is true that catalogers' tasks require more time to complete as the amount of information and the size of metadata grows, but understanding the cataloging rules and having high language proficiency help to improve the quality of library catalogs. Since no further analysis of what exact types of CJK 
cataloging practices cause more complexity in cataloging Japanese monographs has been made so far, this study hopes to make it clear how the current cataloging rules for authority control and the cataloging practices for the CJK monographs can assist catalogers and users to improve their search retrieval. Without any rigid authority control as well as consistency in the form of names, titles, and subject headings for CJK bibliographic records, there will be no efficient access to information in a library catalog. More active participation of international leveled cooperative cataloging is expected especially for those authority records for CJK names. The cooperative cataloging program at the international level is beneficial, especially because maintaining and creating the existing authority records for Japanese names by those who have long-term experience with the language and culture seems to be more reliable and valuable. In other words, the nature of language is very culturally oriented, and tends to keep changing as the time goes on. This way, cataloging will be more productive and functional, as CJK catalogers working for the U.S. libraries can spend their time more wisely. 


\section{Future Issues and Recommendations}

Currently the Subject Authority File, which is controlled by the LC, is limited to only Latin script, since not all contributors have systems with non-Roman script searching capabilities. In the future any script could be used in authority records. Multiple authority files can be linked together to provide multilingual and multi-script access. Virtual International Authority File (VIAF), a joint project with LC, Deutsche Nationalbibliothek, the Bibliothèque nationale de France, and OCLC, needs to be enhanced for CJK authority files. "To provide equal and effective access, a library with a multi-script collection for readers of different scripts needs a multi-script catalog based on cataloging rules that specify access in the original script" (Agenbroad, 2006, p.30). Moreover, a cooperative cataloging program network between the U.S. and East Asian countries has still not been fully established, although a bibliographic contribution has been made by a few large university libraries and cataloging vendors. Based on the findings discussed in this study, the following conclusions are drawn. Training guidelines and manuals need to be written in CJK languages, to help those international participants of the PCC program have a better understanding of the cataloging rules of AACR2 and LCRI. As in Tillett's study, "authority files could be shared among all library communities in the world, since shared authority information has the added benefit of reducing the global costs of doing authority work while enabling controlled access and better precision of searching" (Tillet, 2002, p.2). "Linking and mapping in different ways within and between systems and between authority files of different kinds is seen as the main route towards global access" (Johnson, 2006, p.52). By taking 
advantage of the technology available for the library communities, a system of controlling access points can manage both local authority files and international ones. Currently, with the recent contribution of this workbook by many CEAL members and LC employees, the descriptive cataloging rules (AACR2 and LCRI) of East Asian material are available online in pdf files, but not all chapters have been posted yet. In the near future, the remaining chapters will be ready, and it is also expected to develop into more comprehensive guidelines available for CJK catalogers. For example, the Library of Congress's Cataloger's Desktop for CJK materials could be a good source of the CJK cataloging reference. Since library schools do not have any language requirement nor do they offer special training for language-related librarian positions or copious languagerelated tasks, the curriculum of the library science classes needs to be improved in the near future. More importantly, in order for catalogers and non-native speakers from outside the U.S. to interpret and access these guidelines easily, the maintenance and the creation of bibliographic files need to be done internationally. 


\section{References}

Agenbroad, J. E. (2006). Romanization Is Not Enough. Cataloging \& Classification Quarterly, 42(2), 21-34.

Aliprand, J. M. (1993). Special section: A Decade of East Asian Scripts on RLIN. Information Technology \& Libraries, 12(4), 423-426.

Aliprand, J. M. (2005). Scripts, Languages, and Authority Control. Library Resources \& Technical Services, 49(4), 243-249.

Aliprand, J. M. (2005). The Structure and Content of MARC 21 Records in the Unicode Environment. Information Technology and Libraries, 24(4), 170-179.

Allan, A. (1990). Chasing MARC: Searching in Bibliofile, Dialog, OCLC, and RLIN. Journal of Academic Librarianship, 15(6), 339-343.

Aman, M. M. (1980). Cataloging and Classification of Non-Western Material: Concerns, Issues, and Practices. Phoenix: Oryx Press.

American Library Association. (2005). Anglo-American Cataloging Rules Second Edition (AACR2). Chicago: American Library Association.

American Library Association. (2008). Minutes of the CC-AAM Meeting at ALA Midwinter 2008. Retrieved from http://www.atyourlibrary.org/ala/mgrps/divs/alcts/mgrps/ccs/cmtes/catalogingasia na/mw08ccaam_min.doc

American Library Association. (2006). ALCTS Task Force on Non-English Access, Comments Received and Their Disposition. Retrieved from http://www.ala.org/ala/mgrps/divs/alcts/ianda/nonenglish/07rptcomments.pdf

Asakura, S. (2004). Nihongo MARC no XML Database e no henkan ni kansuru ichi jikken, JAPAN/MARC to TRC MARC no henkan [An Experiment on Conversion of Japanese MARC to XML Database, JAPAN/MARC and TRC MARC]. Nihon Toshokan Johō Gakkai-shi [Annals of Japan Society of Library Science]. 50(4), 159-170.

Borbinha, J., Kaiser, M., \& Ottosson, P. (2003). Model Application Requirements Document, LEAF-Linking and Exploring Authority Files. Retrieved from http://www.crxnet.com/leaf/docs/MARD_V1.0.doc 
Bolick, H. (2004). When Parallels Collide: Parallel Records, Parallel Fields and Hybrid Records. OCLC Users Group Annual Meeting. Retrieved from http://oclccjk.lib.uci.edu/oclccjk04/parallels.ppt

Buizza, P. (2004). Bibliographic Control and Authority Control from Paris Principles to the Present. Cataloging \& Classification Quarterly, 38(3), 117-133.

Bunparit, N. (1998ca.). Cataloging in Japanese Libraries. Retrieved from http://library.rsu.ac.th/pdf/j8chapter\%205.pdf

Burger, R. H. (1985): Authority Work: the Creation, Use, Maintenance, and Evaluation of Authority Records and Files. Colorado: Libraries Unlimited.

Byrum Jr. \& John D. (2004). NACO: A Cooperative Model for Building and Maintaining a Shared Name Authority Database. Cataloging \& Classification Quarterly, 38(3), 237-249.

Camden, B. P. (2007). Task Force on Non-English Access, Report. Association for Library Collections and Technical Services. Retrieved from http://www.ala.org/ala/mgrps/divs/alcts/ianda/nonenglish/07marchrpt.pdf

Carpenter, M. (1988). National and International Bibliographic Databases: Trends and Prospects. New York: Haworth Press.

Chang, M. (1998). OCLC in Asia Pacific. Journal of Library Administration, 25(2), $129-$ 140.

Chao, E. \& King, G. (2004). Bringing a Backlog Under Control: How We Did It at BYU. Journal of East Asian Libraries, 134, 26-28.

Connell, T. H. (1991). Librarian Subject Searching in Online Catalogs: An Exploratory Study of Knowledge Used (Doctoral dissertation). University of Illinois at Urbana-Champaign, Illinois.

Council on East Asian Libraries (CEAL) Statistics Committee. (2009). Council on East Asian Libraries Statistics 2007-2008 for North American Institutions, 2008 [Data file]. Retrieve from http://lib.ku.edu/ceal/stat/20072008/cealstat2007_08.pdf

Creswell, J. W. (2008). Research Design: Qualitative, Quantitative, and Mixed Methods Approaches. California: Sage Publications.

Denda, K. (2005). Beyond Subject Headings. Library Resources \& Technical Services, 49(4), 266-275. 
Donovan, M. \& Tosaka, Y. (2005). Report on the Information Needs Assessment of the Japanese Collections at the Ohio State University. Retrieved from https://kb.osu.edu/dspace/bitstream/1811/6180/1/Report\%20on\%20the\%20Inform ation $\% 20$ Needs\%20Assessment $\% 20$ of $\% 20$ the $\% 20 \mathrm{Japanese} \% 20$ Collections.pdf

Ellett, R. (2005). An Evaluation of Program for Cooperative Cataloging (PCC) Records Used in Non-PCC Libraries (Doctoral dissertation). Nova Southeastern University, Florida.

Falk, J. D. (1989). OCLC and RLIN: Research Libraries at the Scholar's Fingertips. American Historical Association, May-June 1989. Perspectives. Retrieved from http://www.historians.org/perspectives/issues/1989/8905/8905NOTE.cfm

Fowler, F. J. (2008). Survey Research Methods. California: Sage Publications.

Gakujutsu Jōhō Center. (1999). Mokuroku Jōhō no Kijun [Cataloging Standard]. Tokyo: Gakujutsu Jōhō Center.

Garrity, W. (1995). Z39.50 at the Penn Library. PennPrintOut, 122.

Haddad, P. (2003). Cataloging and Classification of Pacific and Asian Language Materials at the National Library of Australia. Cataloging \& Classification Quarterly, 35(3), 483-489.

Haddouti, H. (1999). Survey: Multilingual Text Retrieval and Access. UNESCO Press. Retrieved from http://webplaza.pt.lu/craynaud/CLIR/SurveyMultilingualTextRetrievalandAccess.pdf

Hall-Ellis, S. D. (2005). Descriptive Impressions of Entry-Level Cataloger Positions as Reflected in American Libraries, AutoCAT, and the Colorado State Library Jobline, 2000-2003. Cataloging \& Classification Quarterly, 40(2), 33-72.

Hall-Ellis, S. D. (2007). Language Proficiencies Among Catalogers and Technical Services Librarians. Technical Services Quarterly, 25(2), 31-47.

Hanks, N. S. (2003). Authorities Out Of Control: Why Authority Control is Needed. Maryland Library Association 2003. Retrieved from http://www.loyola.edu/library/cat/Conf/AuthControl.ppt

Harai, N. (2007). Japanese Scripts and UNIMARC. International Cataloging and Bibliographic Control, 36(3), 55-58. 
Har-Nicolescu, S. (1987). Romanized and Transliterated Databases of Asian-Language Materials: History, Problems, and Prospects. Automated Systems for Access to Multilingual and Multiscript Library Materials, 13-33.

Helliwell, D. (2006). East Asian Cataloging in British Libraries: the Contribution of Allegro. Catalog \& Index, 153, 4-6.

Hickey, D. D. (2006). Area Studies Libraries in the Global Studies Milieu: Implications for Non-Roman Script Print Resource Management and University Library Budgets and Staffing. Library Collections, Acquisitions, and Technical Services, $30,77-84$.

Holley, R. P. (1993). Cooperative Cataloging Outside North America: Status Report 1993. Cataloging \& Classification Quarterly, 17(3/4), 201-236.

Hotelling, K. (1994). A Study of Japanese Vendor Services in North America. BulletinAssociation for Asian Studies, Committee on East Asian Libraries, 102, 1-8.

Hu, J. (2000). The Impact of Productivity and Quality of CJK Cataloging--A Brief Comparison Between CJK 2nd Edition and 3rd Edition. Cataloging \& Classification Quarterly, 29(4), 87-90.

Hu, L., Tam, O., \& Lo, P. (2004). Chinese Name Authority Control in Asia: An Overview. Cataloging \& Classification Quarterly, 39(1\&2), 465-488.

Hu, L. (1990). Online Cataloguing Systems for Chinese, Japanese and Korean Collections: An Evaluation Report from the University of Melbourne. LASIE (Library Automated Systems Information Exchange), 20(4), 70-79.

Irie, S. < irie@lib.keio.ac.jp> (2009, October 23 and 28). Re: Arigatō gozaimashita [Thank you] and Re: MARC tag hyōji ni tsuite goshitsumon [Question about the display of MARC tags] [personal emails].

Johnson, G. (2006). Cataloging and Subject Tools for Global Access: International Partnerships. International Cataloguing and Bibliographic Control, 35(3), 52-58.

Jilovsky, C. \& Cunningham, A. (2005). Multilingual Cataloguing: Practical and Technical Issues. Retrieved from www.iflastockholm2005.se/pdf/postconfdoc\%20IFLAswe05\%20pdf/Stockholm\%20presen tation.pdf

Kim, S. H. (1984). Authority control for East Asian Name Headings in Libraries with East Asian Collections a Survey of Practices and Expectations (Doctoral dissertation). University of Pittsburgh, Pittsburgh. 
Kokabi, M. (1995). The Internationalization of MARC: Part IV: UNIMARC, Some Formats Based on it and Some Other MARC Formats. Library Review. 44(7), 833.

Kokuritsu Kokkai Toshokan Shoshi-bu [Cataloging Department of National Diet Library]. (2003). Dai yon-kai Shoshi Chōsei Renraku Kaigi Kiroku-shū, Meisho Tenkyo no Control 2003 [Name Authority Control, the $4^{\text {th }}$ Conference on Bibliographic Control 2003], Tokyo: National Diet Library of Japan.

Kopycki, W. (2007). Using OCLC's Connexion Client, A Guide for RLIN 21 Users. Retrieved fromhttp://www.oclc.org/Support/documentation/connexion/client/cataloging/rlint ransitiontoclient.pdf

Kotaka, H. (2001). Waseda University Information Network (WINE) MARC Project, The Phase II Batchload Operation, WINE MARC Record Editing Guide (2001 version). Retrieved from http://lists.unc.edu/read/attachment/292627/2/WINE+MARC+PHASE+II+Editing + Guide.doc

Kotaka, H. (2003). Technical Bulletin 250: Parallel Records - Now Available. Message posted to E-mail List Subscriptions and Archive, archived at http://listserv.oclc.org/scripts/wa.exe?A2=ind0310\&L=oclc$\mathrm{cjk} \& \mathrm{~T}=0 \& \mathrm{~F}=\mathrm{P} \& \mathrm{P}=1860$

Kotaka, H. (2008). On revised WINE MARC records Batchload Procedure. Message posted to E-mail List Subscriptions and Archive, archived at http://listserv.oclc.org/scripts/wa.exe?A2=ind0802b\&L=oclc$c j k \& \mathrm{~T}=0 \& \mathrm{~F}=\mathrm{P} \& \mathrm{P}=75$

Kuo, E. (2007). Cataloging Outsourcing: Berkeley's East Asian Library's Experience. Retrieved from http://oclccjk.lib.uci.edu/oclccjk07/070CLC-CJK-UG-Kuo.ppt

Lam, K. (2002). XML and Global Name Access Control. OCLC Systems \& Services, $18(2), 88-96$.

Lee, T. \& Ohta, B. C. (1983). AACR2 Workbook for East Asian Publications. Madison: University of Wisconsin-Madison Libraries.

Library of Congress. (2008). 670 (Source Data Found) Citations for Name Authority Records with Non-Latin Script Data. Cataloging and Acquisitions Homes. Retrieved from http://www.loc.gov/catdir/cpso/non-Latin670.pdf 
Library of Congress. (1992). Cataloging Service Bulletin, 57. Retrieved from http://www.loc.gov/cds/PDFdownloads/csb/CSB_057.pdf

Library of Congress. (2008). CJK NACO Project, PCC. Cataloging and Acquisitions Homes. Retrieved from http://www.loc.gov/catdir/pcc/naco/CJK.html

Library of Congress. (2008). Guidelines for CJK NACO Review Process and Independence CJK NACO Project. Retrieved from http://www.loc.gov/catdir/pcc/naco/CJK/CJKReviewGuide.html

Library of Congress (2005). Highlights of Fiscal Year 2004, Part II, LC Cataloging Newsline. Online Newsletter of Bibliographic Access, 13(3), 1-8. Retrieved from http://www.loc.gov/catdir/lccn/lccn1303.pdf

Library of Congress. (1997). Japanese ALA-LC Romanization Tables. Cataloging and Acquisitions Homes, 73-85. Retrieved from http://www.loc.gov/catdir/cpso/romanization/japanese.pdf

Library of Congress. (2008). LC Acquisitions and Bibliographic Access Directorate, Program for Cooperative Cataloging Statistics. Cataloging and Acquisitions Homes. Retrieved from http://www.loc.gov/catdir/pcc/stats/FY2008/intco_my08.pdf

Library of Congress. (2009). LC Acquisitions and Bibliographic Access Directorate, Program for Cooperative Cataloging Statistics: NACO/BIBCO/CONSER/SACO, 1-3. Cataloging and Acquisitions Homes. Retrieved from http://www.loc.gov/catdir/pcc/stats/FY2009/funstats09m.pdf

Library of Congress. (2007). MARC 21 Specifications for Record Structure, Character Sets, and Exchange Media, Character Sets and Encoding Options. Retrieved from http://www.loc.gov/marc/specifications/speccharintro.html

Library of Congress (2007). White Paper: Issues Related to Non-Latin Characters in Name Authority Records. Cataloging and Acquisitions Homes. Retrieved from http://www.loc.gov/catdir/cpso/nonlatin.pdf

Library of Congress (2005). Statement of International Cataloguing Principles, Draft approved by the IFLA Meeting of Experts on an International Cataloguing Codes, $1^{\text {st }}$, Frankfurt, Germany, 2003. Retrieved from http://www.loc.gov/loc/ifla/imeicc/source/statement-draft_jan05.pdf

Library Technology Guides (2009). Ex Libris News. Key Resources in the Field of Library Automation. Retrieved from http://www.librarytechnology.org/exlibris.pl 
Marais, H. (2004). Authority Control in Academic Library Consortium Using a Union Catalog Maintained by a Central Office for Authority Controi. (Doctoral dissertation). University of South Africa, South Africa.

MARC Kenkyū-kai. (1990). Jinmei tenkyo ni tsuite: JAPAN MARC to TRC MARC, Tokyo: Toshokan Ryūtsū Center.

Matsui, S. (2001). NACO Activity: A Literature Survey. Record of Workshop on Authority Control Among Chinese, Korean and Japanese Languages. Retrieved from http://www.nii.ac.jp/publications/CJK-WS/2-2Matsui.pdf

Melzer, P. (2008). Descriptive Cataloging of East Asian Material: CJK Examples of AACR2 and Library of Congress Rule Interpretations. Cataloging and Acquisitions Homes. Retrieved from http://www.loc.gov/catdir/cpso/CJKIntro2.html

Miura, K. \& Matsui, S. (2001). Ōbei ni okeru choshamei tenkyo fairu no kyōdō sakusei no dōkō [Trends of Shared Construction of Author-Name Authority Files in Europe and North America]. Nihon Toshokan Joho Gakkaihi [Annals of Japan Society of Library Science]. 47(1), 29-41.

Miyazawa, A. (2002). Network of East Asian Library Networks: Feasibility. Workshop on Authority Control among Chinese, Korean and Japanese Languages (CJK Authority 3). Retrieved from http://www.nii.ac.jp/publications/CJK-WS/cjk301a.pdf

Miyazawa, A. (2007). Parallel Writing in East Asian Languages and its Representation in Metadata in Light of the DCMI Abstract Model. International Conference on Dublin Core and Metadata Applications. Retrieved from http://www.dcmipubs.org/ojs/index.php/pubs/article/viewFile/22/13

Moore, J. <julie.renee.moore@gmail.com> (2008, November 29). Re: Cataloging Questions [personal emails].

Morimoto, H. (2002). Cataloging Monographs and Material in Different Formats: Exercises. North American Coordinating Council on Japanese Library Resources, 1-19. Retrieved from http://www.fas.harvard.edu/ ncc/workbook/pdf/catalogingmonographsandmateria 1.pdf 
Morimoto, H. (2006). JTKU Bibliographic Records Loaded in RLG Union Catalog: Their Compatibility with LC Practices for Japanese-Language Monographic Title Cataloguing. IFLA Satellite Meeting, Scholarly Information on East Asia in the 21st Century, IFLA General Conference. Retrieved from http://ohmyvocabulary.com/ifla/HideyukiMorimoto.rtf

Morimoto, H. (2005). NII Webcat Plus no Kita-Amerika Chiiki deno Yuyōsei: Kensaku oyobi Kiban to naru Shoshi Record no Kanten yori [Utility of NII Webcat Plus in North America: Retrieval and Idiosyncrasies of Webcat Plus Bibliographic Records]. Daigaku Toshokan Kenkyü,74, 19-27.

Mugridge, R. L. \& Furniss, K. A. (2002). Education for Authority Control Whose Responsibility Is It? Cataloging \& Classification Quarterly, 34(1/2), 231-241.

Naitō, E. (2004). Names of the Far East: Japanese, Chinese, and Korean Authority Control. Cataloging \& Classification Quarterly, 38(3/4), 251-268.

Niimoto, K. (2004). OCLC and Libraries in Japan. OCLC Members Council. Retrieved from www.oclc.org/memberscouncil/meetings/2005/october/niimoto.ppt

OCLC. (1995). OCLC to Convert 209,000 East Asian Titles. Information Today, 12(10), 4

OCLC. (2009). OCLC Annual Report, 2007/2008. Retrieved from http://www.oclc.org/news/publications/annualreports/2008/2008.pdf

OCLC. (1998). OCLC CJK Users Group and OCLC CJK Users Group Program Committee. East Asian Studies Electronic Data-files. Asian Libraries, 7(9), 215218.

OCLC. (2007). OCLC Connexion Client: Non-Latin Script Cataloging. An OCLC Tutorial. Retrieved from http://www5.oclc.org/downloads/tutorials/connexion/client/nonlatin.html

OCLC. (2009). TRC Library Services Now Adding Records to WorldCat. News and Events. Retrieved from http://www.oclc.org/news/announcements/announcement273.htm

OCLC, Character Sets, 5:1-5:12. WorldCat and Cataloging documentation. Retrieved from http://www.oclc.org/support/documentation/worldcat/records/subscription/5/5.pdf 
OCLC. (2003). Technical Bulletin, 250. WorldCat and Cataloging documentation. Retrieved from http://www.oclc.org/support/documentation/worldcat/tb/250/250.pdf

Ogawa, Y. \& Matsuda, T. (1999). Overlapping statistical segmentation for effective indexing of Japanese tex. Information Processing \& Management, 35(4), 463480 .

Ozawa, N. (2001). Comparison of Authority Data. $2^{\text {nd }}$ Workshop on Authority Control among Chinese, Korean, and Japanese Languages, 191-217.

Pickard, J. A. (2007). Research Methods in Information. London: Facet Publishing.

Plassard, M. (2001). Authority Control in an International Environment: the UNIMARC Format for Authorities. Rec Work Auth Control Chin Korean Jpn Lang, 105-126.

Porta, A. D. (2005). Planning for Unicode in Libraries: the LC Perspective. SLA Annual Conference. Retrieved from http://www.loc.gov/ils/UNICODE/Unicode@SLA.pdf

Reimer, J. J. \& Morgenroth, K. (1993). Hang Together or Hang Separately: The Cooperative Authority Work Component of NACO. Cataloging \& Classification Quarterly, 17(3/4), 127-161.

Saffady, W. (1999). Introduction to Automation for Librarians. Chicago: American Library Association.

Sakai, K. \& Kyoto, T. (2001). NACSIS-CAT Author Name Authority Data. $2^{\text {nd }}$ Workshop on Authority Control among Chinese, Korean, and Japanese Languages, 226-249.

Sakamoto, H. (2004). Kokuritsu Toshokan no "Kuni no Meisho Tenkyo Control" Keikaku [National name authority control plan of National Diet Library]. Retrieved from http://www.sousei.gscc.osakacu.ac.jp/ws/wspdf/media/m041209.pdf

Sanchez, E. (2007). Emerging Issues in Academic Library Cataloging \& Technical Services. New York: Primary Research Group.

Sauperl, A. (1999). Subject Determination During the Cataloging Process (Doctoral dissertation). University of North Carolina at Chapel Hill, North Carolina.

Saur, K.G. (1987). Automated Systems for Access to Multilingual and Multiscript Library Materials, Problems and Solutions. New York: IFLA-Publications, 38. 
Schiff, A. (2009). Non-Latin Script References in Name Authority Records. Cataloging and Acquisitions Homes. Retrieved from http://www.loc.gov/catdir/pcc/naco/NonLatin $\% 20$ Script $\% 20$ References $\% 20 \mathrm{in} \% 20$ Name $\% 20$ Authority $\% 20$ RecordsRevJune2009.ppt

Shimada, T. (2005). Feature Article: ILL: the Japanese Perspective. Ontario Council of University Libraries: ILL Newsletter. 1(2), 1-10. Retrieved from http:/www.scholarsportal.info/vdx/support/project-info/newsletter/december05.pdf

Shōji, M. (2002). Utilizing Japanese Bibliographic Data. Paper Presented at the $30^{\text {th }}$ Annual Hong Kong Innovative Users Group (HKIUG) Meeting, Hong Kong.

Starck, W. L. \& Ryn, V. P. (Eds.). (2005). NACO Participants' Manual (3 ${ }^{\text {rd }}$ ed.). Washington, DC: Library of Congress. Retrieved from http://www.loc.gov/catdir/pcc/naco/npm3rd.pdf

Sugimoto, S., Lee, W., Zhao, Q., Nagamori, M., Sakaguchi, T., \& Tabata, K. (2002). An Experimental Study on a Collaborative Development of a Multilingual Subject Gateway for Public Library Users. International Conference on Dublin Core and Metadata Applications, Proceedings of the 2003 International Conference on Dublin Core and Metadata Applications: Supporting Communities of Discourse and Practice - Metadata Research \& Applications, Beijing, China.118-130.

Takawashi, T. (2002). Cataloging in Japan: Relationship Between Japanese and Western Cataloging Rules. Cataloging \& Classification Quarterly, 35(1/2), 209-225.

Tartaglia, S. (2004). Authority Control and Subject Indexing Languages. Cataloging \& Classification Quarterly, 39(1/2), 365-377.

Taylor, A. G. (2004). Teaching Authority Control. Cataloging \& Classification Quarterly, 38(3), 43-57.

Tillett, B. B. (2002). A Virtual International Authority File. Workshop on Authority Control Among Chinese, Korean, and Japanese Languages (CJK Authority 3). Retrieved from http://www.nii.ac.jp/publications/CJK-WS/cjk3-08a.pdf

Toshokan Ryūtsu Center (TRC). (2009). TRC MARC, Reference Tool. Retrieved from http://www.trc.co.jp/library/tool/marc_3_01.html

Wang, D. (2005). Vernacular Searching and Retrieval in OCLC Connexion Client. Journal of East Asian Libraries, 137, 65-88. 
Wei, K. (2007, March). Looking to the Future: CJK Processing at the Crossroads. Paper Presented at the 2007 CEAL Committee on Technical Processing, Boston.

Wei, K., Harrison, S.E., \& Kim, J. (1998). East Asian Studies Electronic Datafiles. Asian Libraries, 7(9), 215-218.

Ward, J. H. (2009). Notes on Operations, Acquisitions Globalized: The Foreign Language Acquisitions Experience in a Research Library. Library Resources and Technical Services, 53(2), 86-93.

Wu, J. (2006). Essential Democracy in Action-Cooperative Cataloging of East Asian Material. Paper presented at the Scholarly Information on East Asia in the $21^{\text {st }}$ Century, IFLA Satellite Meeting in Conjunction with WLIC Seoul, Seoul. Retrieved from http://ohmyvocabulary.com/ifla/JipingWu.doc

Yang, A. (2008). Updates on Descriptive Cataloging of East Asian Material: CJK Examples of AACR2-Chapter 12, CEAL Conference. Committee on Technical Processing, Serial Committee. Retrieved from http://www.eastasianlib.org/ctp/cealctp08/2008CEAL-Yang.ppt

Yoshida, C. (2000). Sōgo mokuroku database no hinshitsu kanri ni tsuite no kōsatsu OCLC to no hikaku o tōōshite [Reconsidering the Quality and Maloging Database-based on the Comparison with OCLC]. Tosho no fu: Meiji daigaku toshokan kiyō [Meiji University Library Journal], 4, 1-17.

Yu, A. J. (1999). The Future of Authority Control for CJK Name Headings. Journal of the Hong Kong Library Association, 19, 79-86.

Zhuo, F., Emanuel, J., \& Jiao, S. (2007). International Students and Language Preferences in Library Database Use. Technical Services Quarterly, 24(4), 1-13.

Zhu, L., \& Seggern, M. V. (2005). Vendor-Supplied Authority Control: Some Realistic Expectations. Technical Services Quarterly, 23(2), 49-65. 


\section{Appendix: Questionnaire on Cataloging for CJK Library Materials}

Question 1-1 (for Chinese materials).

How many FTE professional cataloger specialized in Chinese materials does your library have?

- 0.5

- 1

- 1.5

- 2

- 2.5

- 3

- Other:

Question 1-2 (for Japanese materials).

How many FTE professional cataloger specialized in Japanese materials does your library have?

- 0.5

- 1

- 1.5

- 2

- 2.5

- 3

- Other: 
Question 1-3 (for Korean materials).

How many FTE professional cataloger specialized in Korean materials does your library have?

- 0.5

- 1

- 1.5

- 2

- 2.5

- 3

- Other:

Question 2-1 (for Chinese materials).

How many FTE para-professional catalogers (or library assistants) for Chinese materials does your library have?

- 0.5

- 1

- 1.5

- 2

- 2.5

- 3

- Other: 
Question 2-2 (for Japanese materials).

How many FTE para-professional catalogers (or library assistants) for Japanese materials does your library have?

- 0.5

- 1

- 1.5

- 2

- 2.5

- 3

- Other:

Question 2-3 (for Korean materials).

How many FTE para-professional catalogers (or library assistants) for Korean materials does your library have?

- 0.5

- 1

- 1.5

- 2

- 2.5

- 3

- Other: 
Question 3.

Do you use OCLC Connexion as a copy cataloging tool?

- Yes

- No

- Other:

Question 4.

Which national level bibliographic databases do you check first when searching the title?

- OCLC Connexion

- LC Catalog

- Other:

Question 5.

If your library uses outsourced cataloging vendor (s) for your CJK monographs, are they located in the U.S. or East Asian countries (China, Japan, or Korea)?

- U.S.

- East Asian countries

- Both

- Other: 
Question 6.

What was the major challenging for CJK cataloging when you have transited from RLIN to OCLC?

Question 7.

Does your library purchase from your outsourced cataloging vendor shelf-ready service?

- Yes

- No

- Other:

Question 8.

What do you think about the benefit of outsourced cataloging? Please check all that apply.

- Cost-effective

- To increase the speed of cataloging process

- Better quality of cataloging

- Other:

Question 9.

Are your bibliographic records updated by in-house cataloging staff or outsourced?

- In-house

- Outsourced 
- Both

- None

- Other:

Question 10.

Are the authority records maintained in-house cataloging staff or outsourced?

- In-house

- Outsourced

- Both

- None

- Other:

Question 11.

How do you manage your backlogged CJK materials?

- In-house

- Outsourced

- Both

- None

- Other:

Question 12.

Do you have any cataloging training (e.g. workshop) available for CJK materials?

- Yes

- No 
- Other:

Question 13.

Does your library OPAC have the feature (input/display) CJK vernacular script search?

- Yes

- No

- Other:

Question 14.

Which model (Model A or Model B) is used for your MARC 21 bibliographic records in CJK language materials?

- Model A

- Model B

- Other: 


\section{Question 15.}

Is your library a member of CJK NACO? (If your answer is "NO," please proceed to the question 15.)

- Yes

- No

- Other:

Question 16.

If your answer is "Yes" on Question 13, how many year (s) has your library been in a member?

- 1 year

- 2 years

- 3 years

- Other:

Question 17.

If your answer is "No" on Question .13, are you currently planning to become a member within two years?

- Yes

- No

- Do not know 
Question 18-1 (Chinese).

What is your language proficiency level (reading, writing, and speaking) in each CJK? Please use the following scale criteria. Scale 1: Elementary proficiency, Scale 2: Limited Woking proficiency, Scale 3: Professional Working proficiency, Scale 4: Full Professional proficiency, Scale 5: Native or Bilingual proficiency

\begin{tabular}{|l|l|l|l|l|l|}
\hline & 1 & 2 & 3 & 4 & 5 \\
\hline Chinese & & & & & \\
\hline
\end{tabular}

Question 18-2 (Japanese).

What is your language proficiency level (reading, writing, and speaking) in each CJK? Please use the following scale criteria. Scale 1: Elementary proficiency, Scale 2: Limited Woking proficiency, Scale 3: Professional Working proficiency, Scale 4: Full Professional proficiency, Scale 5: Native or Bilingual proficiency

\begin{tabular}{|l|l|l|l|l|l|}
\hline & 1 & 2 & 3 & 4 & 5 \\
\hline Japanese & & & & & \\
\hline
\end{tabular}

Question 18-3 (Korean).

What is your language proficiency level (reading, writing, and speaking) in each CJK? Please use the following scale criteria. Scale 1: Elementary proficiency, Scale 2: Limited Woking proficiency, Scale 3: Professional Working proficiency, Scale 4: Full Professional proficiency, Scale 5: Native or Bilingual proficiency 


\begin{tabular}{|l|l|l|l|l|l|}
\hline & 1 & 2 & 3 & 4 & 5 \\
\hline Korean & & $\cdot$ & & & \\
\hline
\end{tabular}

Question 19.

Please select all the cataloging activities for CJK library materials you use from the following list.

- Identify bibliographic elements

- Determine main topics for creating subject headings

- Read bibliographic data

- Other:

Question 20.

Have you taken any training and/or read the draft of RDA

http://www.rdaonline.org/constituencyreview/?

- Yes

- No

- Other:

Question 21.

What changes are coming to cataloging and how to the cataloging department meet them? 
Question 22.

Would you like to make any other comments? 